\title{
ENVIRONMENTAL MONITORING REPORT FOR CALENDAR YEAR 1986
}

\author{
Joseph R. Stencel \\ Plasma Physics Laboratory, Princeton University \\ Princeton, New Jersey 08544
}

\begin{abstract}
The results of the 1986 environmental monitoring program for the Princeton Plasma Physics Laboratory (PPPL) are presented and discussed. Two of three large tokamak machines, the Princeton Large Torus (PLT) and the Tokamak Fusion Test Reactor (TFTR) were in operation during the year. The Princeton Beta Experiment (PBX) was shut down in December 1985 to undergo major modifications, and will recommence operations in 1987. PLT was shut down in December 1986. In addition, the S-1 Spheromak and the Radio-Frequency Test Facility (RFTF) were operated on a limited basis in 1986.

The Environmental Committee became a standing committee of the Executive Safety Board (ESB) and continued to review items of environmental importance. During CY86 no adverse effects to the environment or public resulted from any operational program activities at PPPL, and the Laboratory was in compliance with all applicable FederaI, State, and local environmental regulations.
\end{abstract}

\section{DISCI.AIMER}

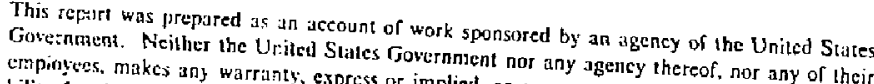
bility for the accufacy, completeness, or uselulness or assumes any legal liability or responsiprocess uisclosed, or represents that its use wolness of any information, apparatus, product, or ence hercin to any specific commercial pareduct nol infringe privately owned rights. Refer. manufucturer, or otherwise foes not producl. process, or service by arade name, trademark, mendation, or favoring by the United Stesty conslitute of imply its endorsement, recomand opinions of ajthors expressed herein do hovernmest or any agency thereor. The views Unilcd Siales Government or any agency thereof. necessarily state or reflect those of the
}

\section{MASTER}




\section{TABLE OF CONTENTS}
Abstract
$\underset{i}{\text { Page }}$
Table of Contents ....................................................................................... ii
List of Tables and Figures ......................................................................... iv

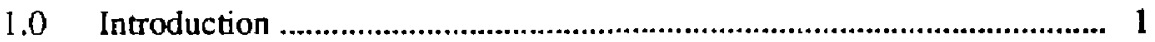

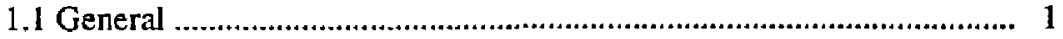

1.2 Description of the Site ............................................................ 4

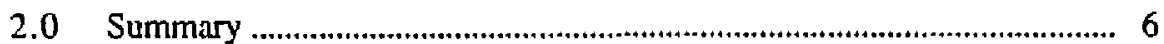

3.0 Monftoring, Environmental Program Information,

Data Collection, Analyses, and Evaluation ...................................... 7

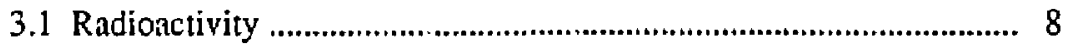

3.1.1 Penetrating Radiation ........................................................ 8

3.1.2 Special Surveys ..................................................................... 9

3.1.3 Airborne Radioactivity ....................................................... 10

3.1.4 Waterbome Radioactivity ................................................ 11

3.1.5 Foodstuffs ............................................................................ 12

3.1.6 Soil, Grass, Vegetation ............................................................. 12

3.2 Nonradioactive Pollutants ...................................................... 12

3.2.1 Airborne Effluents ........................................................... 12

3.2.2 Water Utilization ............................................................... 13

3.2.3 Spills ........................................................................................... 15

3.2.4 Herbicides, Fertilizer, and Pesticides .............................. 15

3.2.5 Polychlorinated Biphenyls ............................................. 15

3.2.6 Hazardous Waste ......................................................... 16

3.3 Environmental Impact ........................................................... 16

3.3.1 Assessment of Radiation Dose to the Public ................ 16

3.3.2 Assessment of Nonradioactive Pollutants .................... 17

4.0 Quality Assurance for Laboratory Analyses ............................. 17 
iii

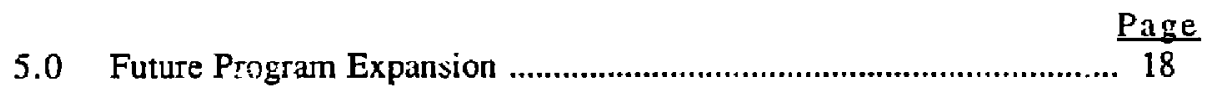

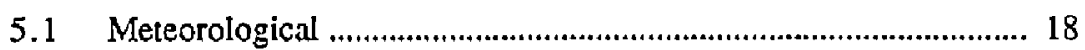

5.2 Water Quality ..................................................................... 18

5.3 Radioactive Effluents ..................................................... 19

5.4 Nonradioactive Effluents ........................................... 19

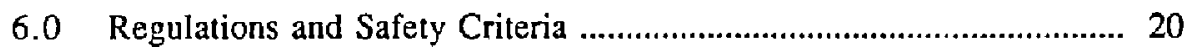

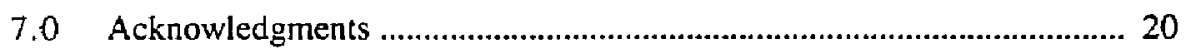

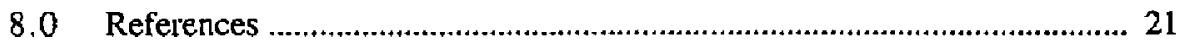


Table $\mathrm{J}$

Table 2

Table 3

Table 4-13A

Table 14-26

Table 27

Table 28

Table 29
TFTR Radiation Exposure Criteria ............................. 24

Critical Pathways ............................................................ 25

Monitoring Program Covering Critical Pathways . 26

Demographics ................................................................. 27

Water Quality Monitoring Data (Nonradioactive).. 38

Nonradioactive QA Results ........................................... 61

QA/QC Tritium Cross Check Data ................................ 62

Fertilizer, Pesticide, Herbicide Application ........... 63

\section{LIST OF FIGURES}

Figure 1

Figure 2

Figure 3

Figure 4

Figure 5

Figure 6

Figure 7

Figure 8

Figure 9

Figure 10

Figure 11

Figure 12

Figure 13

Figure 14

Figure 15
The Spheromak S-1

The Radio-Frequency Test Facility

The Princeton Large Torus

The Princeton Beta Experiment

The Tokamak Fusion Test Reactor

Wind Rose Data 1984-86 (30 m)

Wind Rose Data $1984-86(60 \mathrm{~m})$

$80-\mathrm{km}$ (50 mile) Radius Of Site

5-Mile Radius Of Site

PPPL Site

1974 10-Mile Population Estimates

1985 10-Mile Population Estimates

64

65

66

67

68

69

70

71

72

C \& D Site Monitoring Stations

Off-Site Surface Water Monitoring Stations 77

Off-Site Soil, Planned Air Monitoring Locations.... 78 


\subsection{INTRODUCTION}

\subsection{General}

This report gives the results of the environmental monitoring program at the Princeton Plasma Physics Laboratory (PPPL) for Calendar Year 1986 (CY86). The report is prepared to provide the U.S. Department of Energy (DOE) and the public with information on the level of radioactive and nonradioactive pollutants, if any, added to the environment as a result of PPPL operations. The objective of the environmental monitoring report is to document evidence that DOE facility environmental protection programs adequately protect the environment and the public health.

PPPL has engaged in fusion energy research since 1951 and in CY86 had two of its three large tokamak devices in operation; namely, the Princeton Large Torus (PLT) and the Tokamak Fusion Test Reactor (TFTR). The Princeton Beta Experiment (PBX) was shut down at the end of 1985 to undergo a major modification (PBX-M), and should be back in operation in June 1987. In addition, the S-1 Spheromak, which began operation in CY83, after upgrades to the flux core liner, has continued on a program of plasma research operation. The goal of the Magnetic Fusion Energy Research Program is to develop and demonstrate the practical application of fusion power as an alternate energy source.

The Spheromak is a compact toroidal concept. The S-1 (Fig. 1) achieved an initial goal of producing hot $(100 \mathrm{eV})$ plasmas with a lifetime of $1 \mathrm{msec}$ or more in 1985. With the achievement of toroidal currents of over $300 \mathrm{kA}$, electron densities in the midto-upper $10^{13} \mathrm{~cm}^{-3}$ range, operating currents over $500 \mathrm{kA}$, and with the new flux core liner installed, the future looks good for producing electron temperatures in the $200-300 \mathrm{eV}$ range. A new current transformer, if the budget allows, will be installed to increase the plasma current into the $1 \mathrm{MA}$ range. Operation and maintenance of the S-I has no expected potential for impact 
on the environment, a conclusion that is documented in the project's Safety Assessment Document (El84).

Another small device, the Radio-Frequency Test Facility (RFTF) began operation in CY84 (Fig. 2). RF wave launcher testing for boih PLT and TFTR operations were undertaken in 1985 and continued in 1986. In addition, feasibility studies were done on the use of plasma arcs to disassociate chemical compounds. The conclusion of the RFTF Safety Assessment Document was that the device will have no effect on the environment (Na84). This has proven to be the case in operations to date. If funding is obtained to increase the research on spin-off technologies, such as disassociating hazardous compounds, a new assessment will be initiated.

The PLT (Fig. 3) had another successful year of research in RF heating techniques. After 12 years of operation the PLT was shut down in December 1986, and for the immediate future will remain mothballed. The PLT had no effect on the environment.

The PBX (Fig. 4), after achieving a $>5 \%$ beta (ratio of plasma pressure/magnetic pressure) in CY84 experiments, was shui down at the end of 1985 to undergo modifications to further examine theoretical predictions on plasma shaping. The addition of new coils within the ressel, new power supplies. and a new control system began in 1986 . The modified device (PBX-M) is expected to be back in operation in June 1987. A Safety Assessment Document (SAD) was published for the PBX in 1984 (F184) which indicated that the PBX did not pose any potential environmental concerns. A new SAD will be published for the PBX-M and initial indications are that the device should not pose any environmental concerns.

The TFTR (Fig. 5) which had its first full year of operation in CY83, increased the total neutron production in CY86 to $2.4 \mathrm{x}$ 1018. The increased neutron production increased the activation jevel of the machine to the point where health physics surveys were required in the test cell following a machine run before 
entry was allowed for inspection, routine maintenance, or installation work. The TFTR is a toroidal device in which a deuterium-tritium (D-T) plasma will be magnetically confined and heated to extremely high temperatures by neutral beam injectors. D-T operations are presently scheduled for 1990 . Ion Cyclotron Radio-Frequency (ICRF) heating is expected to be operational in 1988. A major achievement in 1986 was an increase in neutron production and power by operating in what is now called the "supershot" pulse mode. Using this teshnique a new record temperature of $>200$ million degrees Celsius was achieved. The potential hazards of this program are addressed in Safety Analysis Reports for the Project (PSAR78 and FSAR82). The FSAR is being updated to reflect tritium operation.

The PPPL site is, in general, open to the public. This free access has necessitated a thorough evaluation of the on-site discharges as well as the potential for off-site releases of radioactive and toxic nonradioactive effluents. An extensive monitoring program tailored to these needs has been instituted and expanded over recent years. The PPPL radiological environmental monitoring program generally follows the gutance given in two DOE reports, namely A Guide for: Environmental Radiological Surveillance at U.S. Department of Energy Installations (Co81) ard Environmental Dose Assessment Methods for Normal Sperarions at DOE Nuclear Sites (PNL-4410) (St82). This includes adherence to the standards given in DOE Orders, in particular, DOE Order 5480.1A, Chapter XI (DOE81), which pertains to permissible doses and concentration guides, and gives guidance on maintaining exposures "to as low as reasonably achievable" (ALARA). Additional interim criteria were forwarded by memo (Mi85) and are expected to become an official part of the Order in the future. Specifis criteria for implementing these standards on TFTR are contained in a TFTR Operational Safety Requirement (OSR/TFTR/0-2F-C) (see Table 1). This table was undated in 1986 to include the EPA airborne emission reauirements.

The emphasis of the monitoring program has been placed on 
exposure pathways appropriate to fusion energy projects. These pathways include external exposure from direct penetrating radiation and eventually from airborne radionuclides, such as ${ }^{41} \mathrm{Ar}, 13 \mathrm{~N}, 16_{\mathrm{N}}$, and internal exposure from radionuclides, such as $3 \mathrm{H}$ in air anci water. Seven major critical pathways were considered (see Table 2). Prompt radiation was also considered and is being measured. The monitoring program as envisioned by the TFTR. Final Safety Analysis Report (FSAR82) has been updated to reflest the current environment around TFTR (see Table 2). At present, the radioactive pollutant potential to the environment by any pathway is essentially nonexistent. Small amounts of tritium produced from D-D reactions (approximately $100 \mathrm{mCi}$ total in 1986 if all neutrons were D-D produced) are not measurable outside the TFTR facility. Low levels of tritium (exempt quantities) are now detectable in pump oils.

Preliminary meteorological considerations and associated methodology, which were established at the time of the installation of FPPL's first meteorological tower, were reported in Section 2 of the TFTR FSAR. Subsequently, improved methodologies were implemented and a new meteorological tower was erected and began operation in November 1983 (Mc83). The improved measurements and methodologies will be included in the updated FSAR being prepared for tritium operations. Data have been collected for three years using the monitors on the new tower. Wind rose plots from the data for these three years (1984-86) are shown in Figs. 6 and 7.

\subsection{Description of the Site}

PPPL is located at the James Forrestal Research Campus of Princeton University. As shown in Fig. 8, the location is in central New Jersey within Middlesex County. The site has undisturbed areas with virgin forest, open grass areas, an airplane runway, and a small brook (Bee Brook) running through its eastern boundary. The closest urban centers are New Brunswick, 14 miles to the northeast and Trenton, 12 miles to the southwest. Major metropolitan areas including New York 
City, Philadelphia, and Newark are within 50 miles of the site. As shown in Fig. 9, the municipalities of Princeton, Plainsboro, Kingston, Penns Neck, Princeton Junction, and Cranbury, among others, are in the immediate vicinity of the site. Also, the main campus of Princeton University, Iocated primarily within the borough of Princeton is approximately three miles to the west of the site. The general layout of the faciiities at the Forrestal Campus is indicated in Fig. 10, where the specific location of TFTR is denoted as D-site.

Figure 11 and Table 4 indicate the 1974 population estimates in sectors within ten miles of PPPL. Table 5 and Fig. 12 show the projected population for 1985. This was derived by the New Jersey State Office of Business Economics in the Department of Labor and Industry which calculated the percentage increase projected for municipalities in the zero-to-ten-mile region. The resident population within 10 to 50 miles of PPPL, based on the 1970 census, is shown in Table 6. The site is in the center of a highly urbanized region extending from Boston, Massachusetts to Washington, D.C. The 1985 population projections for the States of New Jersey, New York, and Pennsylvania indicate a substantial population increase within 50 miles of the PPPL site. The actual change from 1970 to 1980, as indicated by the census in these two years, was not as large as expected. In fact, the population in New York City and Philadelphia decreased. The Princeton area continues to experience a substantial increase in new business moving into the Route 1 corridor near the site. The increase, however, has not been as great as the projections had indicated. Because of delays in the tritium program, a new demographic study was delayed. The Compact Ignition Tokamak (CIT) has a new demographic study underway and these data will be utilized in the CY87 report. An internal study on population distribution was done in 1985 (St85), but was not expanded to cover the detail of annular regions and sectors (see Tables 7-13). A sectorized population data summary was prepared in 1986 for use with several standard codes used for the determination of off-site dose due to the release of airborne activated nuclides and tritium (Ko86b). Table 13A shows data 
suppiied by the Princeton Forrestal Center on the number of workers within one mile of the TFTR site. This number was divided by 4 to cbtain an equivalent exposure for habitation (Ko86b).

\subsection{SUMMARY}

During CY86 there were no accidents, incidents, or occurrences that had an impact on PPPL facilities, program operations, or the environment. A spill from a barrel of Freon-113 required the disposal of 13 cubic yards of dirt in the cleanup process (Sr86). Written procedures were initiated and implemented by the Environmental Committee to assign organizational responsibilities during a spill. Weed control and grass fertilization were applied under the direction of the Princeton University Buildings and Grounds Department. The work was done by University personnel or certified contractors in accordance with EPA regulations. Transformers and capacitors containing PCB oils are being removed from service and disposed of in accordance with prepared schedules and EPA regulations. The Laboratory has a frogram to monitor, inventory, and dispose of $\mathrm{PCB}$ and other potentially toxic materials.

Surface water analyses for both radioactive and nonradioactive pollutants have not shown anything above normally expected background values. The initial phase of a program for ground water analysis was initiated in 1985. The US Geological Service (USGS) finished their drilling programs in 1986, but continue to monitor a tracer test initiated in the fall of 1986. Tritium levels slightly less than $100 \mathrm{pCi} / \mathrm{l}(3.7 \mathrm{~Bq} / \mathrm{l})$ have been detected. These data are in agreement with the old on-site drinking water wells and surface water measurements. Soil and vegetation samples were collected and analyzed as part of the baseline studies.

Radiation exposure via airborne effluents into the environment is still at a concentration that is too low to be measurable under present operations. Prompt radiation is detectable at extremely 
low levels during high power pulses from TFTR. The integrated ievol at the Exclusion Zone Boundary (EZB) around TFTR, from TFrP. operations, was less than $1 \mathrm{mrem}(0.01 \mathrm{mSv})$ for CY86 (Gis̄).

Off-site surface water, soils, and biota were analyzed for tadioactive baselines in CY86. In addition, negotiations were initiated for the placement of air, particulate, and passive tritium air monitors. These inonitors were tested in 1986 and are expected to be placed in the field in the summer of 1997.

\subsection{MONITORING, ENVIRONMENTAL PROGRAM INFORMATION, DATA COLLECTION, ANALYSES, AND EVALUATION}

The monitoring program implementation has followed a phased approach commensurate with the potential hazards and the needs of an expanding program. Nonradioactive water pollutant. monitoring has been conducted for many years. A more extensive program, which begar in 1979, presently includes eight surface water sampling points (four on-site and fcur offsite), four ground water sites (two old drinking water wells and two new wells near the TFTR liquid effluent tanks), and the potable water supply source. Monitoring for sources of potential radiological exposures is quite extensive Real-time prompt gamma/neutron environmental monitorirg began on the TFTR site in 1981 to establish baselines prior to machine operation. The original station (RMS-B), located on the TFTR site, was discontinued in 1986 but data from the many other stations had been seen to correlate well. The area was vacated for TFTR ICRF needs and future CIT facilities. Four monitoring stations are located at the TFTR EZB. Neutron monitors ware added at these Iocations at the end of CY84. Passive tritium monitors will be added in CY87 Radiological water samples are being collected at the same locations as the nonradioactive sample points (see Figs. 13 and 14). Soil and biota samples are also being analyzed for tritium baselines. Iodise, cesium $m_{\S}$ and ruthenium from the 
Soviet reactor accident in Chernobyl were easily detected during May 1986; however, levels were low and no significant impact on the environment on or around the PPPL site resulted from this accident.

\subsection{Radicactivity}

\subsubsection{Peneitating Radiation}

Operation of the Princeton Large Torus (PLT) and the Princeton Beta Experiment (PBX) results in the production of some penetrating radiation (primarily bremsstrahlung $X$ rays and neutrons). Because neither the PLT or PBX have a roof shield, skyshine radiation (primarily neutron) is seen at the TFTR EZB site monitoring stations. The shielding installed for the PLT/PBX machines has kept the total exposure dose equivalents in occupied areas below occupational exposure guidelines. Skyshine radiation from the neutron production by PLT added less than 1 mrem to the D-site environs. PBX was not operating in 1986, but the overall site boundary radiation from all devices was less than 1 mrem ( $0.01 \mathrm{mSv}$ ) (Gi87).

The stated Laboratory Policy is that when occupational exposures have the potential to exceed $1000 \mathrm{mrem} / \mathrm{yr}$ (10 $\mathrm{mSv} / \mathrm{yr}$ ), the appropriate project manager must petition the PPPL Executive Safety Board (ESB) for an exemption, In addition, the Laboratory applies the DOE ALARA policy to all its operations. This philosophy for occupational exposure means that environmental radiation levels, as a result of experimental device operation, are also very low, and acceptable.

The design objective for TFTR is to stay below $10 \mathrm{mrem} / \mathrm{yr}(0.1$ $\mathrm{mSv} / \mathrm{yr}$ ) above natural background from all sources of radiation at 125 meters from the machine, i.e., the EZB. The TFTR, like other tokamaks, produces bremsstrahlung radiation from the electrons striking internal hardware at the end of a pulse. These $X$ rays, in the range of 0 to $20 \mathrm{MeV}$, also produce photoneutrons. Injection of deuterium neutral beams began at the end of CY84. 
With these D-D runs the neutron fluxes have increased each year as the neutral beam heating power increased. In CY85 the neutron production was on the order of $5 \times 10^{16}$ for the entire year. This number increased to $2.4 \times 10^{18}$ in CY86. Additional shielding was added to the TFTR test cell walls in the middle of CY85. This added shielding prevented any significant penetrating radiation from being added to the environs due to TFTR operations in 1986. Radiation levels (UR) were recorded for some pulses outside the test cell, with the total exposure dose equivalent at the TFTR EZB being less than $1 \mathrm{mrem}(0.01 \mathrm{mSv})$ for CY86 (Gi87).

The TFTR real-time site boundary monitors are Reuter-Stokes Sentri 1011 pressurized ionization chambers and He-3moderated neutron detectors. The electronics in the ionization chambers were modified to allow the integration of any prompt radiation resulting from a TFTR machine pulse that may be above natural background. These data are stored and processed as part of the Central Instrumentation Control and Data Acquisition (CICADA) computer system. Four of these monitoring stations are placed at the EZB (125 meters from the TFTR) (see Fig. 13). Another eight ionization chambers of lower sensitivity and neutron monitors are located nearer the TFTR device (four outside the test cell wall, three in the basement, and one on the roof). These eight detector locations are for personnel safety and are not considered environmental detectors per se. However, data collected from these monitors are used to help correlate environmental measurements. Besides the moderated He-3 neutron detectors, Bonner-type-moderated $\mathrm{Li}(\mathrm{I})$ detectors were used for monitoring at various locations throughout the TFTR facility.

\subsubsection{Special Surveys_(St81)}

In August 1980, EG\&G, Inc., under DOE contract conducted an aerial radiological survey of PPPL and surrounding areas. The detection system consisted of 20 sodium iodide detectors, a multichannel analyzer, and a magnetic tape recording system. 
The nominal exposure rate range observed was 8 to $10 \mathrm{uR} / \mathrm{h}$. Detected radioisotopes were consistent with normal background emitters. Since conditions have not changed since 1980, there is no need at this time to i-peat the survey.

\subsubsection{Airborne Radioactivity}

Radioactivation of air and tritium in measurable cencentrations is not expected until TFTR D-T operations. A silica gel environmental tritium monitor (Gr86) was tested in 1986, and will be placed in the field by the summer of 1987. Based on D-D neutron production during CY86, it is estimated that approximately $100 \mathrm{mCi}(3.7 \mathrm{GBq})$ of tritium could have been added to the environs outside the TFTR facility. This is essentially nonmeasurable because it is not produced and released all at once. In comparison, a fission pressurized water reactor releases about $3600 \mathrm{Ci} / \mathrm{yr}$ during normal operation (Nu79). Iodine-131 concentrations duc to the Soviet reactor accident at Chernobyl went from background detection limits $\left(\sim 10^{-14} \mathrm{uCi} / \mathrm{cm}^{3}\right)$ on May $8, i 986$, to $2.5 \times 10^{-12} \mathrm{uCi} / \mathrm{cm}^{3}$ on May 19, 1986, and back to background levels around May 28, 1986.

In November 1983, a three-level, 60 meter tower was installed for gathering meteorological data. Three years worth of data have now been collected. The wind rose data for the first three years of operation are shown in Figs. 6 and 7. Analysis indicates that the site is dominated by neutral to moderate stable conditions with moderately unstable to extremely unstable conditions occurring less than a few percent of the time. Average surface winds are about $2.1 \mathrm{~m} / \mathrm{s}$ and rise to about 4.1 $\mathrm{m} / \mathrm{s}$ at $60 \mathrm{~m}$ (Ko86a). Based on data from this tower, $\mathrm{X} / \mathrm{Q}$ values will be recalculated for the updated FSAR before tritium operation. The data are also being checked for consistency by the Idaho National Engineering Laboratory (INEL) in their preparation of an Environmental Assessment (EA) for the CIT project. 


\subsubsection{Waterborne Radioactivity}

\subsubsection{Surface Water}

Surface water samples at eight locations (four on-site and four off-site) have been analyzed for tritium and photon emitters. Five of these locations have been monitored since CY82. Downstream sampling occurs after mixing of effluent and ambient water is complete. Locations are indicated on Figs. 13 and 14.

Sample analysis has shown no unusual background radionuclides. Tritium analysis by liquid scintillation methods has shown titium values to be less than $100 \mathrm{pCi} / \mathrm{l}(3.7 \mathrm{~Bq} / \mathrm{l})$ on all samples analyzed to date. Tritium enrichment procedures are used on some samples to see lower levels. Rain water samples collected and analyzed ranged from 40 to $140 \mathrm{pCi} / \mathrm{l}$, which was similar to the 1985 range of 45 to $160 \mathrm{pCi} / \mathrm{l}$.

\subsubsection{Ground Water}

Two existing on-site wells (W4 and W5 on C-site) were sampled (see Fig. 13). As a part of continuing efforts to characterize the site, a more comprehensive ground water program was initiated in June 1985 through the U.S. Geological Survey. This program entailed the drilling of several monitoring wells on the TFTR site in order to help profile the ground water system. The final survey report will be available in June 1987. The samples collected from two of the wells (W1 and W10 at D-site) were analyzed for tritium by PPPL and the University of Miami under a USGS sampling program. The split sample results were consistent and indicated tritium levels of slightly less than 100 $\mathrm{pCi} / \mathrm{l}(3.7 \mathrm{~Bq} / \mathrm{l})$. These values are consistent with the results from wells W4 and W5 noted above, as well as the surface water measurements. 


\subsubsection{Drinking Water}

Potable water is supplied by the public utility, Elizabethtown Water Co. In April 1984 a sample point at the input to PPPL was established (E1 location, Fig. 13) to provide baseline data for water coming onto the site. Radioactive analysis has included gamma spectroscopy and tritium.

\subsubsection{Foodstuffs}

Because there are so few dairy farms in this area, milk is not a viable analysis medium around the site. Also the fish population is very scarce or nonexistent in Ditch 5 and Bee Brook, which carry the runoff from the site. DOE has agreed that a substitute of vegetables and other biota from the surrounding area can be used. Sampling in 1986 indicated tritium levels below $100 \mathrm{pCi} / \mathrm{l}$ (3.7 Bq/1) (Gi87).

\subsubsection{Soil, Grass, Vegetation}

Off-site sample locations were established in late 1985 (see Fig. 15). Soil and grass samples collected on-site and off-site in 1986 indicated tritium levels below $100 \mathrm{pCi} / 1(3.7 \mathrm{~Bq} / \mathrm{l})$. Laboratory techniques for doing these analyses were perfected in CY84 (Gr85) and the techniques are documented in the Radiological Environmental Monitoring Laboratory Handbook (REML86). These baselines are being es:ablished since surface soils and vegetation are among the best indicators of tritium after a release (Jo74), (Mu77), (Mu82).

\subsection{Nonradioactive Pollutants}

\subsubsection{Airborne Effluents (Ki87)}

PPPL has a New Jersey Department of Environmental Protection (NJDEP) Permit for its C-site boilers and fuel tank vents. The seven permit certificates numbered 061294 through 061300 , 
were due to expire in March 1987. Application for new permits was initiated in October 1986.

Measurements of actual emissions are not required. Emissions are calculated using formulae supplied by the NJDEP.

\subsubsection{Water Utilization (Ki87)}

\subsubsection{Drinking Water}

Potable water is supplied by the public utility, Elizabethtown Water Co. PPPL used approximately 35 million gallons in CY86. Water quality analysis at the input to PPPL was initiated in CY84 for both radioactive and nonradioactive pollutants (Table 19, E-1 location).

\subsection{2,2 Process (nonpotable) Water}

Nonpotable water is pumped by PPPL from the Delaware $\&$ Raritan Canal as authorized by a permit agreement with the New Jersey Water Supply Authority. This agreement gives PPPL the right to draw up to one million gallons of water per day for process and fire fighting purposes for the period beginning July, 1984 and ending on September 30, 1991. Treatment consists of filtration to remove suspended solids. In 1986 a multimedia sand filter was installed to allow the source of the D-site cooling tower make-up water to be changed from potable water to process water supply. The sampling point (C-1) was established to provide baseline data for process water coming on-site. Table 16 indicates results of water quality analysis at the canal.

\subsubsection{Storm Sewage}

Storm sewage that includes cooling tower and boiler blowdown is discharged into surface waters and is governed at C- and Dsites by NPDES Permit No. NJ0023922 (effective date November 1, 1984 - expiration date October 31, 1989). All process water and most runoff water from $C$ - and $D$-sites now passes through a 
retention basin. Upgrades to the retention basin, including an oil spill detection and alarm system were completed in 1986. Quarterly water chemistry reports compiled from the data of Table 18, were submitted to the State of New Jersey in 1986 in accordance with NJDEP requirements. PPPL was within the allowable limits for all testing parameters during CY86.

Cooling water treatment was changed from a chromate-based corrosion inhibitor to a nonchromate inhibitor in June 1983. Water analyses downstream and ground water tests (see Tables 14-26) have not indicated concentrations of any environmental pollutants above applicable codes, regulations, or standards. As a result of the improvements made to the retention basin in 1986, the NJDEP is now requiring an application for discharge to ground water. This permit was applied for in 1986. An updated Spill Prevention Control and Countermeasures (SPCC) Plan was received in January 1985. All major action items of the plan have been addressed. These actions included modifications to the retention basin, an oil spill detection and alarm system at the C-site MG basement sump, an oil detection and alarm system at the retention basin, and spill containment dikes around three transformers. The SPCC response team meets quarterly for training sessions to improve their response efficiency in case a spill were to be detected. In addition, the Environmental Committee wrote a procedure, which was approved by Laboratory management, addressing responsibilities in case of a spill. . One requirement, the writing of a spill report, is handled by the Environmental Coordinator.

\subsubsection{Sanitary Sewage}

Sanitary sewage is discharged to the publicly owned treatment works operated by South Brunswick Township at Stony Brook. Flow rates are measured by the PPPL sanitary sewage metering station and average approximately 57,000 gallons per day (21 million gallons in 1986). Sampling of PPPL discharges, performed by the publicly owned treatment works, has determined that pretreatment is unnecessary. Therefore, PPPL 
is in compliance with the EPA Pretreatment Standard, 40 CFR Part 403 .

\subsubsection{Spills}

A Freon-113 spill onto the asphalt next to the CAS building required a cleanup which included removal of 13 cubic yards of asphalt, dirt, and debris. The cleanup prevented any impact to the local environment. A report was issued on the cause and close out of this effort (St86).

\subsubsection{Herbicides, Fertilizer, and Pesticides (Cl87)}

The use of herbicides, pesticides, and fertilizers is not controlled by PPPL but by Princeton University buildings and grounds maintenance personnel. These materials are applied in accordance with State and Federal regulations. Herbicides are applied by a certified applicator. Table 29 lists the quantities applied during CY86.

\subsubsection{Polychlorinated Biphenyls (PCBs)}

Beginning in CY82 PPPL started a program to uispose of PCB containing capacitors, transformers, and other contaminated items. During the early phases of the program all stored items in a GSA Warehouse in Belle Mead, NJ were discarded through approved disposal contractors. Remaining PCB items were labeled, as required by EPA regulations, and an inventory, inspection, and status report program was initiated. A Hazardous Material Coordinator was appointed to ensure that any newly identified leaking capacitors or transformers would be dispositioned promptly and properly. At the beginning of CY84 PPPL still had 15 PCB transformers and 6005 large capacitors containing PCBs. In CY84 375 large and 54 small PCB capacitors were disposed of as well as the oil and containers of two transformers (Ho85). In 1985, an additional 1330 large capacitors and 22 small capacitors were properly removed from the site. In 1986 a few small capacitors but no transformers 
were discarded. Other PCB capacitors are being disposed of as they are taken out of service. Transformer replacement has been initiated and is scheduled to meet the EPA requirements.

\subsubsection{Hazardous Wastes}

Responsibility for this program rests with the PPPL Hazardous Material Coordinator under the Materiel Control Office. $\therefore$ facility was set up in CY82 for temporary storage of hazardous materials. A new area was built in 1986. This facility has concrete floors with containment walls, fire and security alarms, fire extinguishers, an eye wash station, an emergency shower, and telephones.

The hazardous waste generator annual report (EPA ID number NJ1960011152) has been sutmitted for 1986 in accordance with EPA requirements (St87). During 1986, 35,431 pounds of materials were sent to a waste contractor. This included 10,653 pounds of PCBs (oil plus containers). Also 4025 gallons of liquid and 18 cubic yards of asphalt/soil from a Freon-113 spill were dispused of. Testing of soil from the vacated hazardous material storage area (Annex) indicated PCB levels which were less than 50 ppm (Mi87).

\subsection{Environmental Impact}

\subsubsection{Assessment of Radiation Dose to the Public}

PPPL is located in one of the less densely populated, but also one of the fastest growth areas in the metropolitan region between New York Ciry and Philadelphia. Previous census data indicate that approximately 16 million people live within $80 \mathrm{~km}$ (50 miles) of the site and approximately 225,000 within $16 \mathrm{~km}$ (10 miles) of PPPL. The detailed distribution of population as a function of distance is given in Tables 4-13A. Because of everincreasing commercial growth in this area, a demographic update had been planned for TFTR prior to tritium operations. A demographic study is presently underway for the CIT 
Environmental Assessment and will be available for next year's report.

The overall integrated exposure dose equivalent from all sources (excluding natural background) to a hypothetical individual residing at the PPPL site boundary $24 \mathrm{~h} / \mathrm{day}, 365 \mathrm{~d} / \mathrm{y}$ was estimated to be less than 1 mrem ( $0.01 \mathrm{mSv}$ ) for CY86 (Gi87). Detailed person-rem calculations for the surrounding population were not performed, because the value would be insignificant in comparison to the approximately 100 mrem ( $1 \mathrm{mSv}$ ) each individual receives from the natural background in New Jersey.

\subsubsection{Assessment of Nonradioactive Pollutants}

There were no activities during CY86 that created problems with respect to nonradioactive pollatants. The Freon-113 spill was detected and cleaned up with no significant environmental impact.

Polychlorinated biphenyls ( $P C B$ 's) and other toxic materials continue to be disposed of in accordance with EPA requirements. Herbicides, pesticides, and fertilizers were used in very limited quantities and are not expected to have any noticeable negative impact on the environment.

\subsection{QUALITY ASSURANCE FOR LABORATORY ANALYSIS}

Analysis of water samples for radioactivity was accomplished inhouse. In general, in-house procedures follow the HASL-300 Manual (Vo82). In-house procedures follow accepted techniques and are documented in the REML manual (REML86). PPPL participates in the EPA (Las Vegas) program as well as a program provided by the DOE Environmental Measurement Laboratory (EML) in New York City. These programs provide blind samples for analysis and subsequent comparison to values obtained by other participants, as well as to known values. Tritium results are shown in Table 28. 
In CY84 PPPL initiated a program to have its radiation counting laboratory certified by the State of New Jersey through the EPA QA program. In March 1986 the laboratory and its procedures were reviewed and inspected by EPA/Las Vegas and the NJDEP. The laboratory was certified for tritium analysis in urine and water. The goal in the coming year is to extend this certification to gamma spectroscopy and all other procedures and techniques.

The vendor used for nonradioactive water quality analysis participates in a State of New Jersey QA program and has a quality assurance plan (A185). Blind split samples were also submitted for analysis in 1986 (Table 27).

\subsection{FUTURE PROGRAM EXPANSION}

\subsection{Meteorological}

A meteorological tower was installed in November 1983. Data from this system will be used in updating dose calculations for the planned updated version of the TFTR FSAR. Data will also be evaluated by the CIT project in relation to siting the CIT at PPPL. Several dose assessment codes are being used by PPPL with respect to using the data from this tower. These codes include the required DOE standard AIRDOS-EPA, as well as PANVAN, XOQDOQ, and an Ontario Hydro version of TRITMOD. Future plans include considerations of hooking up a real-time output of the meteorological data.

\subsection{Water Quality}

The initial phases of a ground water monitoring program began in CY85. Analysis of water samples from two D-site wells was added to the monitoring program in CY86. CIT evaluations will determine whether or not this program has to be expanded. 


\subsection{Radioactive Effluents}

\subsubsection{Air Gaseous and Particulate}

Based on collected data, a decision was made in CY84 to limit the specific air and particulate real-time monitors at the EZB to a beta detector only. One system was calibrated in CY86 and is presently being installed. Three other systems will be procured for on-site stations. Environmental tritium monitors tested in CY86 will be deployed in CY87.

\subsubsection{Off-Site Radiological Monitoring}

An off-site grab sample water analysis program is well established. Whether or not more sampling points will be added in the future depends on reevaluation of the program, which is done annually. Locations for off-site tritium and particulate monitoring stations were negotiated in CY86. Placement of hardware at these sites is expected to be finished in CY87. Soil and vegetation sampling is underway and will continue.

\subsection{Nonradioactive Effluents}

Air effluent standards will continue to be met by following the guidelines of the NJDEP. Any potential toxic materials will be monitored and disposed of in accordance with applicable regulations and accepted guidelines. With respect to the retention basin, application has been made for a ground water discharge permit. Also, because of the addition of an oil separator on the retention basin, the NJDEP had requested that we apply for a treatment works permit. A permit application was made and a subsequent waiver was granted (Ku86). 


\subsection{REGULATIONS AND SAFETY CRITERIA}

The appropriate Radiation Protection Standard for penetrating radiation was taken from DOE Order 5480.1A, Chapter XI. Specific criteria for implementing these standards on TFTR are contained in TFTR Operational Safety Requirements, in particular OSR/TFTR/0-2F-C. The Concentration Guides used in the analyses of surface water samples for radioactivity were taken from DOE Order 5480.1A, Chapter XI, Table II, Column 2 (Water in Uncontrolled Areas). The concentration guides for airborne activity are taken from the same DOE Order, Table I, Column 1 (Concentration in Air in Uncontrolled Areas). Tritium, for example, is listed as $2 \times 10^{-7} \mathrm{uCi} / \mathrm{ml}$. The Laboratory was also in compliance with the new DOE draft Order 5480.11, of which some interim requirements on dose to the public were established by a DOE letter (Mi85).

Air and Water Pollutions Standards for nonradioactive pollutants were taken from the New Jersey Administrative Code (NJAC), Department of Environmental Protection 7:9-4, et seq. The appropriate regulations for hazardous waste are found in the U.S. Code of Federal Regulations, 40 CFR 761 and 40 CFR 260265, respectively.

\subsection{ACKNOWLEDGEMENTS}

E. Mitman, III and J. Gilbert compiled the data for radiation analysis, $O$. Griesbach performed in-house radiation analyses, and $\mathbf{J}$. Fennimore and $\mathrm{K}$. Chase worked on instrument installation and calibration. These individuals are staff members of the PPPL Project and Operational Safety Office, Health Physics Branch. R. Mitchell and J. Tobin, MD, of the Occupational Medicine and Safety Office reviewed nonradioactive pollutant analysis data. C. Kircher is responsible for all water utilization information and forwarding of relevant data to DOE for environmental protection permits. S. Holcombe and S. Larson are responsible for toxic waste disposal. Various other PPPL individuals reviewed the manuscript. 
This work is supported by the U.S. Department of En rgy Contract No. DE-AC02-76CHO3073.

\subsection{REFERENCES}

A185 Alinea, E.A., 1985, Princeton Testing Laboratory Quality Control Manual, Princeton Testing Laboratory, Princeton, NJ.

Cl86 Clark, G. J., 2/2/87, "Chemical Use," Princeton University Internal memo.

Co81 Corley, J.P., et al., 1982, A Guide for: Environmental Radiological Surveillance at U.S. Department of Energy Installations DOE/EP-023, (National Technical Information Service).

DOE81 DOE Order 5480.1, Ch. XI, 8/13/81, Environmental Protection. Safety and Health Protection Program for DOE Operations. U.S. Department of Energy, Operational and Environmental Safety Division.

El84 Ellis, R., Jr., and Stencel, J.R., February 1984, Safety Assessment for the $S-1$ Spheromak. Princeton Plasma Physics Laboratory Report No.2083.

Fl84 Fleming, R.B., et al., February 1984, Safety Assessment Docnment for the Princeton Beta Experiment. Princeton Plasma Physics Laboratory (unpublished).

FSAR82 Final Safety Analysis Report, Tokamak Fusion Test Reactor Facilities, Princeton Plasmas Physics Laboratory, 1982.

Gi87 Gilbert, J., May 1987, "PPPL Yonizing Radiation Report for Calendar Year 1986," JG-47, Princeton Plasma Physics Laboratory Internal Report. 
Gr85 Griesbach, O., and Stencel, J.R., January 1985, "An Environmental Monitoring Program for a Fusion Test Reactor," Proceedings of the 18th Midvear Topical Symposium of the Health Physics Society. Colorado Springs, CO, 227-233.

Jo74 Jordan, C.F., Stewart, M., and Kline, J., 1974, "Tritium Movement in Soils: The Importance of Exchange and High Initial Dispersion," Health Physics. 27, 37-43.

Ki87 Kircher, C., 2/11/87, "Annual Environmental Report for CY86," Princeton Plasma Physics Laboratory, Internal Memo.

Ko86a Kolibal, J., et al., 1986, Meteorological Data Summaries for the TFTR from January 1984 to December 1985, Princeton Plasma Physics Report No. 2369.

Ko86b Kolibal, J., 3/24/86, "Sectorized Agricultural and Population Data Estimates," EAD-1442, Plasma Physics Laboratory Internal Memo.

Ku86 Kurisko, P.C., 12/5/86, "Treatment Works Approval Waiver NJPDES No. NJ0023922," NJDEP letter to H. Mix, DOE/PAO.

Mc83 McCarthy, E.F., and Errera, L.J., 8/15/83, Final Monitoring Plan: Tokamak Fusion Test Reactor Meteorological Monitoring Program, TRC Consultants, Inc., 800 Connecticut Blvd., East Hartford, CT 06108.

Mi85 Mix, H. C., Nov. 85, "Radiation Standard for Protection of the Public in the Vicinity of the Department of Energy (LoE) Facilities," DOE/PAO letter to PPPL.

Mi87 Mitchell, R., 1/19/87, "Annual Environmental Report," Plasma Physics Laboratory Internal Memo.

Mu77 Murphy, C.E., Jr., Watts, J.R., and Corey, J.C., 1977, "Environmental Tritium Transport from Atmospheric Release of Molecular Tritium," Health Physics, 33, 325-331.

Mu82 Murphy, C.E., Jr., Sweet, C.W., and Fallon, R.D., 1982, "Tritium Transport Around Nuclear Facilities," Nuclear Safety. 23, 667-685.

Na84 Nagy, A., and Beane, F., August 1984, Safety Assessment for the RF Test Facility, Princeton Plasma Physics Laboratory Report No. 2129. 
Nu79 NUREG/CR-2227, "Radioactive Materials Released from Nuclear Power Plants-1979."

PSAR78 Preliminary Safety Analysis Repart, Princeton Plasma Physics Laboratory Tokamak Fusion Test Reactor, 1978.

REML86 Radiological Environmental Monitoring Laboratory Manual. Princeton Plasma Physics Laboratory, 1986.

St81 Steiner, P.A., 1981, An Aerial Radiological Survey of the Princeton Plasma Physics Laboratory and Surrounding Area, U.S. DOE Remote Sensing Laboratory Report, EGG-1182-1806, UC-41.

St82 Strenge, D.L., Kennedy, W.E., Jr, and Corley, J.P., 1982 , Environmental Dose Assessment Methods for Normal Operations of DOE Nuclear Sites. PNL-4410/UC-11.

St85 Strohl, M.E., 9/16/85, "Population Distribution," Princeton Plasma Physics Laboratory Internal Report, MS-928.

St86 Stencel, J.R., 1986, "Environmental Protection Spill Cleanip Report EP86-01, CAS Building Freon Spill," JRS-736, Princeton Plasma Physics Laboratory Internal Report.

St87 Stencel, J.R., "Annual Hazardous Waste Generator Report for CY1986," Princeton Plasma Physics Report to DOE/PAO, JRS-798.

Vo82 Volchok, H.L., and de Planque, G., 1982, EML Procedures Manual HASL-300, Department of Energy, Environmental Measurements Laboratory, 376 Hudson St., NY, NY 10014. 


\section{TFTR RADIATIOH EXPOSURE CRITERIA}

The research facility radiation exposure criteria itemized in this table ghall be invoked for the trin only and ghall not be construed as belng applicable to subsequent fusion test facilities, research factitties, or reactor projects. The values quoted are for whole body exposures, however, the DoE manual requirements for other organs (hands, arms, bones, etc.) and other time periods (quarterly) are aiso applicable to trir and reductions between limits and destgn objectives ghall be consistent with those of the table.

\begin{tabular}{|c|c|c|c|c|}
\hline \multirow[b]{2}{*}{ Cond $1 t 10 n$} & \multicolumn{2}{|c|}{$\begin{array}{l}\text { off-\$1te } \\
\geq 125 \mathrm{II}\end{array}$} & \multicolumn{2}{|c|}{$\begin{array}{l}\text { On-s te } \\
<125 \mathrm{~m}\end{array}$} \\
\hline & IImit & $\begin{array}{c}\text { Design } \\
\text { object } 1 \text { ve }\end{array}$ & $t 1 m i t$ & $\begin{array}{c}\text { Design } \\
\text { objective }\end{array}$ \\
\hline $\begin{array}{l}\text { Routine } \\
\text { operation } \\
\text { mIem/yr } \\
\text { [footnotes } \\
\text { (a).(b) a }\end{array}$ & $\begin{array}{c}500 \\
\text { to an } \\
1 \text { ndividua } 1 \\
\text { (e) }\end{array}$ & $\begin{array}{c}\text { coo } \\
\text { to an } \\
\text { tndividual } \\
\text { (b) }\end{array}$ & $\begin{array}{c}500 \\
\text { in an } \\
\text { uncontrolled } \\
\text { area }\end{array}$ & $\begin{array}{l}\frac{1}{100} \\
\text { un an } \\
\text { ancontrolled } \\
\text { area }\end{array}$ \\
\hline & $\begin{array}{c}170 \\
\text { average } \\
\text { population } \\
\text { membet } \\
\text { (e) }\end{array}$ & $\begin{array}{l}\leq \leq 35 \\
\text { average } \\
\text { population } \\
\text { member }\end{array}$ & $\begin{array}{c}5000 \\
\text { In a } \\
\text { controlled } \\
\text { area }\end{array}$ & $\begin{array}{c}\leq 1000 \\
\text { in a } \\
\text { controlled } \\
\text { area }\end{array}$ \\
\hline $\begin{array}{l}\text { Accident } \\
\text { rem } \\
{[\text { footnotes }} \\
\text { (c) and (d)] }\end{array}$ & 25 & $\frac{<5}{(d)}$ & 25 & 25 \\
\hline
\end{tabular}

(a) Routine operation consists of:

1) Normal component operation including shutdown, repair, malntenance, checkout, adjustment, etc.

2) Operational occurrences such a leaks, loss of power, and component malfunctions that are likely to occur once or more during the Ilfe of the facility.

(b) For normal operation, defined in (a) 1) above, the off-site design objective shall be 10 mrem/yr.

(c) Accident conditions consist of:

1) Very low probability events such as most intense predicted" natural phenomena.

21 Low probabilify events such as "most probable" natural phenomena and other component failure events that are not likely to occur during the life of the facility.

(d) For those accident conditions defined by (c) 1) above, the off-site design objective shall be 5 rem and that for (c) (2) above, 1 rem.

(e) For emisgion of atrtorne radionuclides, the off-site limit on doge equivalent is 25 mrem/yr to the whole body and 75 mrem/yr to the citical organ. 


\section{TABLE 2 *}

\section{CRITICAL PATHWAYS}

Path I.D.

A 1

12

A 3

L 1

L 2

L 3

L 4

\section{Discharge Pathway}

Atmospheric - - Whole Body Exposure

Atmospheric -- Inhalation Exposure

Atmospheric $\rightarrow$ Deposttion on Sol1 \&

vegetation, Ingestion, Whole Body Exposure

Liquid

Water Way $\rightarrow$ Drinking Water Supply -.-D Man

Liquid Water Way $\rightarrow$ External Exposure

Liquid Water Way $\rightarrow$ Sediments $-\rightarrow$

External Exposure

Eiquid Water Way $\rightarrow$ Fish $\rightarrow$ Man

* TAKEn FRUM tFTR FSAR table 8.5-1 
TABLE 3 *

MONITORING PROGRAM COVERING CRITICAL PATHWAYS

CRITICAL SAHRLE POINT TYPE OF SAMPLE PATH I.D. DESCRIPTION

Surface

L $1, I 2, L 4$

L 3

Surface Water I $1, L_{2}$

Air

$A \uparrow-\mathbf{A} 3$

Direct

Radiation
A 1 - A 3

$$
\text { A } 1-\mathbf{A} 3
$$

Air
Test $\operatorname{Cel} 1$

vault

HVAC Discharge

1) Cooling Hater Discharge Drainage

2) Bee Brook Upstrean 4 Downstream

3) D\&R Canal

Delaware Raritan Canal Waste collection
Tanks

4 Locations at Site Perlmeter
Continuous

Required

BY

Filing

Continurus

Continugus

Continuous

SAMPLING

Monthly of Weekiy samples

Blenntaly

Gross $Y$

GIOSS B

Gross $Y$

Gross $B$

Rata

Gross $Y$ Gios $B$ H (Gas

Water

vapox

${ }^{3} \mathrm{H}$ (Gas :

Hater

vapor)

Gross $Y$ Gross $B$

3, part = iculates

Continuous

$\gamma, n$, HTO/ ${ }^{3} d$, particulates 
TABLE 4*

1974 POPULATION ESTIMATES WITHIN ANNULAR SECTORS, 0-10 MILES

TOTAL

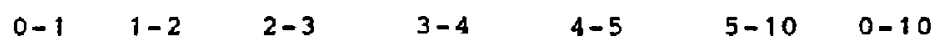

Sector Mile Miles Miles Miles Miles Miles Miles sector

$\begin{array}{rrrrrrrrr}\text { N } & 7 & 430 & 289 & 182 & 164 & 7,869 & 8,941 & \text { N } \\ \text { NNE } & 0 & 22 & 144 & 137 & 3,284 & 10,353 & 13,940 & \text { NNE } \\ \text { NE } & 7 & 58 & 202 & 690 & 274 & 14,029 & 15,260 & \text { NE } \\ \text { ENE } & 11 & 6 & 0 & 123 & 271 & 9,561 & 9,972 & \text { ENE } \\ \text { E } & 0 & 0 & 55 & 25 & 43 & 11,796 & 11,5,9 & \text { E } \\ \text { ESE } & 6 & 32 & 63 & 68 & 123 & 3,705 & 3,997 & \text { ESE } \\ \text { SE } & 3 & 23 & 356 & 29 & 94 & 13,511 & 14,016 & \text { SE } \\ \text { SSE } & 6 & 2,859 & 49 & 27 & 71 & 13,837 & 15,849 & \text { SSE } \\ \text { S } & 0 & 293 & 400 & 570 & 198 & 2,839 & 4,300 & \text { S } \\ \text { SSW } & 0 & 95 & 689 & 1,221 & 530 & 26,112 & 28,646 & \text { SSW } \\ \text { SW } & 0 & 6 & 679 & 43 & 899 & 20,690 & 22,317 & \text { SW } \\ \text { WSW } & 0 & 394 & 71 & 873 & 253 & 9,850 & 11,441 & \text { WSW } \\ \text { W } & 3 & 835 & 5,712 & 5,832 & 695 & 7,586 & 20,663 & \text { W } \\ \text { WNW } & 0 & 437 & 2,889 & 1,455 & 294 & 6,788 & 11,863 & \text { WNW } \\ \text { NW } & 3 & 198 & 786 & 688 & 221 & 3,183 & 5,079 & \text { NW } \\ \text { NNW } & 3 & 415 & 259 & 144 & 698 & 2,854 & 4,373 & \text { NNW } \\ \text { TOTAL } & 49 & 6,103 & 12,642 & 12,107 & 8,112 & 103,563 & 202,576 & \text { TOTAL }\end{array}$

*TAKEN FROM TFTR FSAR, TABLE $2.1 .2-1$ 
TABLE 5*

1985 POPULATION PROJECTIONS WITEIN ANNULAR_SECTORS, $0-10$ MILES

\begin{tabular}{|c|c|c|c|c|c|c|c|c|}
\hline & & & & & & TOT & & \\
\hline & $0-1$ & $1-2$ & $2-3$ & $3-4$ & 4-5 & $5-\overline{10}$ & $0-10$ & \\
\hline Sector & Mile & Miles & Miles & Miles & Miles & Miles & Miles & Sector \\
\hline$N$ & 9 & 529 & 355 & 229 & 205 & 9,850 & 11,177 & $\mathrm{~N}$ \\
\hline NNE & 0 & 27 & 177 & 169 & 4,041 & 13,008 & 17,422 & NNE \\
\hline$N E$ & 9 & 71 & 248 & 849 & 337 & 7,769 & 9,283 & $\mathrm{NE}$ \\
\hline ENE & 16 & 8 & 0 & 151 & 333 & 12,406 & 12,914 & ENE \\
\hline E & $1: 217$ & 0 & 74 & 31 & 5.3 & 13,956 & 15,331 & E \\
\hline$E S E$ & 9 & 46 & 1,600 & 78 & 144 & 4,157 & 6,034 & $E S E$ \\
\hline$S E$ & 4 & 33 & 4,356 & 33 & 108 & 16,373 & 20,907 & $\mathbf{S E}$ \\
\hline SSE & 9 & 4,117 & 71 & 35 & 82 & 16,018 & 20,332 & SSE \\
\hline$s$ & 0 & 548 & 456 & 650 & 226 & 3,788 & 5,668 & $\mathbf{s}$ \\
\hline SSW & 0 & 137 & 784 & 1,392 & 604 & 30,893 & 33,810 & ssw \\
\hline SW & 0 & 9 & 774 & 49 & 1,025 & 24.987 & 26,844 & Sผ \\
\hline พลS & 0 & 552 & 81 & 1,126 & 326 & 12,765 & 14,850 & WSW \\
\hline$n$ & 683 & 3.793 & 6,683 & 6,823 & 897 & 10,252 & 29,131 & พ \\
\hline พNW & 0 & 564 & 3,611 & 1,877 & 379 & 8,815 & 15,246 & WNW \\
\hline N $\boldsymbol{H}$ & 4 & 255 & $1,0 \dagger 4$ & 860 & 263 & 3,815 & 6,211 & $\mathrm{NW}$ \\
\hline NNW & 4 & 511 & 326 & 186 & 893 & 3,433 & 5,353 & NNW \\
\hline TOTAL & 1,964 & 11,200 & 0,610 & 14,538 & 9,916 & 192,285 & 250,513 & TOTAL \\
\hline
\end{tabular}

tTAKEN FRom tFtr fSar takLE 2.1.2-3 


\section{TABLE 6*}

1970 RESIDENT POPULATION WITHIN ANNULAR SECTORS BETWEEH $10-50$ MILES

\begin{tabular}{|c|c|c|c|c|c|c|}
\hline Sector & $\begin{array}{r}10-20 \\
\text { Miles } \\
\end{array}$ & $\begin{array}{l}20-30 \\
\text { Miles }\end{array}$ & $\begin{array}{l}30-40 \\
\text { MIIess }\end{array}$ & $\begin{array}{l}40-50 \\
\text { M11es }\end{array}$ & Eota1 & Sector \\
\hline $\mathbf{N}$ & 69,330 & 35,961 & 143,546 & 60,073 & 308,910 & $\mathbf{N}$ \\
\hline NNE & 133,838 & 237,191 & 354,551 & 544,621 & $1,270,201$ & NNE \\
\hline NE & 185,569 & 437.917 & $1,483,657$ & $3,893,770$ & $6,000,9 \pm 3$ & NL \\
\hline ENE & 119,874 & 166,477 & $1,134,648$ & $1,629,062$ & $3,050,061$ & ENE \\
\hline E & 33,077 & 112,389 & 69,706 & 0 & 215,172 & $E$ \\
\hline ESE & 29,247 & 35,408 & 111,280 & 0 & 175,935 & ESE \\
\hline SE & 6,928 & 52,737 & 108,930 & $\ddot{2}, 033$ & 170,628 & $\mathbf{S E}$ \\
\hline SSE & 5,004 & 4,984 & 7,887 & 11,023 & 28,898 & sse \\
\hline $\mathbf{s}$ & 5,933 & 61,238 & 7,349 & 3,935 & 78,455 & $s$ \\
\hline SSW & 52,983 & 55,122 & 56,229 & 114,782 & 279,116 & SSW \\
\hline SW & 247,409 & 324,276 & $1,368,041$ & $1,220,152$ & $3,159,878$ & sw \\
\hline WSW & 35,985 & 117,952 & 310,930 & 289,105 & 753,972 & WSW \\
\hline $\mathrm{W}$ & 12,576 & 20,100 & 69,806 & 56,145 & $158,70.7$ & $\mathrm{w}$ \\
\hline WNW & 6,054 & 10,112 & 15,399 & 254,563 & 286,128 & WNW \\
\hline NT & 12,819 & 12,698 & 66.455 & 85,836 & 177,808 & N W \\
\hline NNW & 14,429 & 14,462 & 34,875 & 14,937 & 78,703 & NNW \\
\hline TOTAL & 971,055 & 99,104 & 5,343 &, 037 & $, 193,485$ & \\
\hline
\end{tabular}

tTaker from tFtr FSAR, Table $2.1 .2-4$ 
TABLE 7. POPULATION OF SMSA'S MITHIN 50 MILES OF THE TFTR SITE $(S t 85)$

\begin{tabular}{|c|c|c|c|}
\hline SMSA'S* & $\begin{array}{l}\text { FSAR (1983) } \\
\text { Census of } \\
\text { Aprt1 1970 }\end{array}$ & $\begin{array}{c}\text { Estimate } \\
\text { For July } \quad 1974 \\
\end{array}$ & $\begin{array}{l}\text { Census }{ }^{1} \text { of } \\
\text { April } 1900\end{array}$ \\
\hline $\begin{array}{l}\text { Allentown-Bethlehem } \\
\text { Easton, PA } \\
\text { (N.J. portion) }\end{array}$ & 73,960 & 79,200 & 84,829 \\
\hline Jersey City, NJ & 607,839 & 584,900 & 556,972 \\
\hline $\begin{array}{l}\text { Long Branch } \\
\text { Asbury Park, NJ }\end{array}$ & 461,849 & 486,100 & 503,173 \\
\hline $\begin{array}{l}\text { New Brunswick } \\
\text { Perth Amboy } \\
\text { Sayreville, NJ }\end{array}$ & 583,813 & 549,900 & $595=893$ \\
\hline $\begin{array}{l}\text { New York, NY } \\
\text { (NJ portion) }\end{array}$ & $9,973,716$ & $9,634,400$ & $9,120,346$ \\
\hline Newark, NJ & $2,057,468$ & $2,014,500$ & $1,965,969$ \\
\hline $\begin{array}{l}\text { Paterson-Clifton- } \\
\text { Passaic, NJ }\end{array}$ & 460,782 & 456,700 & 447,585 \\
\hline $\begin{array}{l}\text { Philadelphia, PA } \\
\text { (NJ portion) }\end{array}$ & 952,104 & $1,000,400$ & $1,034,109$ \\
\hline Trenton, NJ & 304,116 & 319,800 & 307,863 \\
\hline TOTAL & $15,475,647$ & $15,125,900$ & $14,616,739$ \\
\hline
\end{tabular}

* Standafd Metropolitan statistical Area

1 Source: 1980 Census of Population aná Housing odeA 
Table 8. Census and Population Projections for Counties in New Jersey Within 10-50 Miles of TFTR Site (st85)

\begin{tabular}{|c|c|c|c|c|c|c|c|}
\hline \multirow[b]{2}{*}{ County } & \multicolumn{2}{|c|}{ FSAR (1983) } & \multirow{2}{*}{$\begin{array}{l}\text { Census }{ }^{1} \text { of } \\
\text { April } 1980\end{array}$} & \multirow{2}{*}{\multicolumn{4}{|c|}{ Projections for July $1^{1}$}} \\
\hline & $\begin{array}{r}\text { Census of } \\
\text { April } 1970 \\
\end{array}$ & $\begin{array}{l}\text { Projection } \\
\text { for } 1985\end{array}$ & & & & & \\
\hline Atlantic & 175,770 & 202,760 & 194,119 & 206,700 & 220,000 & 233,400 & 245,800 \\
\hline Bergen & 897,148 & $1, n 89,140$ & 845,385 & 802,600 & 767,100 & 736,200 & 707,800 \\
\hline Burlington & 323,132 & 413,600 & 362,542 & 391,200 & 422,300 & 454,800 & 487,000 \\
\hline Camden & 456,291 & 553,030 & 471,650 & 482,900 & 497,400 & 512,700 & 526,400 \\
\hline Essex & 932,320 & 985,530 & 851,304 & 813,700 & 785,400 & 751,600 & 739,900 \\
\hline Gloucester & 172,681 & 217,980 & 199,917 & 216,400 & 233,600 & 250,600 & 265,700 \\
\hline Hudson & 607,839 & 618,400 & 556,972 & 538,200 & 524,400 & 513,800 & 506,000 \\
\hline Hunterdon & 69,718 & 94,220 & 87,361 & 94,600 & 301,300 & 107,700 & 113,200 \\
\hline Morris & 383,454 & 449,110 & 407,630 & 412,800 & 418,200 & 422,700 & 423,900 \\
\hline Ocean & 208,470 & 289,860 & 346,038 & 407,800 & 470,200 & 536,700 & 605,700 \\
\hline Passaic & 460,782 & 545,980 & 447,585 & 440,500 & 434,800 & 428,700 & 421,200 \\
\hline Sussex & 77,528 & 100,270 & 116,119 & 136,200 & 156,700 & 177,800 & 198,200 \\
\hline Union & 543,116 & 642,210 & 504,094 & 482,400 & 467,800 & 458,800 & 454,200 \\
\hline Warren & 73,960 & 83,590 & 84,429 & 90,300 & 96,300 & 102,200 & 107,400 \\
\hline Subtatal & $5,382,215$ & $6,285,680$ & $5,475,145$ & $5,516,300$ & $5,595,500$ & $5,697,700$ & $5,802,400$ \\
\hline
\end{tabular}

1. New Jersey Factbook, November 1984

State Data Center, New Jersey Department of Labor

Div. of Planning \& Research, Office of Demographics \& Analysis

CN, Trenton, New Jersey 08525-0388

Reference from: Princeton University Computer Center

(which is part of the network for the State Data Center) 
TABLE 9. POPULATION OF COUNTIES IN NEW YORK AND PENNSYLVANIA WITHIN 10-50 MILES OF TEE TFTR SITE. (StB5)

\section{County}

Kings

New York

Quesns

R I chmond

SUBTOTAL
-Censlas of

Aprif 1970

$2,602,000$

$1,539,000$

$1,987,000$

295,000

$6,423,000$
NEW YORX ${ }^{1}$

$\begin{array}{r}\begin{array}{c}\text { Projection } \\ \text { for } 1985\end{array} \\ \hline 2,287,000 \\ 1,309,000 \\ 1,909,000 \\ 396,000 \\ \hline\end{array}$

Census of

April 1980

$2,231,028$

$1,428,265$

$1,881,325$

352,029

$5,901,000$

$5,892,667$

Projection

for 1990

$2,225,192$

$1,452,080$

$1,914,038$

394,783

$5,986,093$

\section{County}

Bucks

Chester

Delaware

Lehigh

Manroe

Mon tgomery

Northhampton

Philadelphia

SUBTOTAL

TOTAL
*Census of

April 1970

457,981

278,362

602,741

255,679

45,470

$6=4,304$

214,807

$1,927,673$

$4,367,617$

$10,790,617$
* Projection

fox 1985

511,609

366,823

645,373

293,715

55,483

759,207

229,767

$1,952,912$

$4,814,889$

$10,715,889$
Census of April 1980

479,211

316,660

555,007

272.349

69,409

643,621

225,418

$1,689,210$

$4,249,885$

$10,142,552$
Projection

Eor 1990

514,387

379,431

506,311

271,602

87,146

656,551

223,826

$1,595,393$

$4,234,647$

$10,220,740$

1. New York Department of Commeree April 1985

2. Pennsylunia state Data Center Apr11 1984 
Table 10. Population Projections for Counties in New Jersey: 1985-2000 Within 0-10 Miles of TFTR Site. (St85)

\begin{tabular}{|c|c|c|c|c|c|c|}
\hline \multirow[b]{2}{*}{ County } & \multicolumn{2}{|c|}{ Census Counts ${ }^{1}$} & \multicolumn{4}{|c|}{ Projections for July $1^{1}$} \\
\hline & April 1970 & April 1980 & 1985 & 1990 & 1995 & 2000 \\
\hline Mercer & 304,116 & 307,863 & 307,100 & 306,300 & 304,700 & 301,900 \\
\hline Middlesex & 583,813 & 595,893 & 598,400 & 601,200 & 603,000 & 603,300 \\
\hline Somerset & 198,372 & 203,129 & 202,000 & 201,700 & 201,400 & 199,600 \\
\hline Monmouth & 461,849 & 503,173 & 525,100 & 546,400 & 566,000 & 580,800 \\
\hline Subtotal & $1,548,150$ & $1,610,058$ & $1,632,600$ & $1,655,600$ & $1,675,100$ & $1,685,600$ \\
\hline
\end{tabular}

1. New Jersey Factboak, November 1984 State Data Center

New Jersey Department of Labor

Division of Planning \& Research

Office of Demographics and Analysis

CN, Trenton, New Jersey 08625-0388

Note: These counties were not listed in FSAR 
Table 11. Population of Municipalities Within 0-10 Miles of TFTR Site. (St85) (Mercer County)

\begin{tabular}{|c|c|c|c|c|c|}
\hline \multirow[b]{3}{*}{ Municipality. } & \multicolumn{2}{|c|}{ FSAR (1973) } & \multirow{3}{*}{$\begin{array}{c}\text { Census } 1 \\
\text { of } \\
1980\end{array}$} & \multirow{2}{*}{\multicolumn{2}{|c|}{ Projections $^{1}$}} \\
\hline & \multirow{2}{*}{$\begin{array}{c}\text { Census } \\
\text { of } \\
1970 \\
\end{array}$} & \multirow{2}{*}{$\begin{array}{l}\text { Projec- } \\
\text { tion } \\
\text { for } 1985\end{array}$} & & & \\
\hline & & & & 1990 & 2000 \\
\hline MERCER COUNTY (TOTAL) & 304,116 & 365,220 & 338,863 & 340,000 & 359,400 \\
\hline East Windsor Twp. & 11,736 & 24,607 & 21,041 & 23,500 & 26,000 \\
\hline Hightstown (Boro) & 5,431 & 6,624 & 4,581 & 5,000 & 5,100 \\
\hline Hamilton Twp. & 79,609 & 97,024 & 81,801 & 87,700 & 90,000 \\
\hline Hopewel1 Twp. & 10,030 & 16,008 & 10,893 & 11,025 & 13,650 \\
\hline Hopewe]l (Boro) & 2,271 & 2,666 & 2,001 & 2,050 & 2,100 \\
\hline Pennington (Boro) & 2,151 & 2,993 & 2,109 & 2,300 & 2,300 \\
\hline Lawrence Twp. & 19,567 & 25,011 & 19,724 & 28,200 & 33,900 \\
\hline Princeton Twp. & 13,651 & 18,009 & 13,683 & 14,400 & 14,700 \\
\hline Princeton (Boro) & 12,311 & 14,000 & 12,035 & 12,600 & 12,700 \\
\hline Washington Twp. & 3,311 & 5,003 & 3,487 & 8,500 & 8,800 \\
\hline West Windsor Twp. & 6,431 & 8,573 & 8,542 & 15,600 & 17,500 \\
\hline Subtotal & 166,499 & $220,51 B$ & 179,897 & 210,975 & 226,750 \\
\hline
\end{tabular}

1. "Mercer County Growth Management Plan," Mercer County Planning Board, 1985. 
Table 12. Population of Municipalities Within 0-10 Miles of TFTR Site (St85)

(Middlesex County)

\begin{tabular}{|c|c|c|c|c|c|}
\hline \multirow[b]{2}{*}{ Municipality } & \multicolumn{2}{|c|}{ FSAR (1983) } & \multirow[b]{2}{*}{$\begin{array}{c}\text { *Census } \\
\text { of } \\
1980 \\
\end{array}$} & \multirow{2}{*}{\multicolumn{2}{|c|}{$\frac{\text { Projections }}{1990}$}} \\
\hline & $\begin{array}{c}\text { Census } \\
\text { of } \\
1970 \\
\end{array}$ & $\begin{array}{c}\text { Projec- } \\
\text { tion } \\
\text { fo: } 1985 \\
\end{array}$ & & & \\
\hline MIODLESEX COUNTY (TOTAL) & 583,813 & 730,160 & 595,893 & $\star 690,400$ & $\star 757,100$ \\
\hline Cranbury (Twp.) & 2,253 & 2,629 & 1,927 & $\star \star 3,417$ & $* \pi 4,6,32$ \\
\hline East Brunswick (Twp.) & 34,166 & 48,119 & 37,711 & $\star \star 52,960$ & $\star \star 59,324$ \\
\hline Helmetta (Boro) & 955 & 1,222 & 955 & $\star \star 1,002$ & $\star \star 1,031$ \\
\hline Monroe (iwp.) & $9, .138$ & $11,4 \mathrm{fA}$ & 15,858 & $\star \star 1 \overline{0}, 413$ & $\star \star 18,015$ \\
\hline Jamesburg (Boro) & 4,584 & 5,476 & 4,114 & $\star \star 5,298$ & $\star \star 5,170$ \\
\hline North Brunswick (Twp.) & 16,691 & 22,040 & 41,442 & $\star * 30,847$ & $\star \star 30,617$ \\
\hline Plainsboro (Twp.) & 1,648 & 15,075 & 5,605 & $\star \star 14,046$ & $* * 17,026$ \\
\hline South Brunswick (Twp.) & 14,058 & 18,546 & 17,127 & $\star \star 31,001$ & $\star \star 43,704$ \\
\hline SuhtotaT & 83,493 & 124,571 & 124,739 & 154,984 & $179,3: 9$ \\
\hline
\end{tabular}

*New Jersey Revised Total Age and Sex Population Projections, 1983

New Jersey Department of Labor

Office of Demographics and Economic Analysi.5

Divisior: of Planning and Research

CN 388

Irenton, NJ 08625-0288

(Total Projections for Middlesex Cornty Only)

* Municipal Forecasts by Middlesex County

Planning Board, August 1979 
Table 13. Population of Municipalities Within 0-10 Miles of TFTR Site. (5t85) (Somerset County)

\begin{tabular}{|c|c|c|c|c|c|}
\hline \multirow[b]{3}{*}{ Municipality } & \multicolumn{2}{|c|}{ FSAR (1983) } & \multirow{3}{*}{$\begin{array}{c}\text { Census } \\
\text { of } \\
1980 \\
\end{array}$} & \multirow{2}{*}{\multicolumn{2}{|c|}{ Projections }} \\
\hline & \multirow{2}{*}{$\begin{array}{c}\text { Census } \\
\text { of } \\
1970 \\
\end{array}$} & \multirow{2}{*}{$\begin{array}{l}\text { Projec- } \\
\text { tion } \\
\text { for } 1985 \\
\end{array}$} & & & \\
\hline & & & & 1990 & 2000 \\
\hline SOMERSET COUNTY (TOTAL) & 198,372 & 252,130 & 203,129 & $\star 246,800$ & $\star 284,000$ \\
\hline Franklin (Twp.) & 30,389 & 40,270 & 31,358 & $* * 45,724$ & $* * 52,651$ \\
\hline Hill sbo rough (Twp.) & 11,051 & 15,225 & 19,061 & $* * 26,665$ & $\star * 30,725$ \\
\hline Montgomery (Twp.) & 6,353 & 7,640 & 7,360 & $* * 11,099$ & $\star \star 15,299$ \\
\hline Rocky Hill (Boro) & 917 & 1,184 & 717 & $* * 717$ & $* \star 1,017$ \\
\hline Subtatal & 48,720 & 64,319 & 58,496 & 84,205 & 99,692 \\
\hline
\end{tabular}

*New Jersey Revised Total Age and Sex Population Projections, 1983

N.J. Department of Labor, Office of Demographics and Economic Analysis, Division of Planning and Research

CN 388, Trenton, NJ 08625-0388

(Total projections for Somerset County onty)

**Municipal Projections by Somerset County Planning Board, 1984 
TABLE 13A (Ku86)

SECTORIZED POPULATION DATA TO LMILE

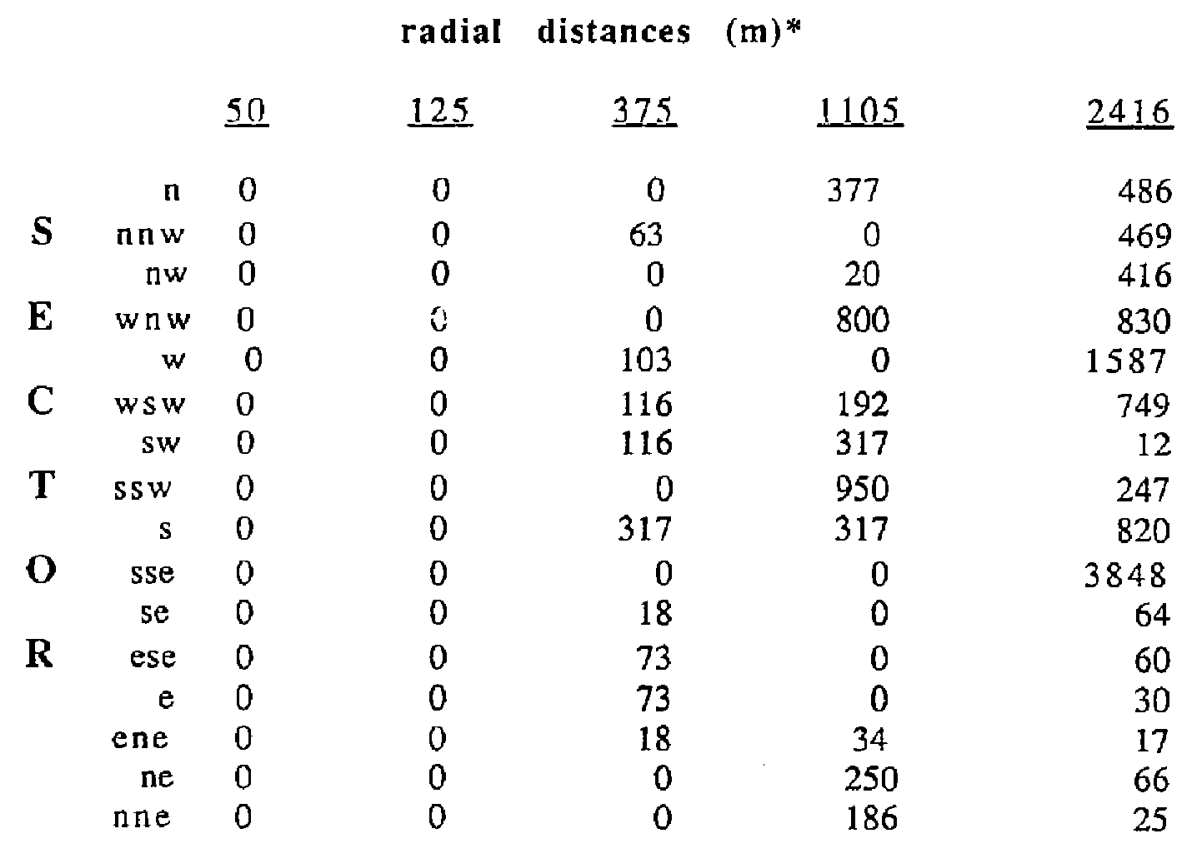

* The radii shown are midpoints of the sector radial boundaries. 
T'ABLE 14

WATER QUALITY MONITORING DATA

FORRESTAL CAMPUS, PRINCETON UNIVERSITY

Station: I 1

Monttoring Station location: Bee Brook

\begin{tabular}{|c|c|c|c|c|c|c|}
\hline FARAMETIR & $\begin{array}{l}1-22-86 \\
4: 20 \mathrm{PM} \\
\end{array}$ & $\begin{array}{l}2-24-86 \\
4: 50 \mathrm{PM} \\
\end{array}$ & $\begin{array}{l}3-18-86 \\
3: 20 \mathrm{PM}\end{array}$ & $\begin{array}{l}4-28-86 \\
11: 20 \mathrm{AM}\end{array}$ & $\begin{array}{l}5-27-86 \\
5: 00 \mathrm{PK}\end{array}$ & $\begin{array}{l}6-19-86 \\
12: 30 \mathrm{PAI}\end{array}$ \\
\hline Alkalinity, mg/l $\mathrm{CaCO}_{3} \mathrm{eq}$. & 4 & 8 & $\underline{8}$ & 12 & 14 & 66 \\
\hline $\mathrm{BOD}_{5} \mathrm{mg} / 1 \mathrm{o}_{7}$ & $s$ & 5 & $\leq$ & 5 & 1.5 & 2 \\
\hline Calcium Hardness, mg/l $\mathrm{CaCO}_{3} \mathrm{eq}$. & 12 & 16 & 24 & 8 & 8 & 60 \\
\hline Chromium - Total, mg/1 Cr & $<\quad .02$ & $\leqslant .02$ & $<.02$ & .02 & $\therefore .02$ & $\therefore .02$ \\
\hline Chromium - llexavalent, mg/1 Cr & $<.02$ & 5.02 & 5.02 & .02 & $<.02$ & $\therefore .02$ \\
\hline $\mathrm{COL}, \mathrm{mg} / 1 \mathrm{O}_{2}$ & 5 & 5 & 11 & 8 & 2.0 & 30 \\
\hline Copper, mg/l Cu & $\leq \quad .02$ & $5-.02$ & $\leq .02$ & .02 & $\leq .02$ & $\leq .02$ \\
\hline Di ssulved Oxygen, $\mathrm{mg} / 1$ az & 12.9 & 8.6 & 7.8 & 10.6 & 8.4 & 9.1 \\
\hline $\mathrm{EDTA}, \mathrm{mg} / 1 \mathrm{Cu} \mathrm{eq}$. & .06 & .07 & .06 & $.0 \vec{B}$ & $.07 \overline{8}$ & .062 \\
\hline Total Col iform Count, MIN/100 mI & 93 & 49 & 26 & 350 & $1 \overline{00}$ & 5 \\
\hline Flow, $\mathrm{fL}^{3} / \mathrm{sec}$ & .13 & .19 & .16 & .24 & .11 & .07 \\
\hline $\mathrm{Iron}, \mathrm{mg} / \mathrm{I} \mathrm{Fe}$ & .25 & .25 & .27 & .35 & $\leq . \overline{0} 2$ & .27 \\
\hline Nitrogen, Total kiedall, mg/1 N & 1.7 & .4 & .9 & .35 & 5.2 & .6 \\
\hline Nitrogen, Nitrate, mg/1 N & .71 & .1 & .29 & .41 &.$\overline{73}$ & .66 \\
\hline Oi L \& Grease, mg/I & .5 & .5 & .5 & .5 & $\leq .5$ & $\leq .5$ \\
\hline pll & 6.65 & 6.50 & 6.80 & 6.90 & 7.25 & 7.30 \\
\hline Phosphate Total $m_{i k} / 1$ P & 2 & 2 & .2 & .2 & $\leq .2$ & $\leq .2$ \\
\hline Phosphate, (titho mg/1 I & .2 & .2 & .2 & 5 & $\because .2$ & $<. \overline{2}$ \\
\hline Solids - Djssolved, ng/1 & 121 & 129 & B8 & 75 & 114 & 186 \\
\hline Sol ids - Suspended $\mathrm{mg} / 1$ & $<$ & $i$ & 6 & 1 & 24 & 1 \\
\hline Sulfale, $\mathrm{mg}_{\mathrm{g}} / \mathrm{SO}$ & 22 & 19 & 18 & 19 & 18 & 29 \\
\hline Temperature, ${ }^{\circ} \mathrm{C}$ & 5.5 & 5 & 10 & 15,8 & 200 & 16.5 \\
\hline Turbidity, NTu & 7.8 & 3.6 & 2.8 & 3.6 & 3.6 & 8.9 \\
\hline 2ins $\mathrm{mg} / 12 n$ & .02 & .03 & .02 & .02 & $<.01$ & .01 \\
\hline Elaris & S1.cloudy & Clear & clear & si. cloudy & S1. Clolidy & Gilear \\
\hline
\end{tabular}


T'ABLEE 14 (cont'd)

WATER QUALITY MONITORING DATA

FORRESTAL CAMPUS, PRINCETON UNIVERSITY

Station: B 1

Monitoring Station Location: Bee Brook

\begin{tabular}{|c|c|c|c|c|c|c|}
\hline PARAMETER & $\begin{array}{l}7-22-86 \\
12: 45 \text { PM }\end{array}$ & $\begin{array}{l}8-20-86 \\
2: 00 \mathrm{PA} \\
\end{array}$ & $\begin{array}{l}9-22-86 \\
1.45 \quad 14 \\
\end{array}$ & $\begin{array}{l}10-20-86 \\
1: 20 \mathrm{PM}\end{array}$ & $\begin{array}{l}11-18-86 \\
12: 35 \text { PM }\end{array}$ & $\begin{array}{l}12-23-86 \\
12: 50 \quad P 31 \\
\end{array}$ \\
\hline Alkalinity, mg/l CaCO3 eq. & 30 & 50 & 48 & 60 & 22 & 10 \\
\hline $\mathrm{BOD} 5 \mathrm{mg} / 1$ o, & 1.2 & 1.3 & 1.4 & रा & 2.2 & 1.2 \\
\hline Calcium llardness, mg/1 $\mathrm{CaCO}_{3}$ eq. & 32 & 44. & 40 & 36 & 40 & 32 \\
\hline Chromium - Total, $\mathrm{mg} / \mathrm{l} \mathrm{Cr}$ & $<.02$ & 5.02 & $\leq .02$ & $<.02$ & $<, 02$ & 5.03 \\
\hline Chromium - Mexavalent, mg/1 Cr & $\leq .02$ & 5.02 & $\leq .02$ & 5.02 & $\leq, 02$ & $<.92$ \\
\hline $\mathrm{COD}, \mathrm{mg} / 1 \quad \mathrm{O}_{2}$ & 19 & $2 \%$ & 5,0 & 12.5 & 22 & 17 \\
\hline Copper, mg/l Cu & $\leq .02$ & 5,02 & $5,0.2$ & $\leq .02$ & $<.02$ & .01 \\
\hline Dissolved Oxygen, mg/1 on & 6.2 & 7.8 & 6.8 & 8.5 & 8,8 & 14,0 \\
\hline EDl'A, mg/l Cu eq. & .05 & .06 & .114 & .046 & .06 & $\ldots 17$. \\
\hline Total Col iform Count, MPN/100 mL & 400 & 1600 & $\geq 2.400$ & 340 & 170 & - I8II \\
\hline Fluw, flo/sec & .067 & .055 & 0062 & .05 & .07 & .16 \\
\hline $\mathrm{Iron}, \mathrm{ing} / \mathrm{l} \mathrm{Fe}$ & .17 & .44 & .012 & .14 & .77 & .24 \\
\hline Nitrogen, Tulal Kjedahl, mg/1 N & .4 & 2 & L. & .5 & (1) & 5.1 \\
\hline Nitrogen, Nitrate, $\mathrm{mg} / 1 \mathrm{~N}$ & .24 & .103 & .38 & 1.06 & 5.1 & 8.8 \\
\hline $011 \&$ Grease, $\mathrm{mg} / 1$ & $<.5$ & 5.5 & 5. & $<.5$ & $<.5$ & $<.5$ \\
\hline $\mathrm{pH}$ & 6.65 & 7.65 & 6.55 & 7.25 & 6.50 & 6.75. \\
\hline Phosphate, Total mg/l p & $\leq .2$ & $<.2$ & 5.2 & .5 & $\leq .2$ & $<.2$ \\
\hline Phosphate, Ortho nig/L P & $<.2$ & $<.2$ & $<$ & .4 & $\leq 2$ & $<2$ \\
\hline Solids - Dissolved, $\mathrm{mg} / \mathrm{l}$ & 151 & 175 & U1 & 168 & 96 & 73 \\
\hline Solids - Suspended, $n \mathrm{~g} / 1$ & 1 & 1 & 4 & 2 & $<1$ & 12 \\
\hline Sulrate, Iig/ $1 \mathrm{SO}_{4}$ & 21 & 17.2 & 24. & ji) & 34 & 21 \\
\hline Fenuperalure, & $22.3^{\circ} \mathrm{C}$ & 21,0 & $16.0^{\circ} \mathrm{C}$ & 10.5 & 8.11 & 3.0 \\
\hline ?urbidity, NiU & 3.4 & 2.1 & 2,3 & +6 & 2.2 & 2.4 \\
\hline$\overline{\mathrm{inc}}, \mathrm{mg} / \mathrm{l} \mathrm{Zn}_{\mathrm{n}}$ & .03 & .02 & 02 & .03 & .025 & ..111 \\
\hline Clarity & SI.Cloudy & Clear & Silpar & Gilear & SL. (ilumely & Cilears \\
\hline
\end{tabular}


TABLE 15

WATER QUALI'Y MONITORING DATA FORRESTAL CAMIPIS, PRINCETON UNIVERSITY

Station: B 2

Monitoring Station location: Bee Brook

PARAMETER

$1-22-86$

$2-24-86$

$3-18-86$

$4-28-86$ $5-27-86$ 6-19-86

Alkalinity, $\mathrm{mg} / 1 \mathrm{CaCO} 3 \mathrm{eq}$.

Boplo ing / o?

Calcium llardness, $\mathrm{ng} / 1 \mathrm{CaCO} 3 \mathrm{eq}$.

Chroníum, Tota1, mg/1 $\mathrm{Cr}$

Chromium, llexavalent, $\mathrm{mg} / 1 \mathrm{Cr}$

COD, mg/1_o2

Copper, $\mathrm{mg} / 1 \mathrm{Cu}$

Dissolved Oxygen, mg/1 o2

EDTA, mg/l Cu eq.

Total Coli form Count, NPN/100 m1

Flow, $\mathrm{ft}^{3} / \mathrm{sec}$

Iron $m g / 1 \mathrm{Fe}$

Nitrogen, Total K jedahl, ma/l N

Nitrate, mg/l N

0i1 \& Grease, $m / 1$

nil

Phosphate, Total, mg/1 P

Phosphate, Ortho, mg/1 P

Solids, Dissolved, mo/1

Solids, Suspended, ing/ 1

Sulfate, $\mathrm{mg} / \mathrm{i} \mathrm{SO}_{4}$

Temperalure,

Tur idity NTl

Zinc, mg/I Zn

Clarity

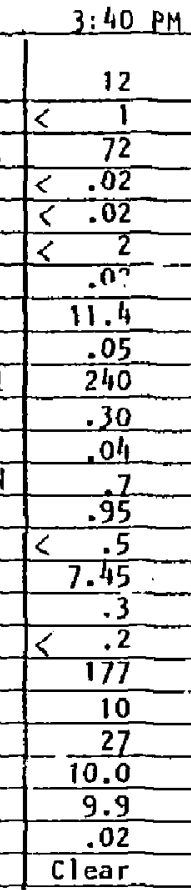

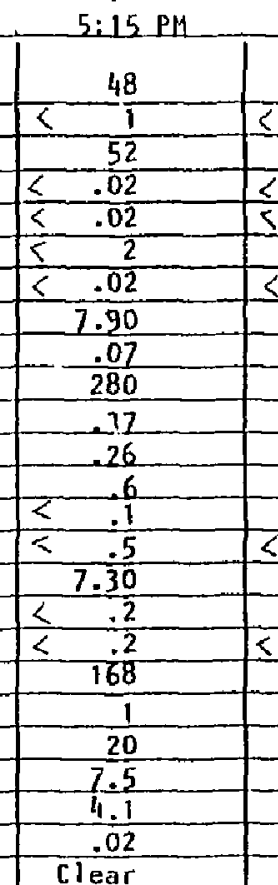
$10 \cdot 50-44$

\begin{tabular}{|c|c|}
\hline $\begin{array}{l}5-27-86 \\
4: 25 \text { PH }\end{array}$ & $\begin{array}{l}6-19-86 \\
11: 50 \ldots \text { AM }\end{array}$ \\
\hline 52 & 66 \\
\hline 1.1 & 323 \\
\hline 36 & 52 \\
\hline$\leq, 02$ & $\therefore .02$ \\
\hline$<.02$ & $<.02$ \\
\hline 13,0 & 15 \\
\hline$\leq .02$ & 5.02 \\
\hline 8.6 & 8.9 \\
\hline .05 & .059 \\
\hline 460 & 130 \\
\hline .31 & .28 \\
\hline .13 & .15 \\
\hline$\leq .2$ & .4 \\
\hline .89 & .80 \\
\hline$<.5$ & $<.5$ \\
\hline 2.25 & 7.10 \\
\hline 3 & .5 \\
\hline .2 & .4 \\
\hline 143 & 178 \\
\hline 20 & $<1$ \\
\hline 19 & 25 \\
\hline 20.9 & 21.0 \\
\hline 3.1 & 3.6 \\
\hline .01 & .02 \\
\hline 5l.Cloudy & 51. Ciloudy \\
\hline
\end{tabular}


TABLE 15 (cont'd)

WATER QULALITY MNITORING DATA FORRESTAL CAMIPUS, PRLNCETON UNIVERSITY

Station: B 2

Monitoring Station Location: Bee Brook

\begin{tabular}{|c|c|c|c|c|c|c|}
\hline PARAPETER & $\begin{array}{l}7-22-86 \\
12: 00 \text { PM } \\
\end{array}$ & $\begin{array}{l}8-20-86 \\
1: 25 \mathrm{PM} \\
\end{array}$ & $\begin{array}{l}9-22-86 \\
1: 20 \quad 1 M\end{array}$ & $\begin{array}{l}10-20-86 \\
12: 31) 15 ! \\
\end{array}$ & $\begin{array}{l}11-18-86 \\
11: 50 \mathrm{AM}\end{array}$ & $\begin{array}{l}12-22-86 \\
12: 30\end{array}$ \\
\hline Alkalinity, $\mathrm{mg} / 1 \mathrm{CaCO}_{3} \mathrm{eq}$. & 60 & 60 & 100 & 76 & 48 & 44 \\
\hline $\mathrm{BOD}_{5} \mathrm{mg} / \mathrm{l}$ on & 51 & 1.7 & $<1$ & 51 & 1.4 & 1.6 \\
\hline Calcium llardness, mg/ $1 \mathrm{CaCO}_{3} \mathrm{eq}$. & 56 & 96 & (1) & 48 & 80 & 88 \\
\hline Chromium, Total, mg/l Cr & 5.02 & $<.02$ & $<.02$ & $\leq .02$ & 2.02 & 5.02 \\
\hline Clironium, llexavalent, mg/1 Cr & $S .02$ & 5.02 & 5.02 & $<.02$ & 5.02 & 6.02 \\
\hline $\mathrm{COD}, \pi \mathrm{gg} / \mathrm{1}-2$ & 10 & 13 & 15 & 12.5 & 0.5 & 17 \\
\hline Copper, mg/1 Cu & $\leq .02$ & .02 & 5.02 & $<.02$ & 5.112 & .112 \\
\hline Dissolved Oxygen, mg/l oz & 8.1 & 8.4 & $3 . \overline{8}$ & 9.6 & 11.3 & 12,6 \\
\hline EDTA, mg/1 Gu eq. & .05 & .07 & .04 & 049 & .05 & 07 \\
\hline Total Coli form Count, MNN/100 ml & $\geq 2400$ & 920 & 22,400 & 1600 & 21 & 49 \\
\hline Flow, $\mathrm{f} \mathrm{t} / \mathrm{sec}$ & 423 & .2014 & .350 & .23 & .37 & 35 \\
\hline Iron, ang/1 lie & .17 & .29 & 2.28 & 17 & 27 & .40 \\
\hline 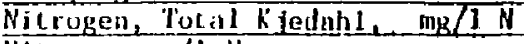 & +2 & .5 & .6 & .3 & -6 & 5,1 \\
\hline Mitrate, ne/1 N & 16 & .25 & .73 & 1,1 & .15 & 1,3 \\
\hline Oil \& Grease $\mathrm{mg} / 1$ & 5,5 & $\leq .5$ & .3 & $<.5$ & 6.5 & 5.5 \\
\hline DII & 2.65 & 7.75 & 6.95 & 7.4 & 7.65 & 7,45 \\
\hline Phosphate, Total, mg/L P & -5 & .7 & .9 & .4 & .5 & 5.2 \\
\hline Plosphate, Orcho, mg/L P & -14 & .6 & .45 & .4 & 3 & $\leq 2$ \\
\hline Solids, Dissolved, mg/l & 165 & 254 & 155 & 149 & 122 & 128 \\
\hline Bulids, Suspended, mg/1 & 2 & $<1$ & 2 & 1 & 1 & 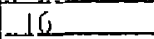 \\
\hline Sulface, $\mathrm{mg} / \mathrm{I} \mathrm{SO}_{4}$ & 22 & 69 & 36 & 30 & 22 & .21 \\
\hline Temperat ure, ${ }^{2} \bar{C}$ & $24.0^{\circ} \mathrm{C}$ & 23.11 & 20.0 & 17.1 & 12.0 & 0,0 \\
\hline TurbiliLy, NTU & 3.2 & 1.9 & 29 & 3.11 & -4.5 & 12 \\
\hline 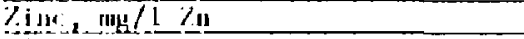 & (1) & .112 & .114 & .112 & 421 & 113 \\
\hline Elatisy & Gilcait & C.I cuas & Mud Giondy & (C):11! & ij_tidity & $\because !$ C.I (1)11 \\
\hline
\end{tabular}


TABLE 16

WATER QUALITY MONIJORING DATA

FORRESTAL CARPUS, PRINCETON UNIVERSITY

Station: C 1

Monitoring Station location: Delaware Raritan Center

\begin{tabular}{|c|c|c|c|c|c|c|}
\hline PARAMETER & $\begin{array}{r}1-22-86 \\
4: 45 P M \\
\end{array}$ & $\begin{array}{l}2-24-86 \\
4: 10 P M \\
\end{array}$ & $\begin{array}{l}3-18-86 \\
2: 05 \quad P M \\
\end{array}$ & $\begin{array}{l}4-28-86 \\
10: 35 \mathrm{AM}\end{array}$ & $\begin{array}{l}5-27-86 \\
4: 40 P M\end{array}$ & $\begin{array}{l}6-19-86 \\
3: 40 \quad 1 P 4 \\
\end{array}$ \\
\hline Alkalinily, $\mathrm{mg} / 1 \mathrm{CaCO}_{3} \mathrm{el}$. & 10 & 18 & 22 & 22 & 22 & 36 \\
\hline Calciur Ilardness, mg/1 $\mathrm{CaCO}_{3}$ eq. & 68 & 28 & 40 & 1,4 & 24 & 40 \\
\hline Chromium, Total, mg $/ 1 \mathrm{Cr}$ & $<.02$ & $<.02$ & $\leq .02$ & $<.02$ & $\leq .02$ & $<.02$ \\
\hline Ghromium, llexavalent, mg/1 $\mathrm{Cr}$ & $<.0 ?$ & $<.02$ & 5.02 & $<.02$ & $\leqslant \quad .02$ & $<.02$ \\
\hline Copuer, $\mathrm{mg} / \mathrm{l} \mathrm{Cu}$ & $<.02$ & $<.02$ & $<.02$ & $\leq .02$ & $\leq .02$ & $<.02$ \\
\hline Iron, $\mathrm{og} / 1 \mathrm{Fe}$ & .40 & .36 & 1.66 & .99 & .34 & .26 \\
\hline Nitrate, $m / 1 \mathrm{~N}$ & +78 & -.57 & .40 & .66 & .98 & .85 \\
\hline Qil and Grease, mg $/ 1$ & $<.5$ & $\leq .5$ & 5.5 & $\leq .5$ & $\leq .5$ & .7 \\
\hline pll & 6.90 & 6.70 & 6.30 & 6.80 & 6.85 & 1.75 \\
\hline Phosplate, Tatal, mg/I P & $\leq .2$ & $<.2$ & $\leq .2$ & $\leq .2$ & .2 & $\zeta .2$ \\
\hline Sulfate, mg/1 SO 4 & 27 & 19 & 28 & 23 & 18 & 20 \\
\hline Turbirlity, Nlu & 7.8 & 10.5 & 22 & 12 & 6.7 & 8.7 \\
\hline $2 \mathrm{inc}, \mathrm{mg} / 1 \mathrm{Zn}$ & .05 & .02 & .04 & .03 & .02 & .02 \\
\hline ciaricy & S1. Cloud & sl. Cloud & S1 Clolu & 51. Cloudy & S1. Cloudy & S1. Cloundy \\
\hline
\end{tabular}


TABLE 16 (cont ${ }^{\prime} d$ )

WATER QUALI'Y'Y MONITORING DATA

FORRESTAL CAMIPUS, PRINCETON UNTVERSIIY

Station: C 1

Monitoring Station I,ocation: Delaware Raritan Center

\begin{tabular}{|c|c|c|c|c|c|c|}
\hline PARAMETER & $\begin{array}{l}7-22-86 \\
12: 00 \mathrm{IM}\end{array}$ & $\begin{array}{l}8-20-86 \\
2: 15 \mathrm{PM} \\
\end{array}$ & $\begin{array}{l}9-22-86 \\
2: 30 \mathrm{PH}\end{array}$ & $\begin{array}{l}10-20-80 \\
10: 05 \mathrm{AM}\end{array}$ & $\begin{array}{l}11-18-86 \\
10: 26 \mathrm{AM}\end{array}$ & $\begin{array}{l}12-22-86 \\
12: 50 \mathrm{PH}\end{array}$ \\
\hline Alkalinity, $\mathrm{m}_{2} / \mathrm{CaCO} \mathrm{Cl}_{3}$. & 38 & 40 & 36 & 38 & 32 & $3(1)$ \\
\hline Calcium llariness, mg/l $\mathrm{CaCO}_{3}$ eq. & 32 & 40 & 48 & 48 & 56 & 76 \\
\hline Chromium, Total, mR/1 Cr & $\leq .02$ & $\leq .02$ & $\leq .192$ & $<.012$ & 6.012 & $\leq .02$ \\
\hline Chruntuin, llexavalent, $\mathrm{mg} / \mathrm{l} \mathrm{Cr}$ & 5.02 & $\leq .02$ & $\leq .012$ & $<.112$ & 5.02 & $<.02$ \\
\hline Copper, $m g / 1 \mathrm{Cu}$ & $<.02$ & $\langle .02$ & $\leq .112$ & $\leq .02$ & 6.112 & .13 \\
\hline EDTA mg/l cu eq. & .03 & .06 & .03 & .041 & .05 & .199 \\
\hline Iron, mg/L Fe & 1.04 & 3.18 & 1.13 & .36 & .24 & .53 \\
\hline Nitrate, mg/l $\mathrm{N}$ & 18 & .103 & 2.03 & 1.06 & .10 & 1.5 \\
\hline Oil and Lrease, nug/1 & $S, 5$ & $<.5$ & $\leq .5$ & $<.5$ & 6.5 & 6.5 \\
\hline pll. & 7.55 & 7.25 & 7.115 & 7.25 & 7.35 & 7.25 \\
\hline P'hosplanle, folal, mg/1 P & $<.2$ & $<.2$ & $<.2$ & 5.2 & $<.2$ & $<.2$ \\
\hline Plosplidere, Orqlio, $\mathrm{mg} / \mathrm{t}$ & $<.2$ & $<.2$ & $\leq .2$ & $\leqslant .2$ & $<.2$ & 5.2 \\
\hline Solids, bissolved, mg/I & 137 & $100^{\circ}$ & 135 & 115 & 913 & 125 \\
\hline Solits, Suspended, mo/l & 1 & 1 & 1 & 2 & 3 & 16 \\
\hline Sillinle, mg/1 SO 4 & 20 & 16.2 & 26 & 27 & 23 & 29) \\
\hline Fingiality, Nlu & 18 & $2.1)$ & 17 & 5.9 & 3.7 & 12 \\
\hline linc $\operatorname{mg} / 17 n$ & .02 & .012 & 5.01 & .012 & .1119 & .20 \\
\hline t:1a1 ity. & Misl c:louly & SI C:Inuly & il (:Immly & i. $\quad$ r:1 oumly & S: Cilomily & S1. (:Imolity \\
\hline
\end{tabular}


TABLE 17

WATER QUALIIY MONITORINC; DATA FORRESTAL CIMIUS; PRINCETON UNIVERSITY

Station: D1

Monitoring Station Location: Drainage Ditcli

\begin{tabular}{|c|c|c|c|c|c|c|}
\hline PARANEIER & $\begin{array}{l}1-22-86 \\
11: 30 \text { AM }\end{array}$ & $\begin{array}{l}2-24-86 \\
1: 40 . P M\end{array}$ & $\begin{array}{l}3-18-86 \\
\mathrm{~L}: 50 . \mathrm{eM}\end{array}$ & $\begin{array}{l}4-28-86 \\
10: 25 \text { AM }\end{array}$ & $\begin{array}{l}5-77-R 6 \\
3: 45 P M\end{array}$ & $12 ! 9^{6} \overline{0}^{8} \mathrm{M}_{\mathrm{M}}$ \\
\hline Alkalinity, $\mathrm{mg} / 1 \mathrm{CaCO} 3 \mathrm{eq}$. & 10 & 22 & 24 & 22 & 28 & 30 \\
\hline $\mathrm{BOD}_{5} \mathrm{mg} / \mathrm{l} \quad \mathrm{O}_{2}$ & $\dot{s}$ & $\leq$ & $<$ & 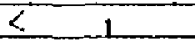 & 1.7 & 2.6 \\
\hline Calcium llardness, $\mathrm{mg} / \mathrm{l} \mathrm{CaCO}$; en. & 60 & 40 & 48 & 32 & 28 & 44 \\
\hline Chroni um, Total, mg/1 Cr & 02 & $5 \quad 02$ & 03 & $\therefore \quad 02$ & $<.02$ & $<.02$ \\
\hline Chromi um, Ilexavalent, mg/1 $\mathrm{Cr}$ & 5.02 & $\leq .02$ & $<\quad 02$ & $<\quad 02$ & $<.02$ & $<.02$ \\
\hline$\overline{\mathrm{COD}}, \mathrm{mg} / \mathrm{l}$ or & $<\quad 2$ & $5 \quad 2$ & 11 & $<$ & 15 & 23 \\
\hline Copuer, mg/l Cu & .02 & $\leq .02$ & $6 \quad .02$ & .03 & $<.02$ & 5.02 \\
\hline Dissolved Oxygen, $\mathrm{mg} / 1$ o2 & 11.2 & 7.30 & 6.55 & 9.60 & 7.8 & 7.8 \\
\hline EDId, mg/l cu en & .05 & .06 & .04 & .09 & .051 & $.03 \overline{4}$ \\
\hline Tuta Coliform Count, MPN/100 ml & 63 & & 4 & 21 & 43 & 350 \\
\hline low, $\mathrm{Et}^{3} / \mathrm{sec}$ & .05 & .09 & .05 & .07 & .07 & .06 \\
\hline Irrn, $\mathrm{mg} / \mathrm{I}$ Fe & .18 & .25 & 1.62 & .83 & .15 & .13 \\
\hline $\begin{array}{l}\text { Nitropen: } \\
\text { Total Kiedahl } \mathrm{mg} / 1 \mathrm{~N}\end{array}$ & 3 & .3 & 1 & .4 & 1.3 & .8 \\
\hline Nitrate, mg/i $\mathrm{N}$ & 1.2 & & .59 & .82 & 1.1 & .86 \\
\hline $0 \mathrm{i} 1$ \& Grease, ma/l & 5.5 & $<\quad .5$ & & & $\div .5$ & $<.5$ \\
\hline$\overline{2} 11$ & 7.15 & 7.35 & 6.85 & 6.75 & 7.15 & 7.10 \\
\hline Phosphate, Total. me/1 $\mathrm{P}$ & .8 & $<\quad .2$ & .6 & .9 & .6 & .6 \\
\hline Phosphate, Ortho, mg/1 P & .4 & .2 & .3 &.$\overline{3}$ & .4 & .4 \\
\hline Solids, Dissolved, mg/l & 178 & 17 & 160 & 136 & 152 & 154 \\
\hline Solids, Suspended, $\mathrm{mg} / \mathrm{l}$ & 23 & 3 & 25 & 8 & 31 & 51 \\
\hline Sulfate, mg/1 50 & 2) & 20 & 22 & $\overline{2} \overline{3}$ & 21 & 21 \\
\hline Temperature, ${ }^{\circ} \mathrm{C}$ & $\pi .0$ & 10.5 & 11.5 & 15.3 & 18.5 & 22.5 \\
\hline Turdidily, NitU & 25 & 8.3 & 20 & 11 & 4.3 & 4.11 \\
\hline $2 \mathrm{inc}, \mathrm{mg} / \mathrm{l} 2 \mathrm{n}$ & .04 & .05 & .05 & .03 & .02 & .01 \\
\hline (:1arity & Mod.CToudy & SI. Cloudy & 51. Cloudy & 51. cloudy & Mod.cla & S1. L.1.nuly \\
\hline
\end{tabular}


TABLE 17 ( cont $\left.^{\prime} \mathrm{d}\right)$

WATER QUJALITY MONITORING DATA

FORRESTAL CAMPUS, PRTMGETON UNIVERSITY

Station: D1

Monitoring Station Location: Drainage Ditch

\begin{tabular}{|c|c|c|c|c|c|c|}
\hline PARAMEIER & $\begin{array}{l}7-22-86 \\
2: 00 \text { Nㅐ }\end{array}$ & $\begin{array}{l}8-20-86 \\
12: 0019\end{array}$ & $\begin{array}{l}9-22-86 \\
12: 50 \text { 1N } \\
\end{array}$ & $\begin{array}{l}10-20-86 \\
11: 35 \mathrm{AM} \\
\end{array}$ & $\begin{array}{l}11-18-86 \\
10: 35 \text { AN }\end{array}$ & $\begin{array}{l}12-22-H 6 \\
11: 50 A M\end{array}$ \\
\hline Alkalinity, $\mathrm{mg} / 1 \mathrm{CaCO}_{3} \mathrm{eq}$. & 38 & 38 & 38 & 40 & 34 & 30 \\
\hline $\mathrm{B} O \mathrm{D}_{\mathrm{c}} \mathrm{mg} / \mathrm{l} \quad \mathrm{Q}_{2}$ & 2.6 & 5.9 & $<1$ & $\leq 1$ & $\perp$ & 10 \\
\hline Calc um llardness, $\mathrm{mg} / 1 \mathrm{CaCO}_{3} \in \mathrm{e}$. & 32 & 40 & 52 & 40 & 58 & 64 \\
\hline Cliromium, Tolal, $\mathrm{mg} / 1 \mathrm{Cr}$ & $\leq .02$ & 5.12 & $<.02$ & $\leq .112$ & 5.02 & $<02$ \\
\hline Cliruini un, Hexavalent, $\mathrm{mg} / 1 \mathrm{Cr}$ & $<.02$ & र.02 & 6.112 & .5 .12 & $<.42$ & 5.112 \\
\hline (Ol), $\mathrm{mg} / 1$ on & 10 & 40 & 9.11 & 12.5 & 0.5 & 0.11 \\
\hline Copper, mg/1 Cu & $<.02$ & $\leq .02$ & 5.112 & $<.02$ & 5.12 & (U) \\
\hline Dissolved Oxygen, mg/1 o2 & 6.8 & 7.1 & 8.8 & -9.5 & 10.8 & 11.3 \\
\hline EDTA, mg/l Cu eq & .04 & .06 & .015 & .0 tij & .04 & .09 \\
\hline Iotal Coliform Count, $M P N / 100 \mathrm{ml}$ & $46 ! \overline{0}$ & 540 & 20 & $<2$ & $<2$ & 52 \\
\hline Flow, $\mathrm{ft}^{3} / \mathrm{sec}$ & .051 & .055 & .095 & .06 & .11 & $\sqrt{2}$ \\
\hline Iron, $\mathrm{mg} / \mathrm{l} \mathrm{Fe}$ & .26 & $.4 \overline{3}$ & 1.44 & .27 & 1.2 & 47 \\
\hline $\begin{array}{l}\text { Nitrogen: } \\
\text { Total Kjedahl, mg/1 N }\end{array}$ & $<.2$ & .5 & .8 & .6 & 25 & 9 \\
\hline Nitrate, mg/l N & .17 & $<.1$ & .55 & 2.0 & .28 & 1.7 \\
\hline 0i.1 \& Grease, mg/l & 5.5 & 5.5 & $\leq .5$ & $<.5$ & $<.5$ & $<.5$ \\
\hline pll & 7.25 & 7.45 & 6.85 & 7.4 & 7.35 & 7.15 \\
\hline Thosuliale, Total $9 g^{\prime} 1$ P & .6 & .5 & .8 & .5 & .625 & 2 \\
\hline Phosplince, Ortho, mg/l p & .4 & .3 & .4 & .5 & .35 & 5.2 \\
\hline Solids, Dissolved, $\mathrm{mg} / \mathrm{I}$ & 151 & 105 & 132 & 112 & 08 & 111 \\
\hline Sulids, Suspended, $\mathrm{mg} / \mathrm{l}$ & 1 & 1 & 5 & 1 & 2 & 22 \\
\hline Sulfate, $\operatorname{lng} / \mathrm{l} \mathrm{SO}_{4}$ & 21 & 16.2 & 24 & 28 & 27 & 8.4 \\
\hline Toinjeralure, of & $25^{\circ} \mathrm{C}$ & 25.11 & 2.1 .0 & 18.11 & 11.5 & 9.0 \\
\hline lutbidicy, NiJ & 5.4 & 5.5 & 14 & 6.4 & 5.0 & 15 \\
\hline $7, \mathrm{inc}, \mathrm{mg} / 1 \mathrm{Ln}$ & .02 & .02 & $<.01$ & .114 & .22 & 24 \\
\hline Giarily & SI.C.Ioudy & SI. T.Toudy & Mosl. I:Isolaly & S1. (:10)idy & I:Irial & Eilcill \\
\hline
\end{tabular}


WITER QUALITY MONITORING DNTA FORRESTAL CANIUS, PRINCETON UNIVERSITY

Station: D 2

Monitori.ng Station Location: Drainage Ditch

\begin{tabular}{|c|c|c|c|c|c|c|}
\hline PARAMFTER & $\begin{array}{l}1-22-86 \\
4: 40 \quad P M \\
\end{array}$ & $\begin{array}{l}2-24-86 \\
2: 05 \mathrm{PM} \\
\end{array}$ & $\begin{array}{l}3-18-86 \\
12: 50 \mathrm{PM}\end{array}$ & $\begin{array}{l}4-28-86 \\
11: 35 \text { AM }\end{array}$ & $\begin{array}{l}5-27-86 \\
5: 15 P M\end{array}$ & $\begin{array}{l}6-19-86 \\
12: 50 \mathrm{PHL}\end{array}$ \\
\hline Alkalinitg $\mathrm{mg} / \mathrm{l} \mathrm{CaCO}, \mathrm{eq}$ & 18 & 66 & 66 & 64 & 60. & 64 \\
\hline B(O) $D_{c}$ mgli o2 & $\leq$ & $\leq$ & $\leq$ & $\leq$ & 2 & 2.6 \\
\hline Chromium, Total, $\mathrm{mg} / \mathrm{C} \mathrm{Cr}$ & $<.02$ & $\leq \quad .02$ & .05 & $<\quad 02$ & .02 & .02 \\
\hline Chromium, llexavalent, ma/1 Cr & 5.02 & $\leq, 02$ & $\leq \quad 02$ & 502 & .02 & $<.0 \overline{2}$ \\
\hline $\mathrm{COD}, \mathrm{mg} / 1 \mathrm{O}_{2}$ & $\leq$ & $<$ & 9.3 & $\leq \quad 2$ & 17 & 21 \\
\hline EIJTA, $\mathrm{mg} / 1 \mathrm{Cu}$ eq & .04 & .06 & .05 & .09 & .054 & .065 \\
\hline Total Coliform Count, MPN/ $\overline{100 \mathrm{ml}}$ & 240 & 240 & 350 & 170 & 93 & 280 \\
\hline Flow, ft $/ \mathrm{sec}$ & .18 & .21 & 31 & .23 & .15 & .14 \\
\hline Iron, mg/l Fe & .42 & .21 & 1.6 & 1.3 & .18 & .16 \\
\hline $\begin{array}{l}\text { Nitrogen: } \\
\text { Total } \mathrm{K} \text { jedahl, } \mathrm{mg} / 1 \mathrm{~N}\end{array}$ & .3 & 3 & 1.6 & 7 & 4 & .5 \\
\hline Mitrate, mg/1 N & .6 & .54 & .51 & .86 &. .72 & .58 \\
\hline Solids, Suspeuted, $\mathrm{mg} / 1$ & 4 & 1 & 5 & 11 & 22 & $\leq 1$ \\
\hline Sulfale, $\mathrm{mg} / 1 \mathrm{Sn} 4$ & 21 & 22 & 20 & 24 & 22 & 20 \\
\hline Temperature, "C & $\pi .7$ & $11 . \overline{3}$ & iाi. 0 & 17.0 & 20.7 & 22.0 \\
\hline Turbidity NTU & $\pi$ & 5.2 & 8.1 & 20 & 3.3 & 3.6 \\
\hline inc, mg/i $2 n$ & .03 & .04 & .01 & .02 & .01 & .02 \\
\hline Clarity & 5). Cloudr & clear & 51.5120 & SI _. Clo & 51, Clous & S1. $\{:\{1, \ldots$ \\
\hline
\end{tabular}


IABLE 18 (cont'd)

WATER QUALITY MONITORLAM; DATA FORRESTAL CAMPUS, PRINCEION UNIVERSIIY

Station: D 2

Monitoring Station Location: Drainage Ditch

\begin{tabular}{|c|c|c|c|c|c|c|}
\hline PARANEIER & $\begin{array}{l}7-22-86 \\
1: 05 \mathrm{PM} \\
\end{array}$ & $\begin{array}{l}8-20-80 \\
2: 30 \mathrm{PH} \\
\end{array}$ & $\begin{array}{l}9-22-86 \\
11: 501 \mathrm{M} \\
\end{array}$ & $\begin{array}{l}10-20-86 \\
10: 30 \mathrm{~A} M\end{array}$ & $\begin{array}{l}11-18-86 \\
12: 55 \mathrm{APl}\end{array}$ & $\begin{array}{l}12-22-86 \\
1: 15 \mathrm{HA}\end{array}$ \\
\hline Alkalinity, mg/l $\mathrm{CaCO}_{9}$ el & 46 & 58 & 48 & 52 & 48 & 56 \\
\hline $\mathrm{BOD}_{5} \mathrm{mg} / 1 \mathrm{o} 2$ & $\leq 1$ & 3.3 & $\leq 1$ & रा & $<1$ & $<1$ \\
\hline Calcium llardness, $\mathrm{mg} / 1 \mathrm{CaCO}_{3}$ eq & 44 & 56 & 56 & 40 & 76 & 70 \\
\hline Chromium, Total, mg/l Cr & $\leq .02$ & 5.02 & $\leq .02$ & $<.02$ & $\leq .02$ & 5.02 \\
\hline Grromium, Hexavalent, $\mathrm{mg} / 1 \mathrm{Cr}$ & $\angle .02$ & 5.02 & 5.02 & 5.12 & $\leq .02$ & 5.12 \\
\hline oud, $\mathrm{mg} / 1 \quad \mathrm{o}$, & 10 & 45 & $\leq 2.0$ & 5.0 & 3.5 & 12 \\
\hline Copper, mg/I $\bar{C} u$ & $<, 02$ & $\leqslant .02$ & $<.02$ & $\leq .02$ & $<.02$ & .03 \\
\hline Iissolved oxvgen, $\mathrm{mg} / 1 \mathrm{or}$ & 7.4 & 9.0 & 9.4 & 10.0 & 10.6 & 10.4 \\
\hline [iDTA, $\mathrm{mg} / 1$ Cu eúl & .04 & .07 & .06 & .041 & .015 & .05 \\
\hline Total Col iform Count, MPN/100 ml & $\geq 2400$ & 240 & 150 & 350 & 350 & 13 \\
\hline Flow, $\mathrm{fe} / \mathrm{sec}$ & .164 & .131 & .307 & .18 & .24 & 28 \\
\hline Iron, $\mathrm{mg} / \mathrm{l} \mathrm{Fe}$ & .30 & .31 & .88 & .50 & .84 & .54 \\
\hline $\begin{array}{l}\text { Nitrogen: } \\
\text { Total K jedahl, mg/i N }\end{array}$ & $\leq .2$ & .5 & .4 & .6 & .2 & $\therefore 1$ \\
\hline Nitrate. $\mathrm{mg} / \mathrm{l} \mathrm{N}$ & .19 & $<.1$ & .58 & 1.7 & .20 & 1,3 \\
\hline ()il \& Grease, $\mathrm{mg} / \mathrm{l}$ & $\zeta .5$ & 5.5 & $\leq .5$ & $<.5$ & $<.5$ & 5.5 \\
\hline ull & 7.25 & 7.55 & 7.50 & 7.4 & 7.65 & 745 \\
\hline Whosphate, Total, $\mathrm{mg} / \mathrm{l} \mathrm{P}$ & .3 & .3 & .7 & .4 & .5 & .2 \\
\hline Thosphate, Ortho, mg/l P & .3 & .2 & .3 & 4 & .3 & 5,2 \\
\hline Solids, Dissolved, mg/l & 151 & 149 & 151 & 142 & 124 & 143 \\
\hline Solids, Suspended, $\mathrm{mg} / \mathrm{l}$ & 2 & 1 & 1 & 3 & $\therefore$ & 19 \\
\hline Sulfale, mg/l SOL & 22 & 16.7 & 29 & 29 & 27 & 30 \\
\hline Temperat ure, 'C & $24.5^{\circ} \mathrm{C}$ & $2 \pi .5 \mathrm{C}$ & 21.0 & 16.75 & 12.1 & 111.0 \\
\hline Turbidity, NTU & 5.2 & 1.8 & 10 & 13 & 3.3 & 13 \\
\hline Zinc, mg/l 2n! & .013 & .03 & .01 & .04 & .20 & 14 \\
\hline Tarity & S1. Cloudy & Cilear & 51. Cloundy & S1. Clouily & S1. Silandy & S1. CIouny \\
\hline
\end{tabular}


TABLE 19

WATER QUALITY MONITORING DATA

FORRESTAL CAMPUS, PRINCETON UNIVERSITY

Station: E 1

Monitoring Station Location: Eltzabetitown Hater

\begin{tabular}{|c|c|c|c|c|c|c|}
\hline PAKAMEJER & $\begin{array}{l}1-22-86 \\
11: 15 \text { АM }\end{array}$ & $\begin{array}{l}2-24-86 \\
1: 30 \mathrm{PM} \\
\end{array}$ & $\begin{array}{l}3-18-86 \\
1: 30 \quad P M\end{array}$ & $\begin{array}{l}4-28-86 \\
10: 00 \text { AH. }\end{array}$ & $\begin{array}{l}5-27-86 \\
3: 35 \mathrm{PH}\end{array}$ & $\begin{array}{l}6-19-86 \\
10: 15 \mathrm{AM} \\
\end{array}$ \\
\hline Alkalinity 2 ig/1 $\mathrm{CaCO}_{3} \mathrm{eq}$. & 12 & 122 & 90 & 100 & 90. & 88 \\
\hline Calcium Hardness, mg/1 $\mathrm{CaCO} 3$ eg. & 56 & 128 & 128 & 120 & 76 & 108 \\
\hline Copper, mg/1 Cu & $\leq .02$ & $\leq .02$ & .03 & $\leq .02$ & $\leq .02$ & $\leq .02$ \\
\hline ToLal Culi form Count, MPN/I00 ml. & $<$ & $\leq$ & 2 & $\leq$ & $\leqslant 3$ & $\leq 2$ \\
\hline Iron, $\mathrm{mg} / 1 \mathrm{Fe}$ & .15 & $<.02$ & .09 & .08 & .12 & .14 \\
\hline Nitrogen, Total $\mathrm{mg} / \mathrm{l} \mathrm{N}$ & .5 & $\leq \quad .2$ & 1.1 & .3 & .3 & 5.2 \\
\hline Nitrate, $\mathrm{mg} / 1 \mathrm{NO} z$ & 2.2 & .6 & .49 & 2 & 2.0 & 1.2 \\
\hline pll & 6.90 & 7.35 & 7.15 & 7.05 & 6.95 & 7.20 \\
\hline Phospha's, Total, mo/1 P & .2 & $\leq \quad .2$ & .2 & $\leq \quad .2$ & $<. ?$ & $\leq .2$ \\
\hline Phusuliate, Ortho, $\mathrm{mg} / 1 \mathrm{P}$ & $<\quad .2$ & $<.2$ & $\leq .2$ & $\leq \quad .2$ & 5.2 & $\leq .2$ \\
\hline Manganese, mg/l Mn & 172 & .02 & .01 & .01 & $\leq .01$ & .02 \\
\hline Chloride, $\mathrm{mg} / \mathrm{l} \mathrm{Cl}$ & .02 & 21 & 24 & 23 & 24 & 25 \\
\hline Sol:ds $1 t_{1}$ gsolyed, ma/1 & 19 & 234 & 217 & 216 & 232 & 246 \\
\hline Sulfote, ng/1 $\mathrm{SO}$ & 29 & 30 & 25 & 27 & 31 & 39 \\
\hline Temper at ure, "c: & 8.0 & 9.0 & 11.0 & 13.0 & 15.0 & 19.5 \\
\hline 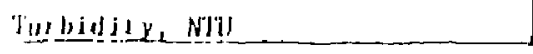 & .57 & 68 & -.25 & _. 46 & .35 & $\therefore$ \\
\hline
\end{tabular}


'ABIE 19 (cont'd)

WATER NUALITY MONITORING DATA FORRESTAL CAMPUS, PRINCETON UNIVERSITY

\section{Station: E 1}

Monicoring Station Location: Elizabethtown Water

\begin{tabular}{|c|c|c|c|c|c|c|}
\hline PARAMETER & $\begin{array}{l}7-22-86 \\
1: 45 \mathrm{PM} \\
\end{array}$ & $\begin{array}{l}8-20-86 \\
11: 25 \quad \mathrm{AM}\end{array}$ & $\begin{array}{l}9-22-86 \\
12: 301 \mathrm{MM}\end{array}$ & $\begin{array}{l}10-20-86 \\
11: 15 \mathrm{MM}\end{array}$ & $\begin{array}{l}11-18-86 \\
12: 55 \mathrm{AM}\end{array}$ & $\begin{array}{l}12-22-86 \\
11: 15 \mathrm{PM}\end{array}$ \\
\hline Alkalinity, mg/1 $\mathrm{CaCO}_{3} \mathrm{eq}$ & 18 & 82 & 84 & 84 & 120 & 34 \\
\hline Calcium llariness, mg/1 $\mathrm{CaCO}_{3}$ eq. & 96 & 88 & 44 & 36 & 140 & 100 \\
\hline Copper, mg/1 Cu & $<.02$ & $<.02$ & 5.02 & .04 & $<.02$ & -03 \\
\hline Potal Coliform Count, MPN/: 00 inl & $\leq 3$ & $\leq 2$ & $<3$ & $<2$ & $\leq 2$ & $<2$ \\
\hline Iron, $\mathrm{mg} / \mathrm{l} \mathrm{Fe}$ & .07 & .09 & .017 & .11 & .12 & .15 \\
\hline Nicrogen, lotal mg/1 $\mathrm{N}$ & $\leq, 2$ & .8 & .4 & .3 & .5 & 1.0 \\
\hline Nilrate, mg ${ }_{i}^{\prime 1} \mathrm{NO}_{3}$ & .28 & .13 & .31 & $\perp .4$ & 2.7 & 2.7 \\
\hline 嵎 & 7.05 & 7.20 & 6.65 & 7.4 & 7.40 & 7.25 \\
\hline Phosphate, Total, mg/1 P & $<.2$ & $\leq .2$ & $\leqslant ـ 2$ & $<.2$ & $\leq .2$ & $\leq .2$ \\
\hline Plosphate, Ortio, mg/l P & $<.2$ & $<.2$ & $<.2$ & $\leq .2$ & 6.2 & 5.2 \\
\hline Soldeds, Dissolved, $\mathrm{mg} / \mathrm{l}$ & 295 & 199 & 150 & 202 & 218 & 132 \\
\hline Manganese, ing/1 Mn & .01 & $<.01$ & .01 & $<.01$ & $\leq .01$ & .016 \\
\hline Gloride, $\mathrm{mg} / 1 \mathrm{cl}$ & 24 & 20 & 17 & 22 & 22 & 21 \\
\hline Silfale, mg/l $\mathrm{SO}_{4}$ & 71 & 28.3 & 30 & 59 & 54 & 46 \\
\hline Temperalue, ${ }^{\circ} \mathrm{C}$ & $20.0^{\circ} \mathrm{C}$ & $19.5^{\circ} \mathrm{C}$ & $17.5^{\circ} \mathrm{C}$ & 15.0 & 12.0 & 9.5 \\
\hline liubillity, N] & 1.4 & .30 & 50 & .36 & .54 & 1 \\
\hline
\end{tabular}


TABLE 20

WATER QUALITY MONITORING DATA

FORRESTAL CAMI'US, PRINCEION UNIVERSITY

Station: $\mathrm{P} 1$

Monitoring Station Location: Off-Site Location

\begin{tabular}{|c|c|c|c|c|c|c|}
\hline PARAMETER & $\begin{array}{l}1-22-86 \\
3: 50 \mathrm{PM} \\
\end{array}$ & $\begin{array}{l}2-24-86 \\
3: 15 P M\end{array}$ & $\begin{array}{l}3-18-86 \\
1: 25 \mathrm{PM} \\
\end{array}$ & $\begin{array}{l}4-28-86 \\
10: 00 \text { Al1 }\end{array}$ & $\begin{array}{r}5-27-86 \\
4: 00 \mathrm{PM} \\
\end{array}$ & $\begin{array}{l}6-19-86 \\
3: 00 \mathrm{PN} \\
\end{array}$ \\
\hline Alkalinity mg/1 $\mathrm{CaCO}_{3}$ eq. & 2 & 6 & 12 & 8 & 26 & 34 \\
\hline Calcium llaruness, $\mathrm{mg} / 1 \mathrm{CaCO}_{3}$ & 56 & 20 & 96. & 20 & 20 & 40 \\
\hline Chromium, Total, mg/l Cr & $<. .02$ & $<.02$ & $\leq .02$ & $\times \quad .02$ & $\div \quad .02$ & 5.0112 \\
\hline Chromium, llexavalent, $3 \mathrm{Bg} / \mathrm{C} \mathrm{Cr}$ & $<. .02$ & $<.02$ & $<.02$ & $\leqslant, 02$ & 5.02 & $<.02$ \\
\hline Copper, mg/1 $\mathrm{Cu}$ & $<.02$ & $<.02$ & $\leq .02$ & .02 & .02 & $<.02$ \\
\hline EDTA, $m g / 1 \mathrm{Cu} e q$. & .08 & .06 & .06 & .07 & .067 & .052 \\
\hline lron, $\mathrm{mg} / 1 \mathrm{Fg}$ & .32 & .75 & 1.18 & 1.64 & .44 & .53 \\
\hline Nitrate, mg/1 N & 1.9 & .58 & 1.1 & .65 & 1.3 & .58 \\
\hline Q i 1 and Grease, $\mathrm{mg} / 1$ & .5 & $\leq .5$ & $\leq .5$ & .5 & $\leq .5$ & $\therefore .5$ \\
\hline pll & 6.25 & 6.00 & 6.40 & 6.45 & 6.95 & 6.8 \\
\hline Pliosuliale, Tulal, mg/1 P & .2 & .2 & .2 & .2 & $\leqslant .2$ & $<.2$ \\
\hline Dlosphate, ortho, mu/l P & $\leq$ & .2 & .2 & .2 & $\therefore .2$ & $\leq .2$ \\
\hline Soljds, Dissolved & 141 & 130 & 103 & 78 & 80 & 134 \\
\hline Solids, Suspended, mg/1 & 1 & 21 & 7 & 1 & 26 & 2 \\
\hline Sulfate, mg/I SOL & 27 & 17 & 19 & 23 & 16 & 15 \\
\hline Jurbitity, Nlu & 7.8 & 17 & 8.6 & 16 & 7.9 & 5.8 \\
\hline Zinc & .05 & .03 & .02 & .02 & .02 & .12 \\
\hline claricy & S1. Cloudr & Mod, cloudy & clear & Mod. Cloudy & Clcar & SI.ciloudy \\
\hline
\end{tabular}




\section{TABLE 20 (cont'd)}

WATER QUALITY MONITORING DATA

FORRESTAL CAMIPUS, PRINCETON UNIVERSITY

Station: $P 1$

Monitoring Station Location: Off-Site Location

\begin{tabular}{|c|c|c|c|c|c|c|}
\hline PARANETER & $\begin{array}{l}7-22-86 \\
11: 20 \mathrm{AM}\end{array}$ & $\begin{array}{l}8-20-86 \\
1: 15 \mathrm{PM} \\
\end{array}$ & $\begin{array}{l}9-2 \cdot 2-86 \\
1: 50 \quad 1 M 4\end{array}$ & $\begin{array}{l}10-20-86 \\
9: 15 \text { AN } \\
\end{array}$ & $\begin{array}{l}11-18-86 \\
9.35 \mathrm{AM} \\
\end{array}$ & $\begin{array}{l}12-22-86 \\
12: 10 \quad[\mathrm{M} \\
\end{array}$ \\
\hline Alkalinity, mg/l $\mathrm{CaCO}_{3} \mathrm{eq}$. & 30 & 16 & 16 & 20 & 14 & 8 \\
\hline Calcium llardness, mg/1 CaCo2 & 24 & 20 & 32 & 56 & 44 & 36 \\
\hline Shromium, Tolal, mg/l Cr & $<.02$ & $\leq .02$ & $<.02$ & 6.02 & $\leq .112$ & $<.02$ \\
\hline Chrumi um, Hexavalent, $\mathrm{mg} / \mathrm{l} \mathrm{Cr}$ & 5.02 & $<.02$ & $<.02$ & $<.1 ?$ & 5.012 & $<.032$ \\
\hline Copper, mg/l Cu & $<.02$ & $<.02$ & 5.02 & .02 & $<.02$ & $<.012$ \\
\hline EDTA $1 . \mathrm{mg} / \mathrm{l} \mathrm{Cu}$ eq. & .04 & .04 & .04 & .068 & .015 & .05 \\
\hline Iron, mg/l $\mathrm{Fe}$ & 1.05 . & 2.29 & 1.42 & .85 & .67 & 1.07 \\
\hline Nitrate, mg/l $\mathrm{N}$ & 26 & $<.1$ & 1.8 & .63 & .95 & 1.3 \\
\hline Dil and Grease, mg/l & $<.5$ & $<.5$ & $<.5$ & $\leq .5$ & $\leq .5$ & $<.5$ \\
\hline pill & 7.10 & 6.65 & 6.65 & 6.8 & 6.70 & 6,50 \\
\hline Plysphiste, lotal, $\mathrm{mg} / \mathrm{l}$ p & $\zeta .2$ & $\leq .2$ & 5.2 & $<.2$ & 5.2 & $\leq .2$ \\
\hline Phosphace, Ortho, mg/le & $<.2$ & $<.2$ & $<.2$ & $<.2$ & 6.2 & $<.2$ \\
\hline Solids, Dissolved & 138 & 92 & 81 & 94 & 97 & 81 \\
\hline Sol $\mathrm{jals}$, Suspended, mg/1 & $\leq 1$ & 1 & 6 & 3 & 2 & 36 \\
\hline ulate, mg/1 SO4 & 11 & 12.5 & 11 & 23 & 12 & 23 \\
\hline lutballiLy, NiU & 5,8 & 3.7 & 4.9 & 4.3 & 5.6 & 27 \\
\hline Zins: & .02 & .011 & $\therefore .01$ & .01 & .012 & .112 \\
\hline liarity & SI. Clomily & S1.c1omily & Si. Sitounly & S1. Cilumdy & S1. Cixominy & Plombral on y 6.1 \\
\hline
\end{tabular}




\section{WATER QUALITY MONITORING DATA}

FORRESTAL CAMPUS, PRINCETON UNIVERSITY

\section{Station: $\mathbf{P} 2$}

Monitaring Station location: Off-Site location

\begin{tabular}{|c|c|c|c|c|c|c|}
\hline PARAMETER & $\begin{array}{l}1-22-86 \\
4: 15 P H\end{array}$ & $\begin{array}{l}2-24-86 \\
3: 40 \mathrm{PH}\end{array}$ & $\begin{array}{l}3-18-86 \\
1: 45 \text { PA } \\
\end{array}$ & $\begin{array}{l}4-28-86 \\
10.20 \mathrm{AM}\end{array}$ & $\begin{array}{l}5-27-86 \\
4: 20 \mathrm{PM}\end{array}$ & $\begin{array}{l}6-19-86 \\
3: 20 \quad 13 \\
\end{array}$ \\
\hline AlkaIinily, mg/l CaCO $\mathrm{Cl}_{3}$ ed: & 2 & 6 & B & 10 & 20 & 28 \\
\hline Calcium larluess, mo/l $\mathrm{CaCO}_{3}$ en & 44 & 4 & $I_{1} I_{1}$ & 32 & 16 & 28 \\
\hline Chromium, Total, mg/l $\mathrm{Cr}$ & $<.02$ & 6.02 & $<.02$ & $\angle \quad .02$ & c.. .02 & $\leq .02$ \\
\hline Shromium, llexavalent, $\mathrm{mg} / 1 \mathrm{Cr}$ & $5 \quad .02$ & $<.02$ & $\leq \quad .02$ & $<\quad .02$ & $<.02$ & $<.02$ \\
\hline Capper, mg/1 Cu & $\leq .02$ & $<\quad .02$ & $\leq .02$ & .02 & .02 & $\leq .02$ \\
\hline EDTA $m g / 1 \mathrm{Cu} e q$. & .08 & .06 & .06 & .05 & .067 & $.05 \hat{8}$ \\
\hline Iron $\mathrm{mg} / 1 \mathrm{Fe}$ & .23 & .24 & .37 & .48 & .144 & .14 \\
\hline Nirrate, mg/I $N$ & 1.3 & .46 & .6 & .84 & 1.3 & 1.3 \\
\hline 0i1 and Grease, mg/1 & .5 & $5 \quad .5$ & $5 \quad .5$ & $\leq \quad .5$ & .5 & $<.5$ \\
\hline pll & 6.40 & 6.25 & 6.55 & 6.65 & 6.95 & 6.70 \\
\hline Plospliale, Tota1, mg/1P & $<\quad .2$ & $<\quad .2$ & $\leq \quad .2$ & .2 & .2 & $<.2$ \\
\hline Phosphate, Ortho, $\mathrm{mg} / 1 \mathrm{P}$ & 5.2 & $<\quad .2$ & $5 \quad .2$ & .2 & $\because .2$ & $\leqslant .2$ \\
\hline Solids, Dissulved & 109 & 79 & 72 & 64 & 73 & 172 \\
\hline Solids, Suspended, $\mathrm{mg} / 1$ & $r$ & 1 & 5 & 4 & 27 & 1 \\
\hline 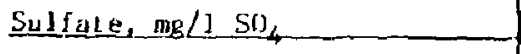 & 15 & 12 & 14 & 14 & 51.0 & 10 \\
\hline TurbidiLje N'tl & 4.0 & 3.8 & 3.4 & 2.2 & 2.6 & 1.8 \\
\hline Zinc, mu/1 $\angle n$ & .02 & .03 & .02 & .01 & .03 & .02 \\
\hline Ciarity & Clear & Clear & çlear & SI. Claudy & 51. Cloudy & Gear \\
\hline
\end{tabular}




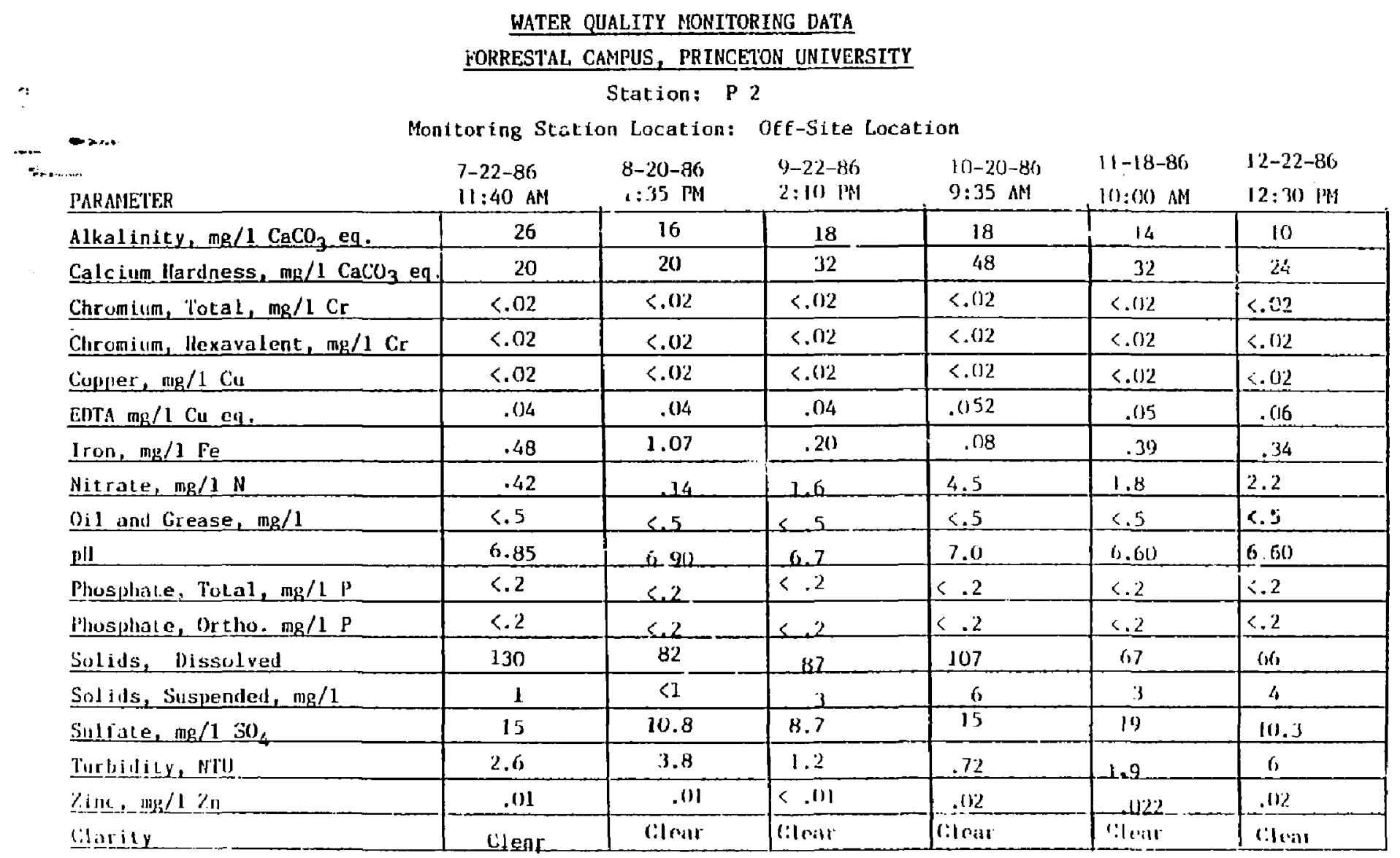


TABLE_22

WATER QUAL.ITY MONITORING DATA FORRESTAL CAMPUS, PRINCETON IJNTVERSITY

Station: $M$ J

Monitoring Station location: Millstone Rjver

\begin{tabular}{|c|c|c|c|c|c|c|}
\hline PARAMIETER & $\begin{array}{l}1-22-86 \\
5: 10 \quad P M \\
\end{array}$ & $\begin{array}{l}2-24-86 \\
1: 30 \mathrm{PM}\end{array}$ & $\begin{array}{l}3-18-86 \\
3: 20 \quad P M \\
\end{array}$ & $\begin{array}{l}4-28-86 \\
11: 00 \mathrm{MH}\end{array}$ & $\begin{array}{l}5-27-86 \\
5: 00 \mathrm{PM} \\
\end{array}$ & $\begin{array}{l}6-19-86 \\
5: 30 \quad 13 \\
\end{array}$ \\
\hline Alkalinily, $\mathrm{mg} / 1 \mathrm{CaCO}_{3} \mathrm{eq}$. & 2 & 10 & 10 & 14 & 22 & 28 \\
\hline Calc ium llardness, mag/1 $\mathrm{CaCO}_{3}$ eq. & 56 & 20 & 64 & 28 & 24 & 32 \\
\hline Chromi (m, Total, mg/1 $\mathrm{Cr}$ & $\therefore .02$ & $\leq .02$ & $\therefore .02$ & $\therefore .02$ & $\leq \quad .02$ & $\therefore .02$ \\
\hline Chrumiuln, llexavalent, mg/1 $\mathrm{cr}$ & $<.02$ & $<.02$ & $\leq .02$ & $\leq .02$ & $\therefore .02$ & $<.02$ \\
\hline Copper, $\mathrm{mg} / 1 \mathrm{Cu}$ & $<.02$ & .03 & 5.02 & $5 \quad .02$ & $\therefore .02$ & $\leq .02$ \\
\hline EDTA mg/1 Cu eq. & .08 & .08 & .06 & .05 & .062 & .056 \\
\hline Iron, $\mathrm{mg} / 1 \mathrm{Fe}$ & .24 & .95 & .82 & .92 & .38 & .36 \\
\hline Nitrate, $\mathrm{mg} / 1 \mathrm{~N}$ & 3 & 1 & .17 & .65 & .7 & 1.2 \\
\hline Dil and lirease, $\mathrm{mg} / 1$ & $\leqslant .5$ & $\leq .5$ & $\leq .5$ & $\leq \quad .5$ & $\leq .5$ & $\therefore \quad .5$ \\
\hline pll & 6.45 & 6.60 & 7.00 & 6.60 & 6.95 & 7.05 \\
\hline Phosphate, Total, mg/l p & .2 & $<.2$ & $<.2$ & $<.2$ & .2 & $\leq .2$ \\
\hline Elosphate, Ortho, mg $/ \mathrm{P}$ & $<.2$ & $\leq .2$ & 5.2 & $<.2$ & $\leq .2$ & $\leq .2$ \\
\hline Sulids, bissolved & 141 & 141 & 114 & 119 & 113 & 158 \\
\hline Sulits, Suspended, mg/1 & 3 & 33 & 9 & 1 & 21 & $<1$ \\
\hline 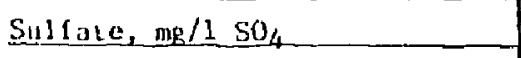 & 26 & 17 & 22 & 22 & 18 & 19 \\
\hline Iur billity. NIU & 6.9 & 13 & 8.7 & 6.3 & 4.2 & 3.9 \\
\hline Zinc & .03 & .03 & .02 &. .01 & .03 & .01 \\
\hline Clanisy & 51. Cloudy & Mod. Cloudy & Clcar & s1. Cloudy & Si. Cloudy & S1.c1) oundy \\
\hline
\end{tabular}




\section{TABI.E $22\left(\right.$ cont $\left.^{\prime} d\right)$}

WATER QUALITY MONITORING DATA FORRESTAL CAMIUUS, PRINCETON UNIVERSITY

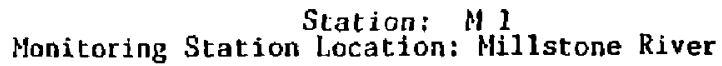

\begin{tabular}{|c|c|c|c|c|c|c|}
\hline PARAMETER & $\begin{array}{l}7-22-86 \\
12: 201 M \\
\end{array}$ & $\begin{array}{l}8-20-86 \\
1: 55 \quad 1 M \\
\end{array}$ & $\begin{array}{l}9-22-86 \\
2: 50 \mathrm{MN}\end{array}$ & $\begin{array}{l}10-20-86 \\
10: 20 \quad \mathrm{AM}\end{array}$ & $\begin{array}{l}11-18-86 \\
1(1: 40) \text { AM }\end{array}$ & $\begin{array}{l}12-22-80 \\
1: 10 \text { 忡 } \\
\end{array}$ \\
\hline Alkalinity, mg/l $\mathrm{CaCO}_{3} \mathrm{ell}_{\text {. }}$ & 24 & 22 & 24 & 20 & 20 & 12 \\
\hline Calcium llardness, $\mathrm{mg} / \mathrm{I} \mathrm{CaCO}_{3}$ eq. & 24 & 28 & 36 & 44 & 92 & 56 \\
\hline Chromium, Total $\mathrm{mg} / 1 \mathrm{Cr}$ & $\leq .02$ & $<.02$ & $<.02$ & $<.02$ & $<.02$ & $<.1) 2$ \\
\hline Chromium, Hexavalent, $m / 1 \mathrm{Cr}$ & $\leq .02$ & $<.02$ & $\leq .02$ & $<.02$ & $<.02$ & $\leq .112$ \\
\hline Copper, mg/l Cu & $\leq .02$ & $\leq .02$ & $<.02$ & $<.02$ & $<.02$ & 502 \\
\hline F.Dla mp/l Cu eq. & .04 & .04 & .03 & .061 & .106 & .05 \\
\hline Iron, mg/1 Fe & .25 & .65 & .24 & .13 & .53 & 84 \\
\hline Nitrale, mg/l $\mathrm{N}$ & .58 & $<.1$. & 1.8 & 3.1 & 1.0 & $2 \%$ \\
\hline Qi $l$ and circase, $\mathrm{mg} / 1$ & $S .5$ & $\leq .5$ & $\leq .5$ & $<.5$ & $<.5$ & $\therefore .5$ \\
\hline plll & 6.90 & 6.85 & 0.45 & 7.25 & 6.75 & 6.5 \\
\hline Phosplate, lotal, mg/l P & $\leq .2$ & .2 & .2 & $\leq .2$ & .2 & $\therefore .2$ \\
\hline Phosphiate, orcho, mg/1P & $<.2$ & $<.2$ & $\leq .2$ & $\leq .2$ & $<.2$ & $<.2$ \\
\hline Sulids, Dissolved & 159 & 92? & 129 & 104 & {$[0]$} & .87 \\
\hline Sullds, Suspended, mg/1 & $\leq 1$ & $<1$ & 4 & 4. & 4 & 16 \\
\hline Sullater ng/1 $50_{4}$ & 20 & 12.6 & 183 & 21 & 11 & 22 \\
\hline lurbidity, NIII & 3.3 & 2,8 & 2.11 & 1.1 & 4.4 & $1 / 4$ \\
\hline Zing & .03 & .02 & $<.111$ & .111 & .112 & $.11 \%$ \\
\hline (1:Hen & Eleill & cilear & LI:0i1 & Siloing & (1):i1) & Sil cromily \\
\hline
\end{tabular}


TABLE 23

WATER QUALITY MONITORING DATA

FORRESTAL CAMPUS, PRINCETON UNI VERSITY

Station: W 4 (C-site)

Monitoring Station Lacation: Underground We11

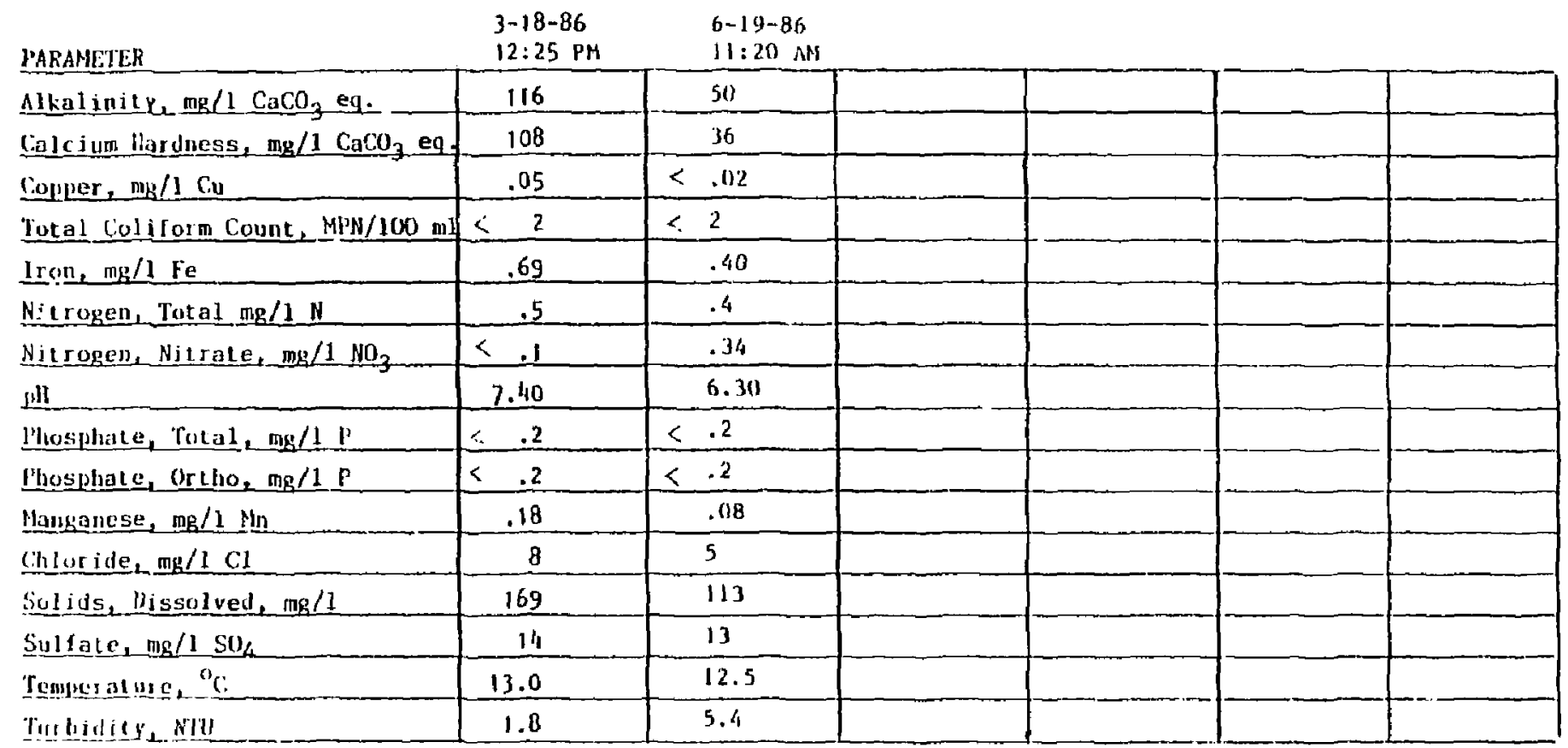


IABLE 23 (cont'd)

WA'TER QUALITY MONITORING DA'TA

FORRESIAL CAMPUS, PRINCETYN UNIVERSITY

Station: W4 (C-site)

Monitoring Station Location: Underground Well

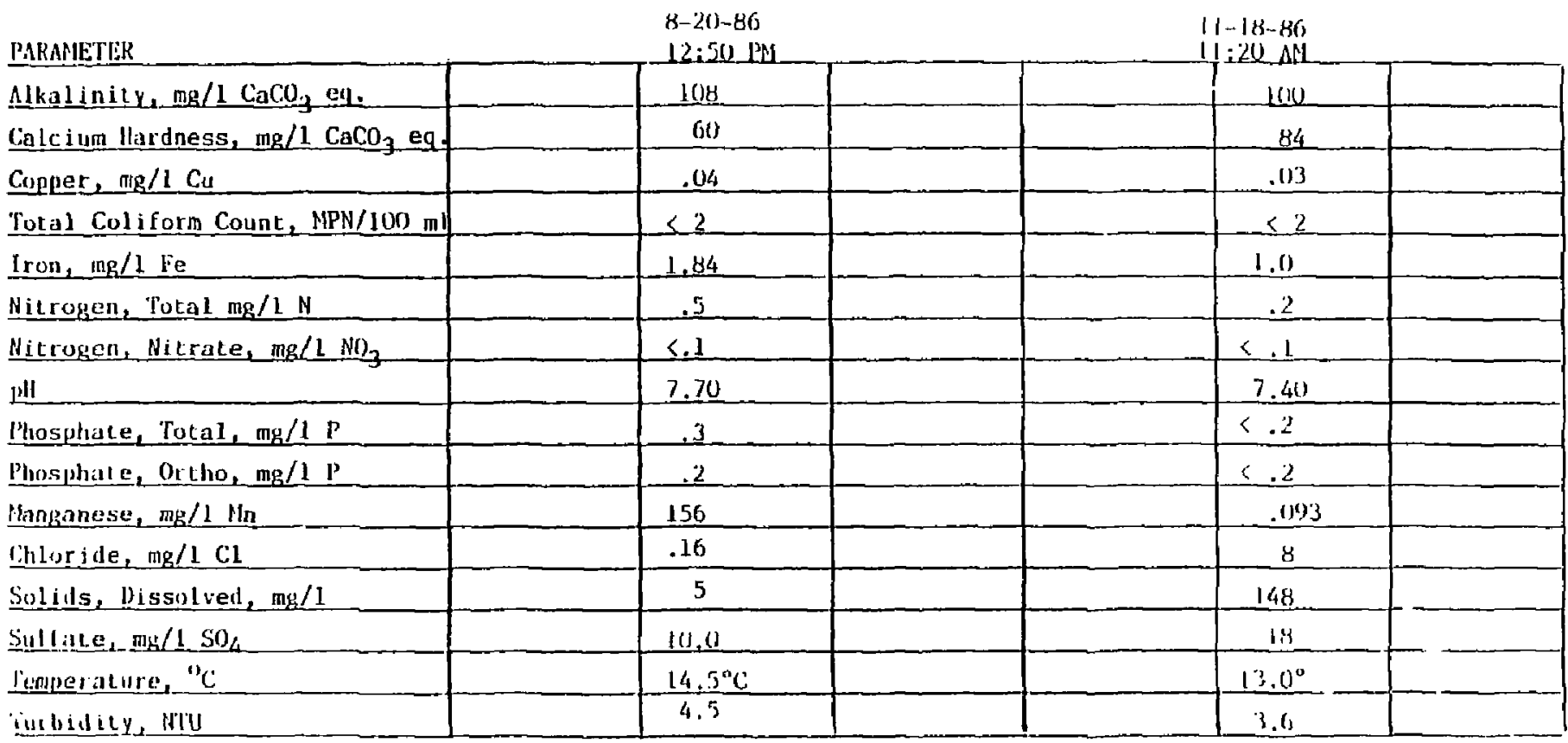


WATER OIIALITY MONITORING DATA FORRESTAL CAMPIS, PRINCEION UNIVERSITY

Stacion: H 5 (C-site)

Monitoring Station Location: Underground Well

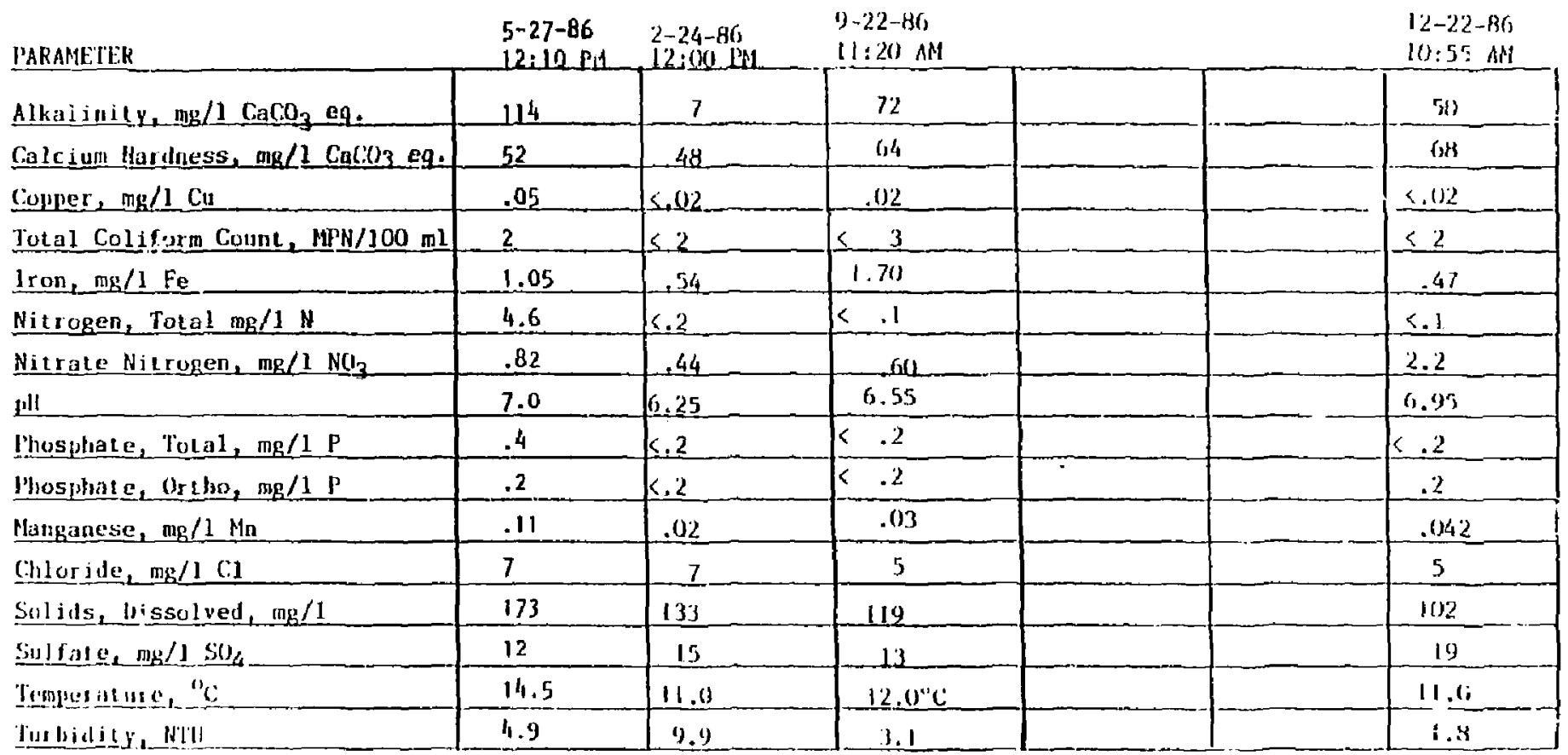


Table 25

WATER QUALITY MONITORING DATA

- FORFESTAL CAMPUS, PRINCETON UNIVERSITY

Test Well 1

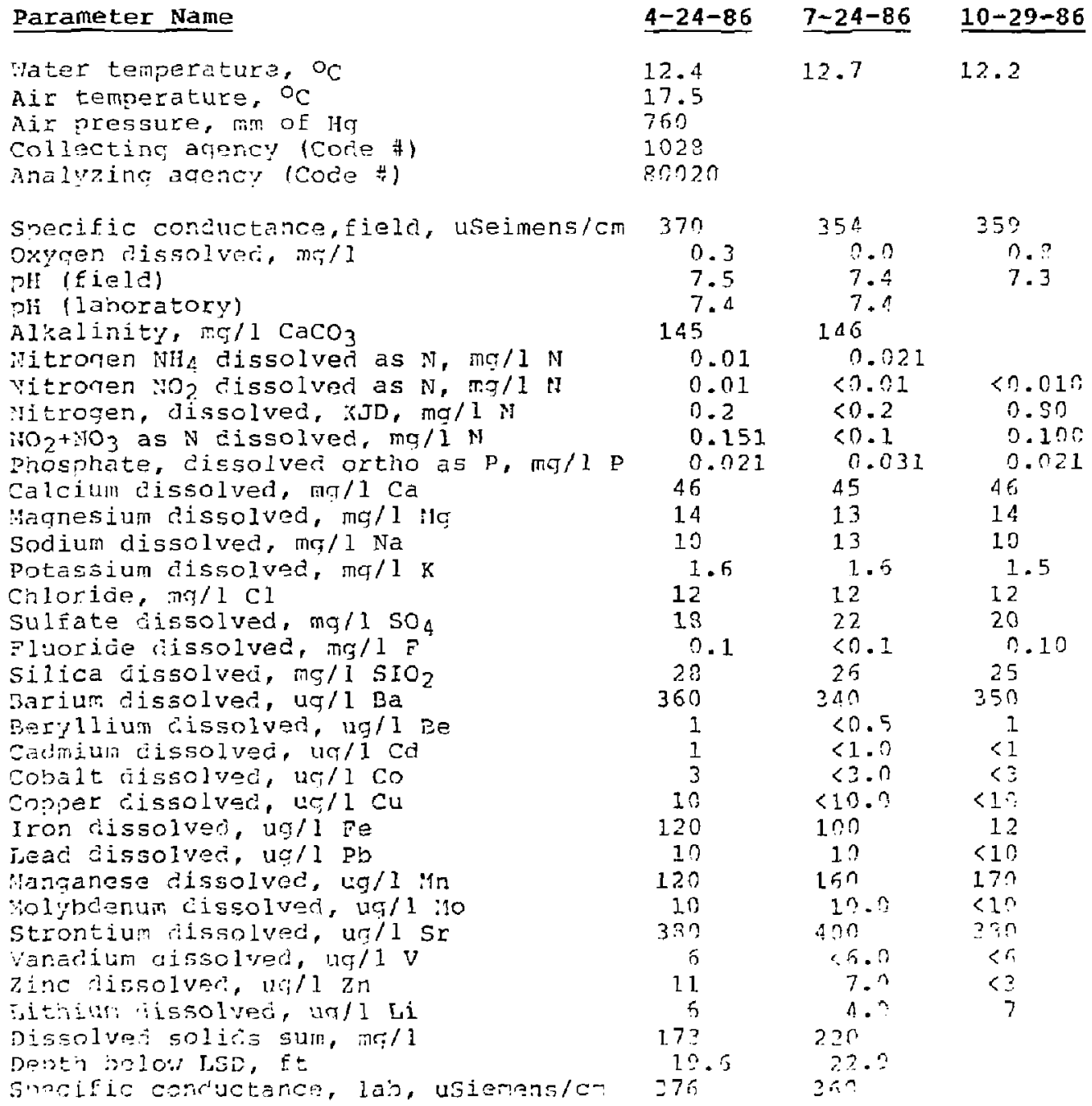


Table 26

WATER QUALITY MONITORING DATA

FORRESTAL CAMPUS, PRTNCETON UNIVERSITY

Test Well 10

\section{Parameter Name}

inater temperature, ${ }^{\circ} \mathrm{C}$

hic temperature, oc

Air prossure, $\mathrm{mm}$ of $\mathrm{Hm}$

Collectina agency (cone t)

Analyzing arancy (Cor?a

Specific conductance, field, uSeinens/cm

oxygen dissolves, ar/l

DH (fielri)

DI (laboratory)

Mlkalinity, mg/l $\mathrm{CaCO}_{3}$

Mitrogen $\mathrm{HH}_{4}$ dissolved as $\mathrm{N}, \mathrm{mg} / \mathrm{N}$

sitrogen $\mathrm{NO}_{2}$ dissolved as $\mathrm{N}$, $\mathrm{mg} / \mathrm{l}$ i

Iitrogen, dissolved, KJo, mg/l il

$\mathrm{NO}_{2}+\mathrm{NO}_{3}$ as iv aissolved, $\mathrm{mg} / \mathrm{l}$ it

Prospiate, eissolved ortho as pr mg/l $P$

Calcium dissolved, ng/I Ca

:Janesium rissolved, not/ 1 ig

Sorium dissolved, ma/l Na

Potassium dissolved, mc/l K

Chloride, $\pi r / 2 \mathrm{Cl}$

Sulfate dissolver, ma! I $\mathrm{SO}_{4}$

Fluoride dissolved, nail $F$

Silica dissolved, $\mathrm{ng} / \mathrm{l} \mathrm{SlO}_{2}$

Bariuni aissolver, ua/l Ba

3eryllitin dissolved, ur/l Be

Candin cissolver, ur/l $\mathrm{Cd}$

Cobalt dissolved, uril $\mathrm{Co}$

Copper dissolved, ua/l Cu

Iron dissolveri, urll Fe

Leac tissolved, uq/l Pb

:anganeso inissolver, u/l wh

Molobenum aissolved, tu/l :10

Strontiug dissolver, ug/l $\mathrm{sr}$

"anaritum hissolver, $u t_{1} / \mathrm{V}$

zisc rijssolve.1, 19/l 2 n

Hitidu risgolvor, ug/l Li

Disanlvari solids sum, T\&/1

Dovt: : solow ESD, Et

sanaific zonductance, lai, usiemens/cin
$4-24-86$

$7-24-86$

12.9

17.5

750

1028

30020

350

0.3

7.6

7.6

145

0.05

0.01

0.2

0.1

0.021

45

12

9.7

1.7

11

15

0.1

27

390

0. 5

1.

3

10

370

10

290

10

410

5

3

211

$1 ? .6$

$35 ?$

$\begin{array}{rr}365 & 307 \\ 0.1 & 2.5 \\ 7.4 & 7.5 \\ 7.5 & \end{array}$

142

0.041

$<0.01$

$<0.2$

$<0.1$

0.022

43

11

9.6

1.7

11

19

0.1

26

410

<0. 5

$<3$

$<10$

390

$<10$

32 ?

$<10$

420

$<5$

7

30

$2 \mathrm{ln}$

22.2

310
$10-29-86$

$12 . n$

$<0.017$

0. 4 .

0.100

ก.ก21

46

12

9.7

1.6

12

17

2.30

25

3.30

1

$<1$

$<10$

519

$61 \mathrm{i}$

30 .

$<19$

410

$<5$

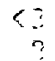


TABLE 27

NONRADIOACTIVE OA RESULTS (SPLIT SAMPLES)

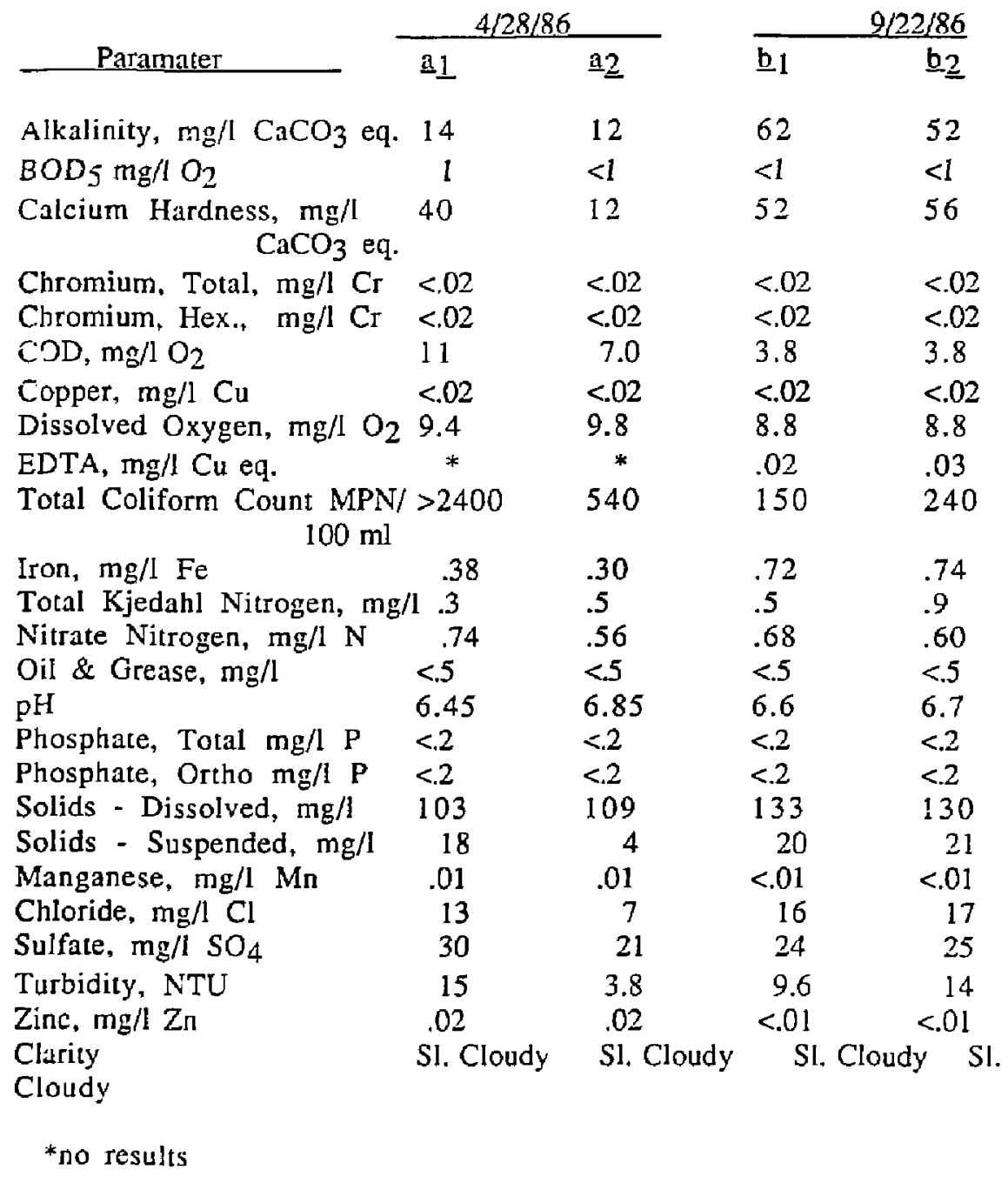


TABLE 28

QAOCEPA LAS VEGAS: 1 -OSS-CHECK PROGRAM 1986

\begin{tabular}{|c|c|c|c|}
\hline $\begin{array}{l}\text { SAMPLE } \\
\text { DATE_ }\end{array}$ & $\begin{array}{l}\text { TYPE } \\
\text { SAMPLE }\end{array}$ & $\begin{array}{l}\text { KNOWN VALUES } \\
\text { HTO CONCENTRAT!ON (pCi//) PLUS } \\
\text { EXPECTED LAB PRECISION }\end{array}$ & $\begin{array}{l}\text { PPPL } \\
{ }^{r} \mathrm{ALUES} \\
\text { (DCi/l) }\end{array}$ \\
\hline $4 / 25 / 86$ & Urine & $4423+1 \cdot 442$ & $\begin{array}{l}4560 \\
4380 \\
4340\end{array}$ \\
\hline $6 / 13 / 86$ & Water & $3,25+1-360$ & $\begin{array}{l}2880 \\
2920 \\
2980\end{array}$ \\
\hline $11 / 7 / 86$ & Urine & $5257+/ \cdot 526$ & $\begin{array}{l}5190 \\
5040 \\
5300\end{array}$ \\
\hline
\end{tabular}


TABLE 29

FERTILIZEK, PESTICIDES, AND HERBICIDE APPLICATION (Cl87)

\section{FERTILIZER}

A Site

B Site

C Site

D Site

\section{PESTICIDES}
A Site
B Site
C Site
D Site

(Applied by University)

$10-6-4 \quad 50 \%$ Organic
1000 Jbs.

1800 lbs.

1200 lbs.

1000 lbs.

\section{HERBICIDES}

\begin{tabular}{|c|c|c|c|}
\hline DATE & LOCATTON & PRODUCT & AMOUNT \\
\hline $4 / 12 / 86$ & C-Site & Balan (Pro Lawn) & $500 \mathrm{lbs}$. \\
\hline $6 / 5 / 86$ & $\begin{array}{l}\text { TFTR Electrical } \\
\text { Yards \& Sub }\end{array}$ & Arsenal (Cyanamid) & $\begin{array}{l}6 \mathrm{pts} \text { in } 300 \\
\text { gal. of water }\end{array}$ \\
\hline $6 / 6 / 86$ & $\begin{array}{l}\text { A\&B Electrical } \\
\text { Subs }\end{array}$ & Arsenal (Cyanamid) & $\begin{array}{l}6 \text { pls in } 300 \\
\text { gal. of water }\end{array}$ \\
\hline $6 / 14 / 86$ & $\begin{array}{l}\text { C-Site } \\
\text { D-Site }\end{array}$ & $\begin{array}{l}\text { Spike 80W (Pocono Turf) } \\
\text { Spike } 80 \mathrm{~W} \text { (Pocono Turf) }\end{array}$ & $\begin{array}{l}10 \mathrm{lbs} . \\
10 \mathrm{lbs} .\end{array}$ \\
\hline $6 / 27 / 86$ & $\begin{array}{l}\text { C-Sit } \text { Receiving } \\
\text { Yard }\end{array}$ & Arsenal (Cyanamid) & $\begin{array}{l}2 \text { pts in } 100 \\
\text { gal. of water }\end{array}$ \\
\hline $7 / 1 / 86$ & $\begin{array}{l}\text { Canal Water } \\
\text { Pump House }\end{array}$ & Arsenal (Cyanamid) & $\begin{array}{l}0.7 \mathrm{pts} \text { in } 35 \\
\text { gal. of water }\end{array}$ \\
\hline $9 / 9 / 86$ & C-Site & $\begin{array}{l}\text { Spike 80W (Pocono Turf) } \\
\text { Roundup (C\&B) } \\
\text { Princep Caliber } 90 \text { (RFB Co) }\end{array}$ & $\begin{array}{l}10 \mathrm{lbs} . \\
2.25 \mathrm{gal} . \\
10 \mathrm{lbs} .\end{array}$ \\
\hline
\end{tabular}
No pesticides applied
No pesticides applied
No pesticides applied
No pesticides applied
(Applied by University) 


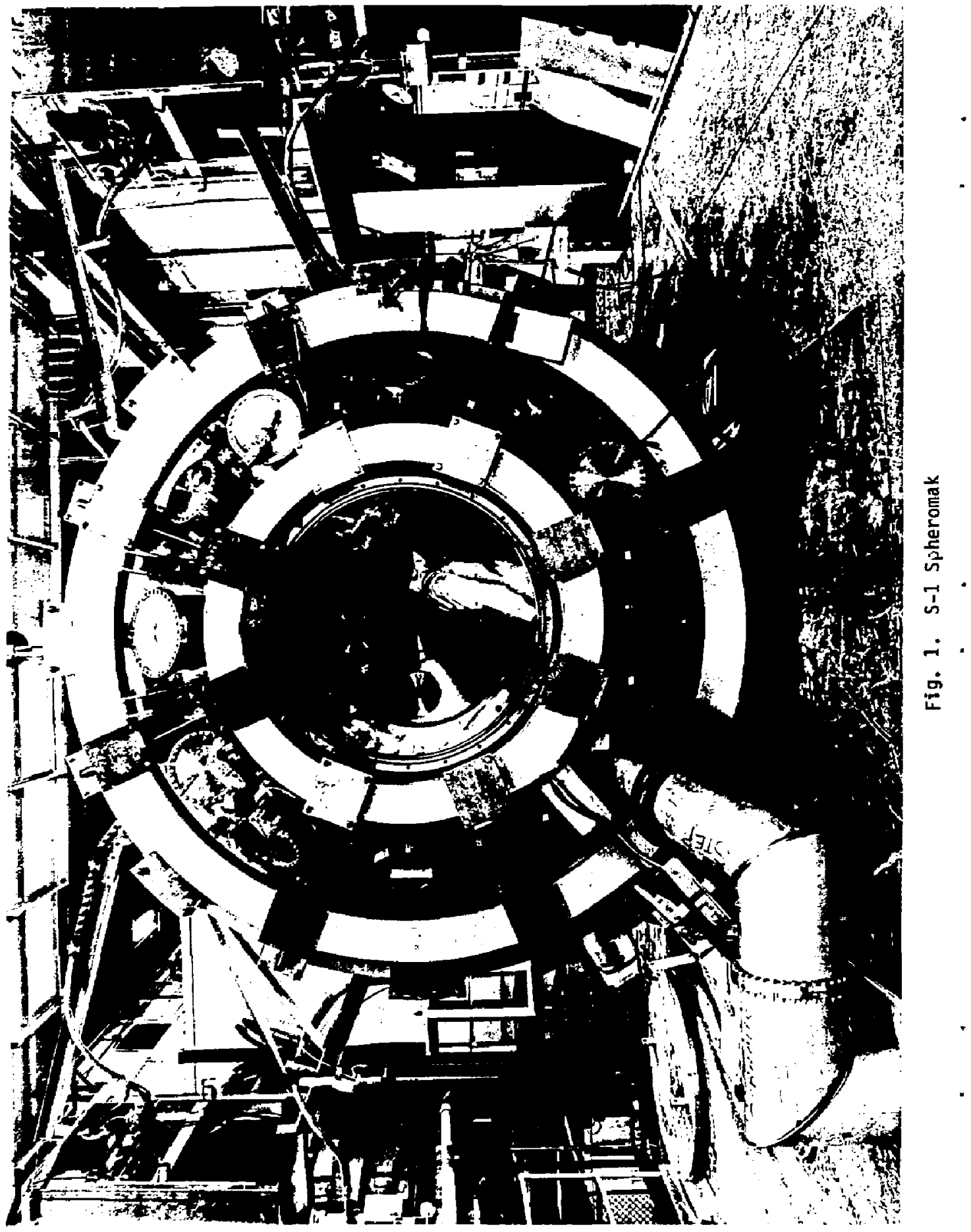




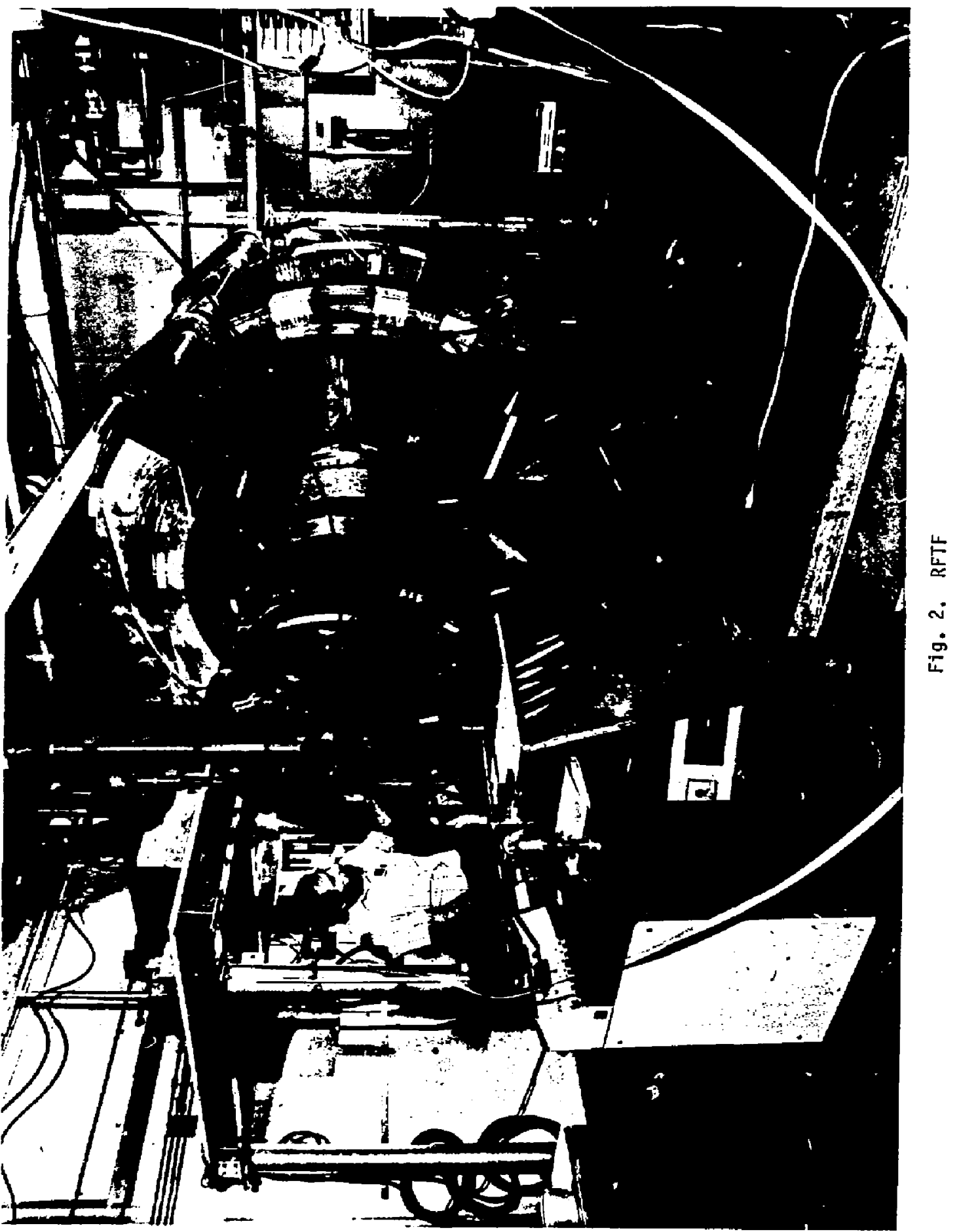




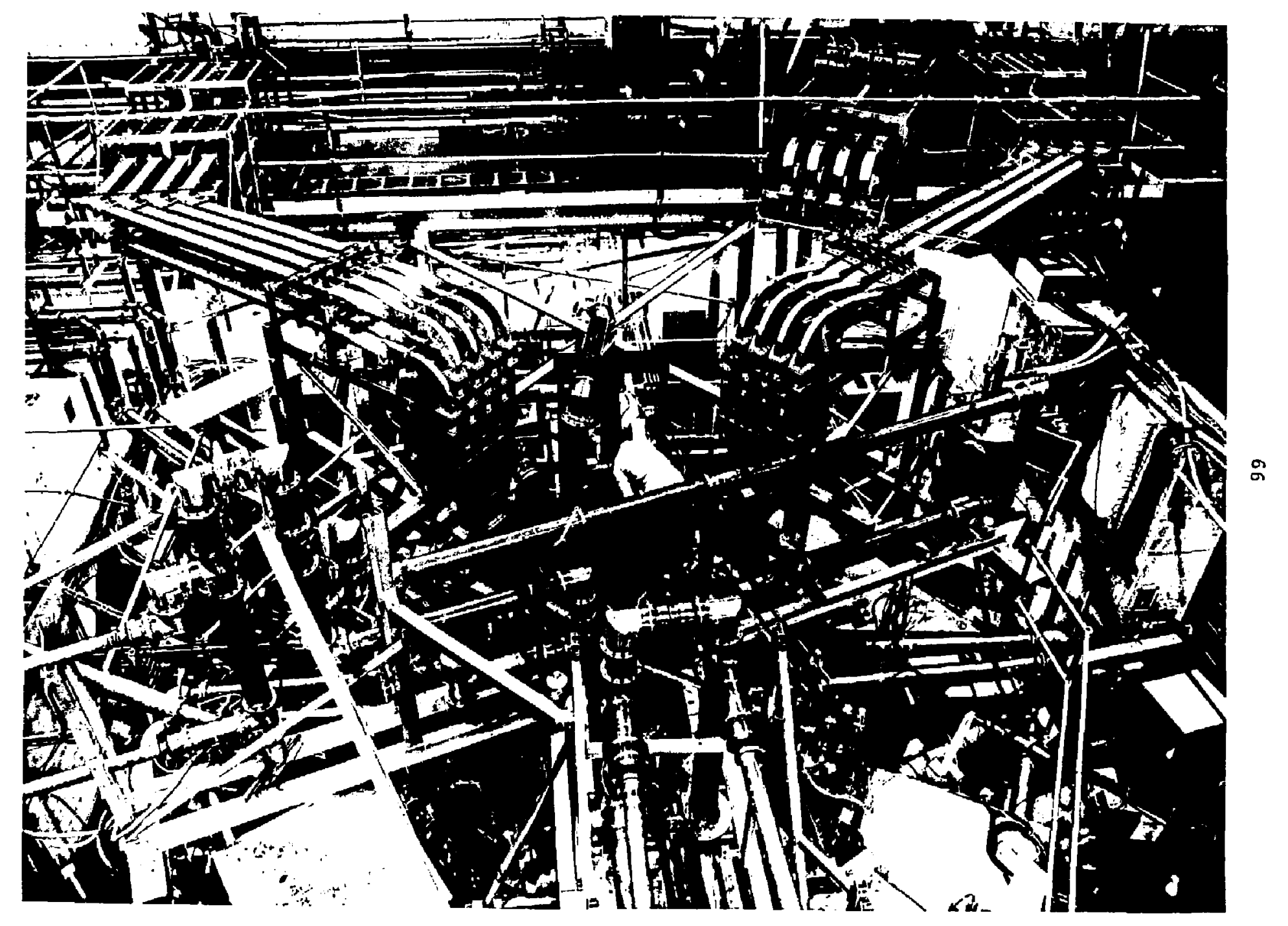

Fig. 3. Princeton Large Torus (PLT) 


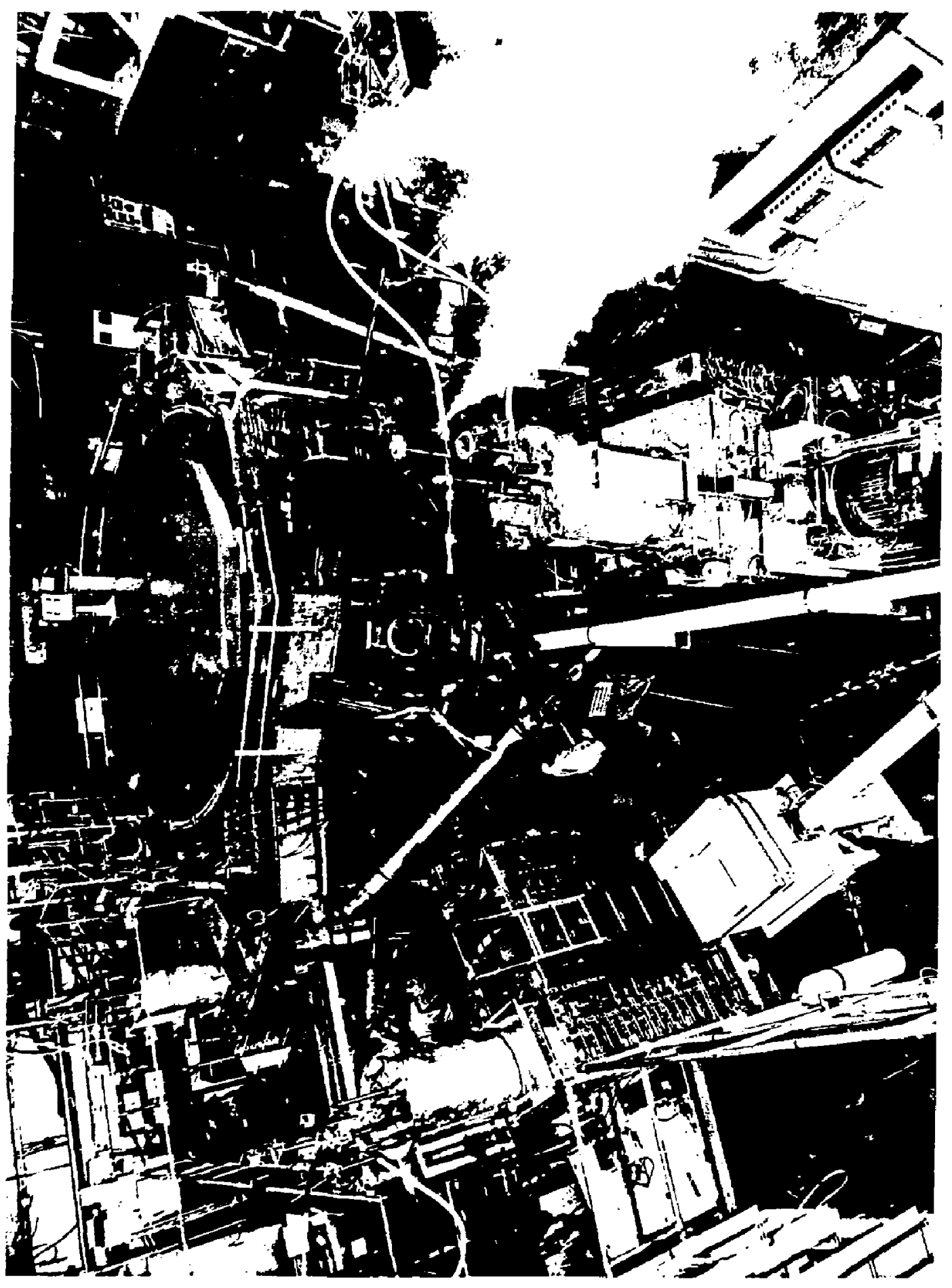




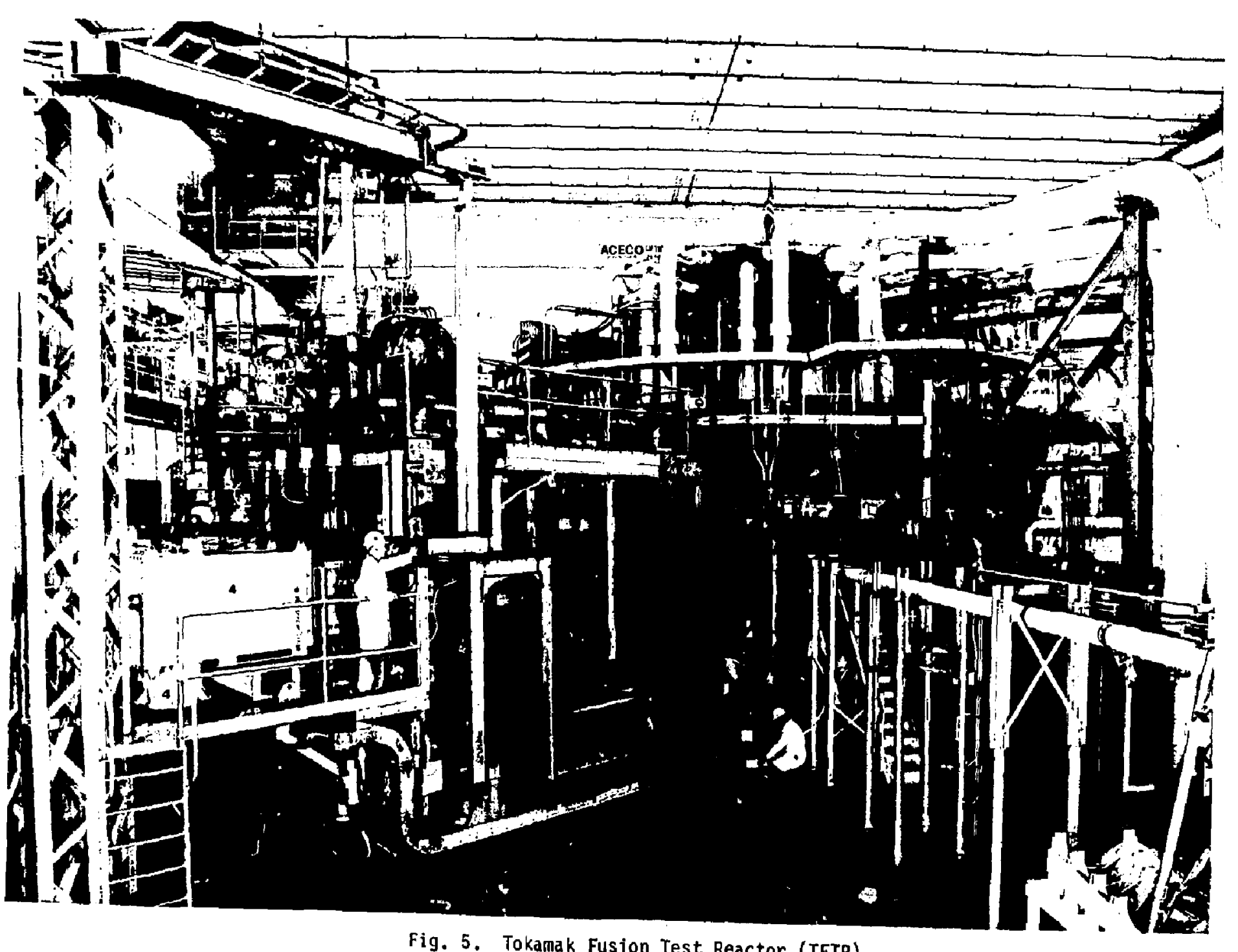

Fig. 5. Tokamak Fusion Test Reactor (TFTR) 
Wind Rose

Joint Frequency Data for TFTR $84 / 1$ to $86 / 12$

Elevation $30 \mathrm{~m}$

For All Stability Classes $(100.0 \%)$

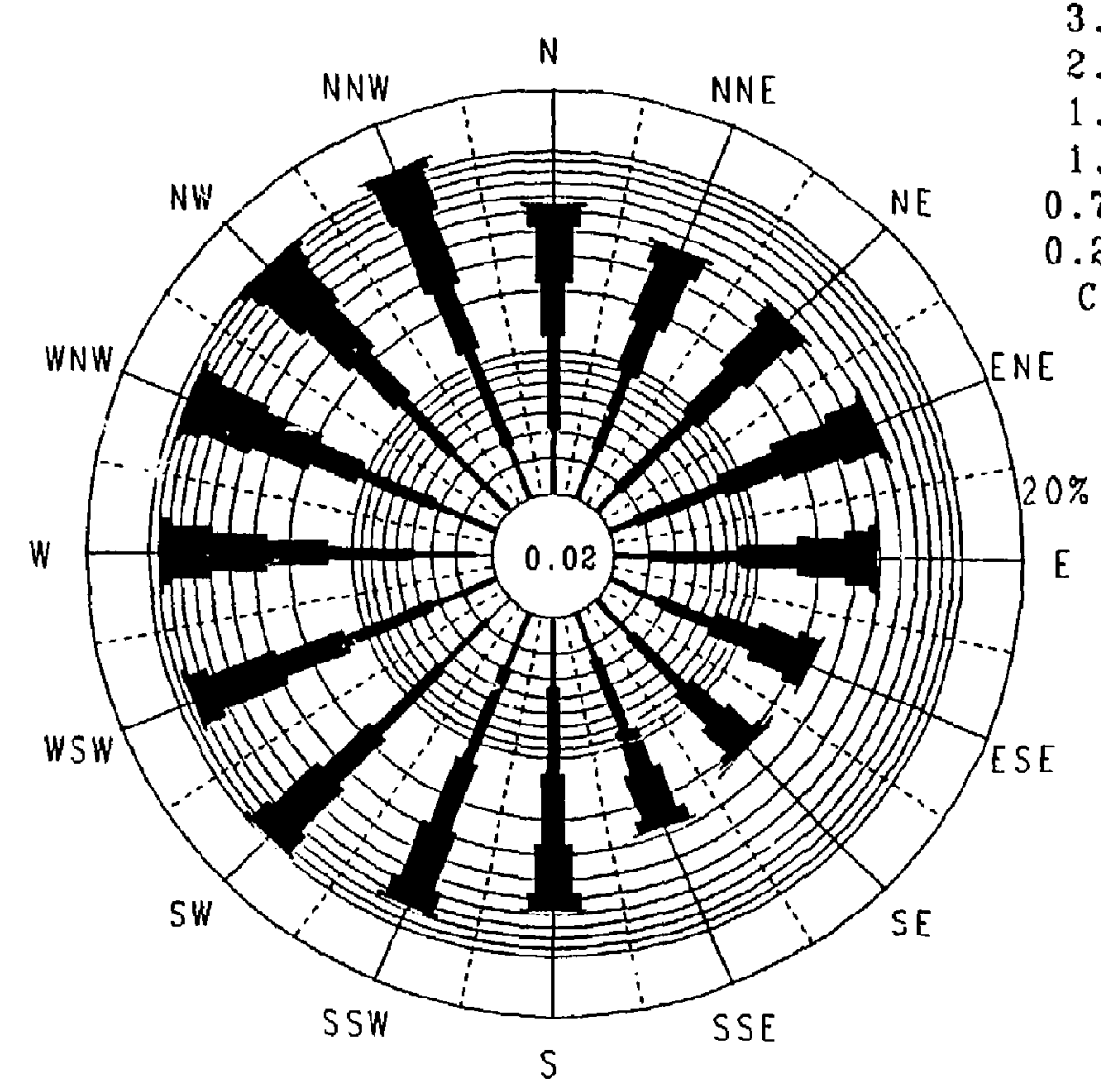

Wind Speed $(\mathrm{m} / \mathrm{s})$

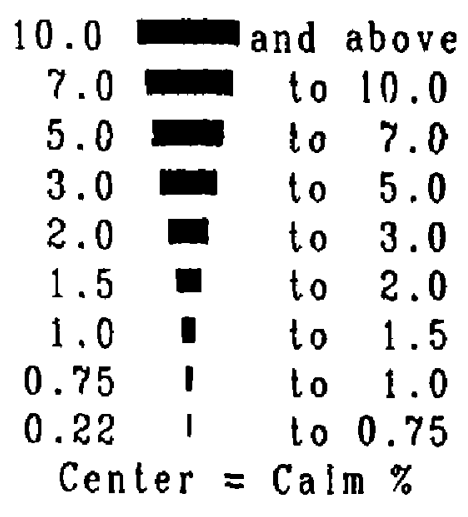




\section{$84 / 1$ to $86 / 12$ \\ Elevation $60 \mathrm{~m}$}

Joini Frequency Data for TFTR

For All Stability Classes (100.0\%)

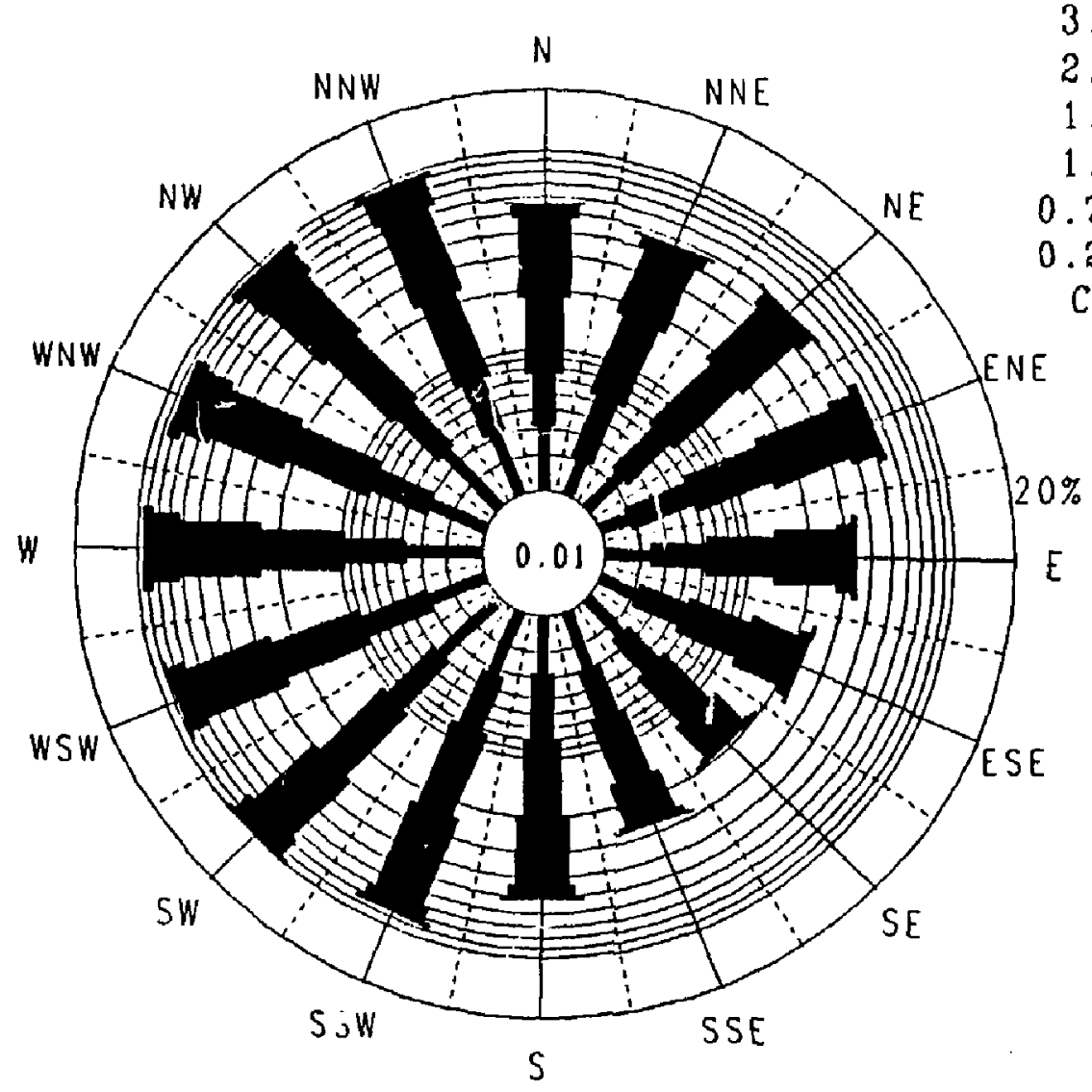

Wind Speed (m/s)

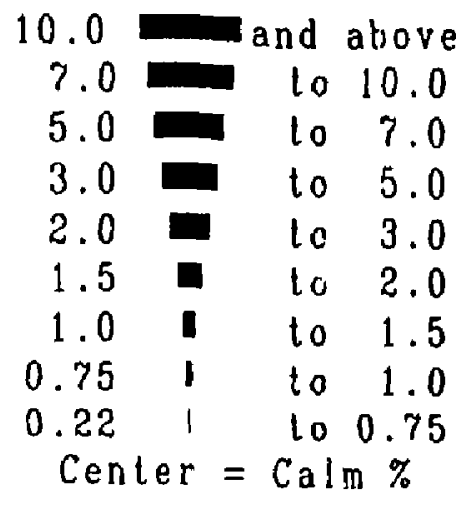




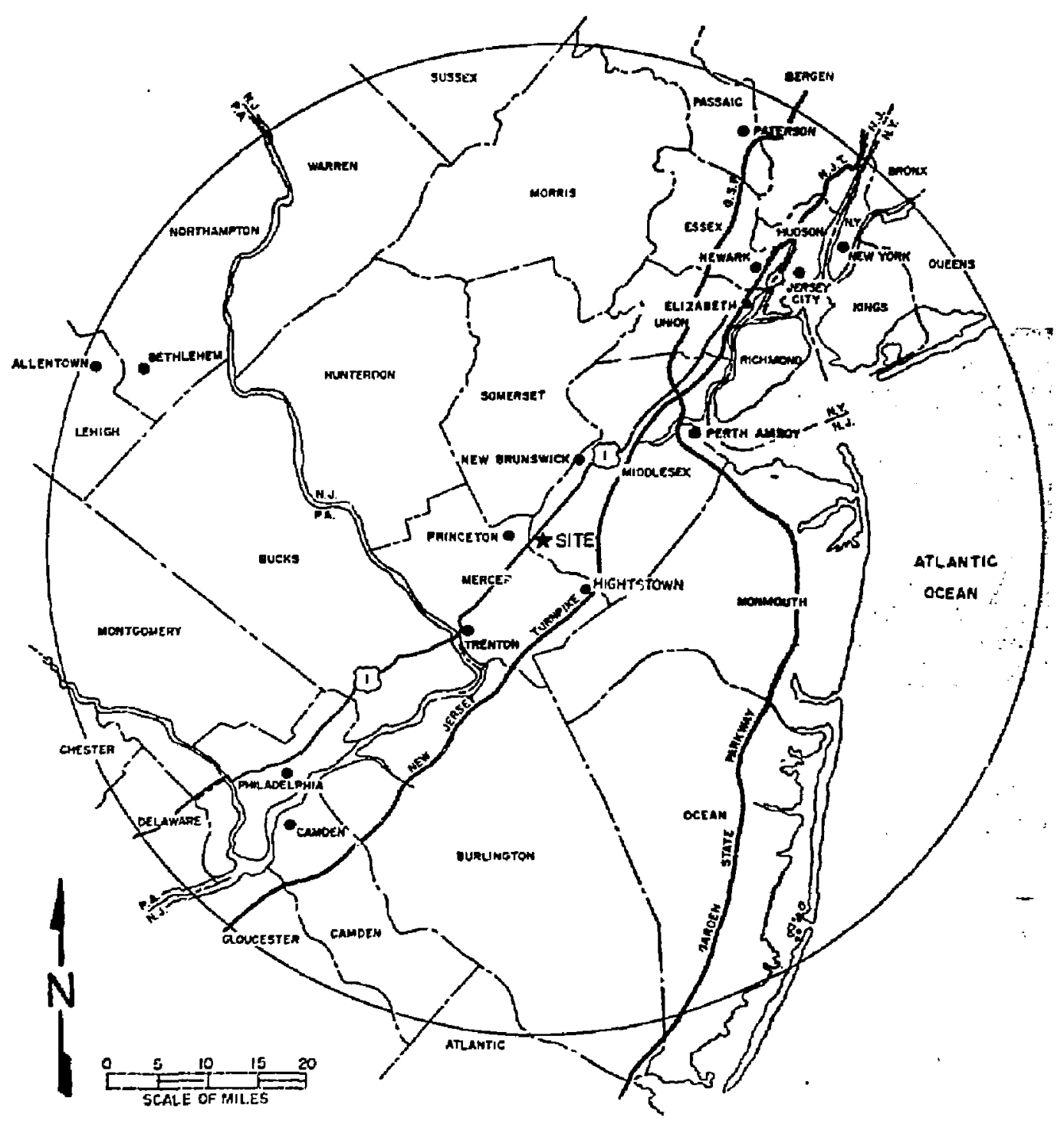

FIG. 8

$80 \mathrm{~km}$ (50.MILE) RADIUS OF SITE 


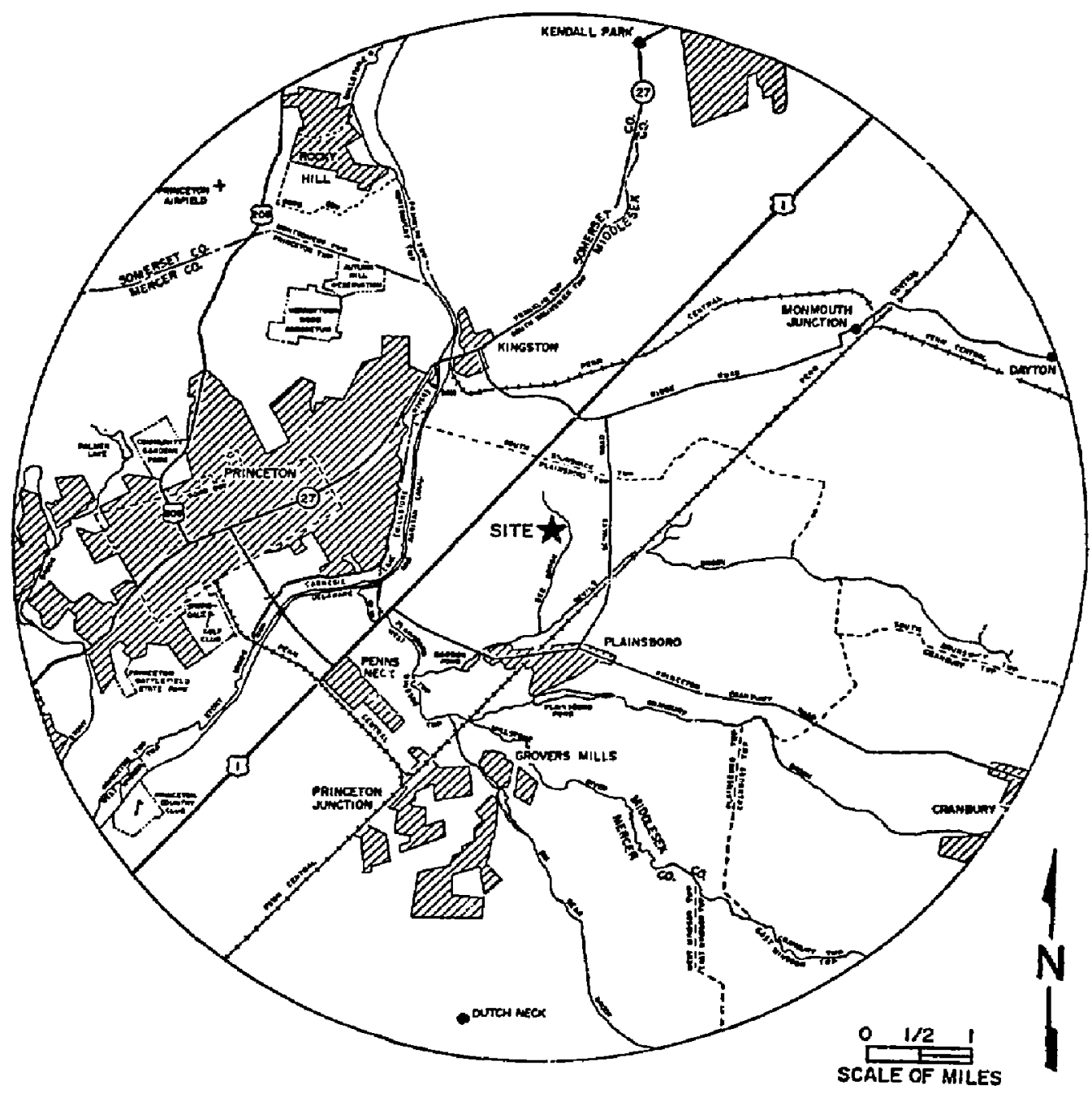

FIG. 9 


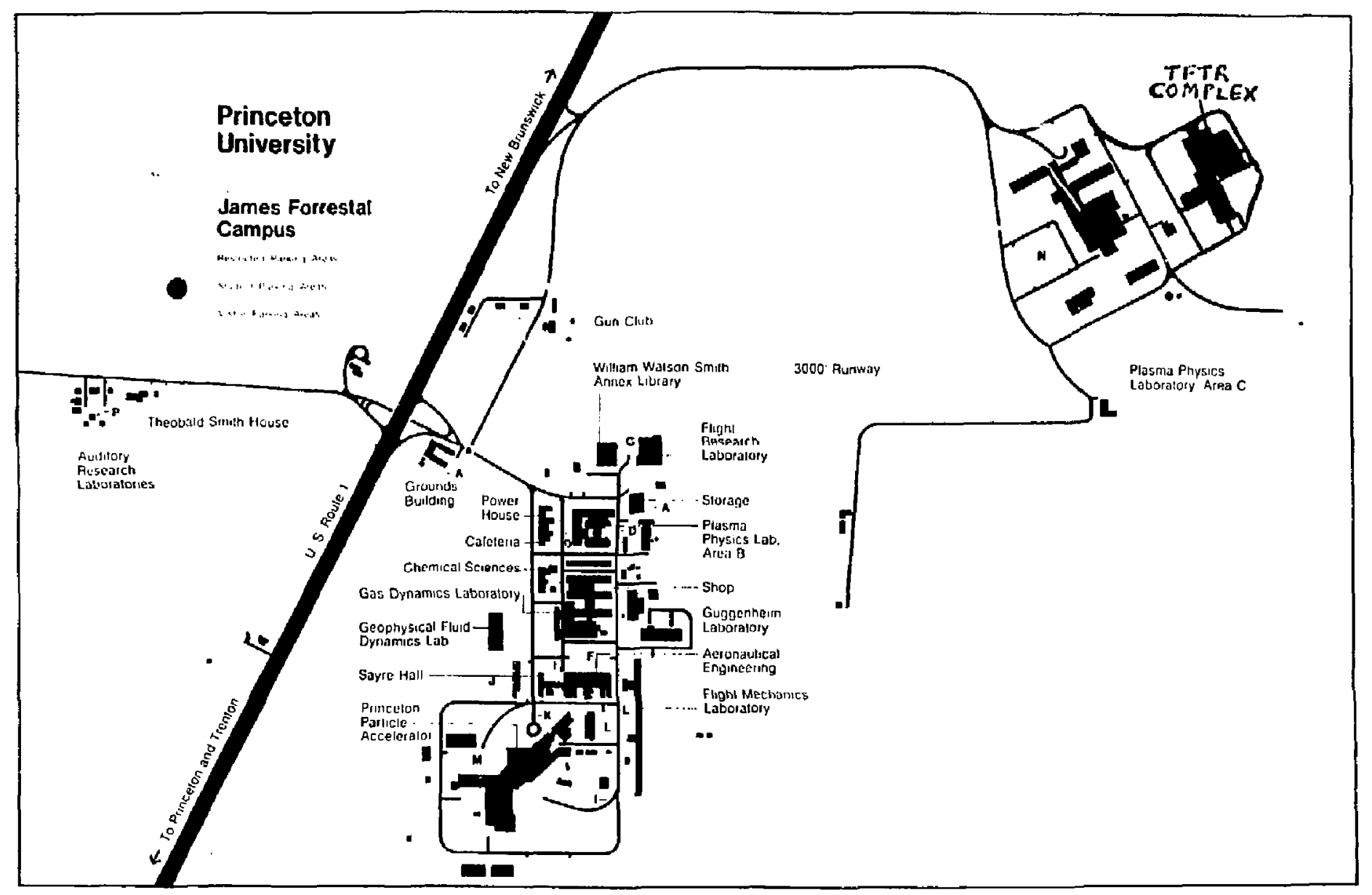

Fig. 10.

Plasma Physics Laboratory

James Forrestal Canipus

Princeton University, Princeton, NJ 


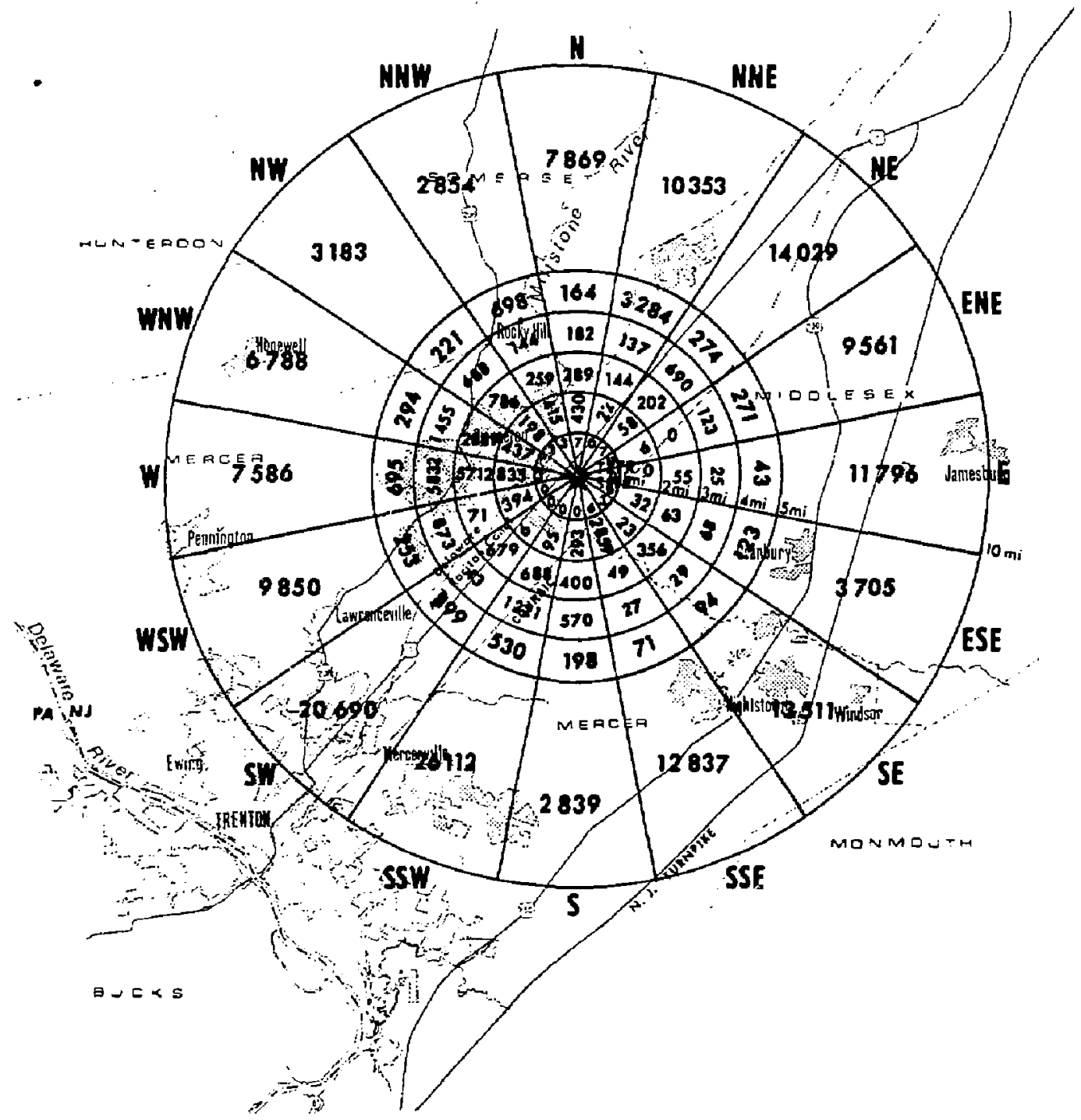

FIG. 11

1974 POPULATION ESTIMATES WITHIN ANNULAR SECTORS 0-10 MILES* 


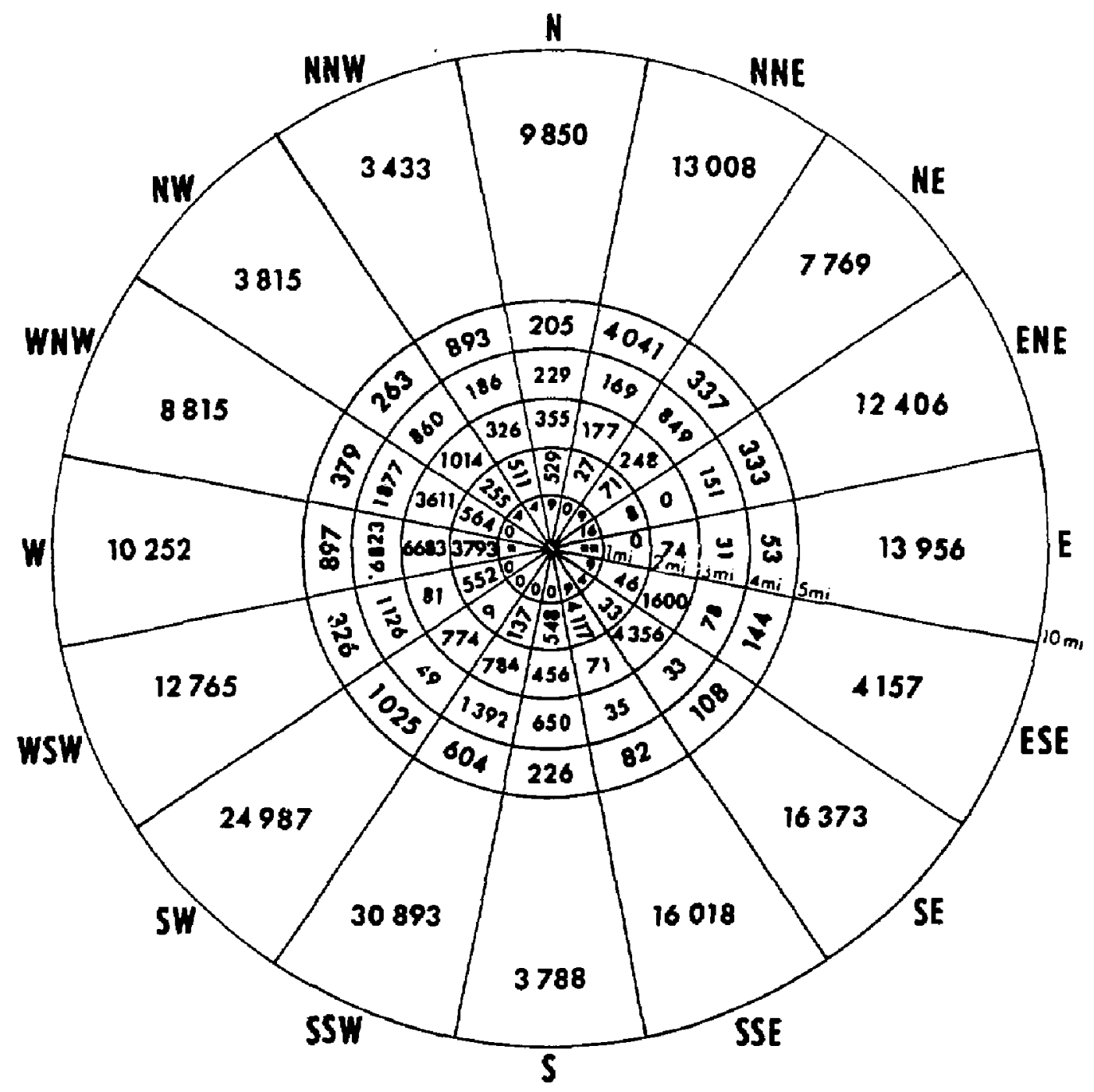

FIG. 12

1985 POPULATION ESTIMATES WITHIN ANMUAL SECTION 0-10 MILES*

*Taken from TFTR/FSAR

Fjgure 2.1.2-3 


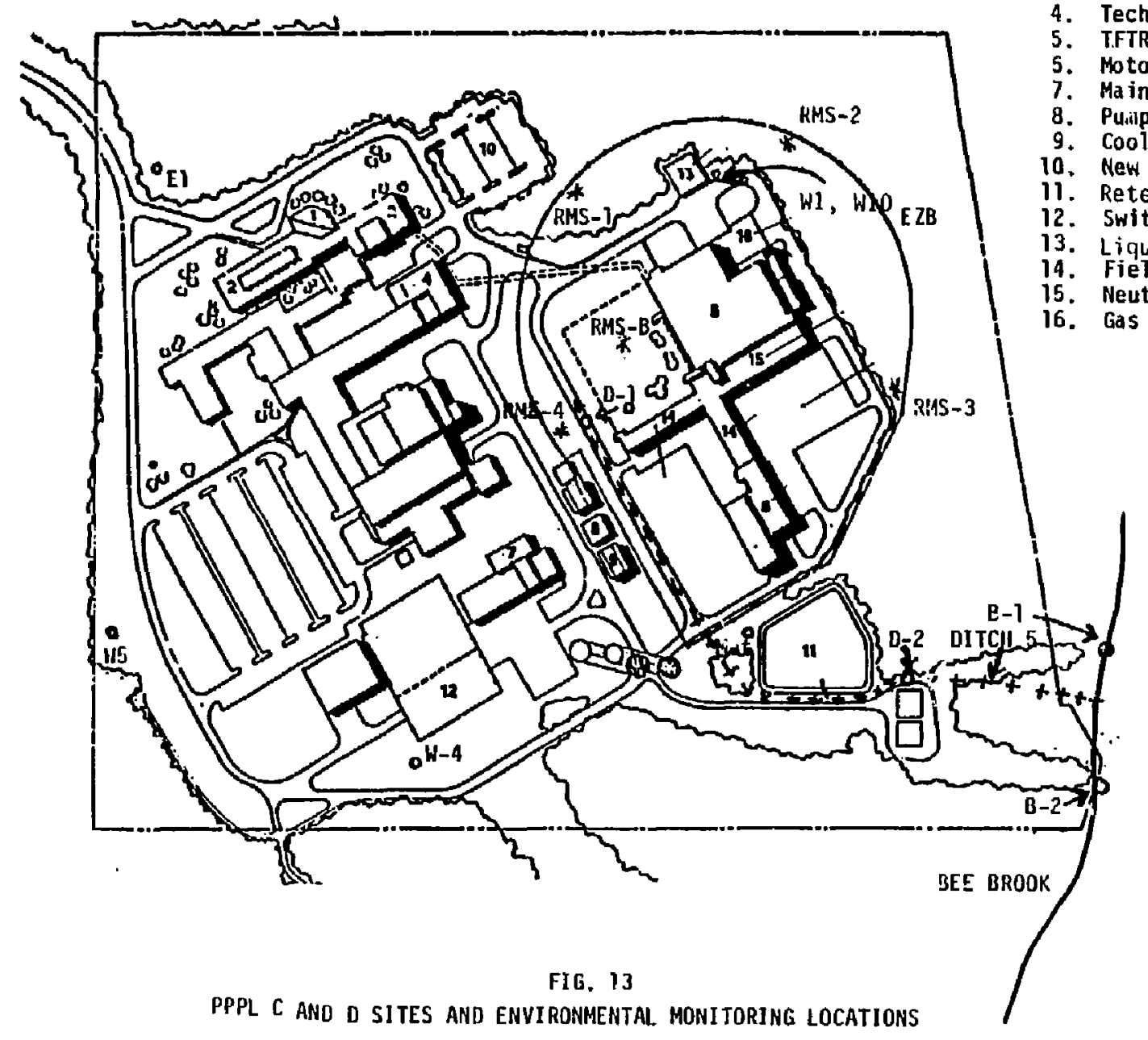

W1, W10 New D-site wells

EZB Exclusion Zone Boundary Fence

RMS-B Baseline Radiation Monitoring Station \& 01d Meteoralogical Tower

RMS-1 Radiation Monitoring Station

RH5-3 H

RMS -4 "

D-1

Ditch 5 Surface Hater Sample Location

D-2 Ditch 5 Surface Hater Sample Location

B-1 Bee Brook Surface Water Sample Location

B-2 Bee Brook Surface Water Sample Location

MET Meteorolunical Tower

E-1 Elizabethtown Sample Location

W-4 Well 44 (C-site) 

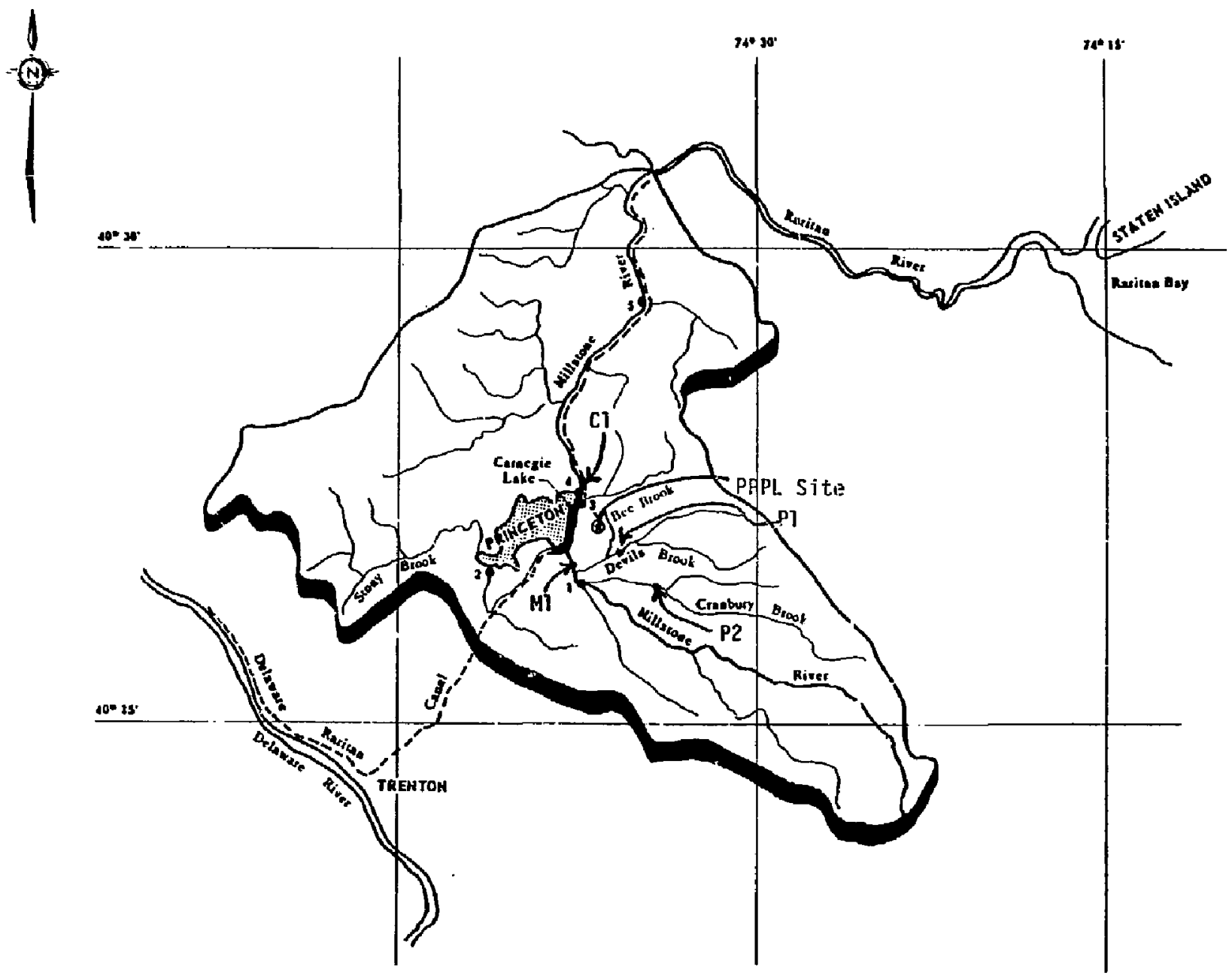

$\checkmark$

FIG. 14
MILLSTONE RIVER BASIN OFFSITE HATER SAMPLE LOCATION 


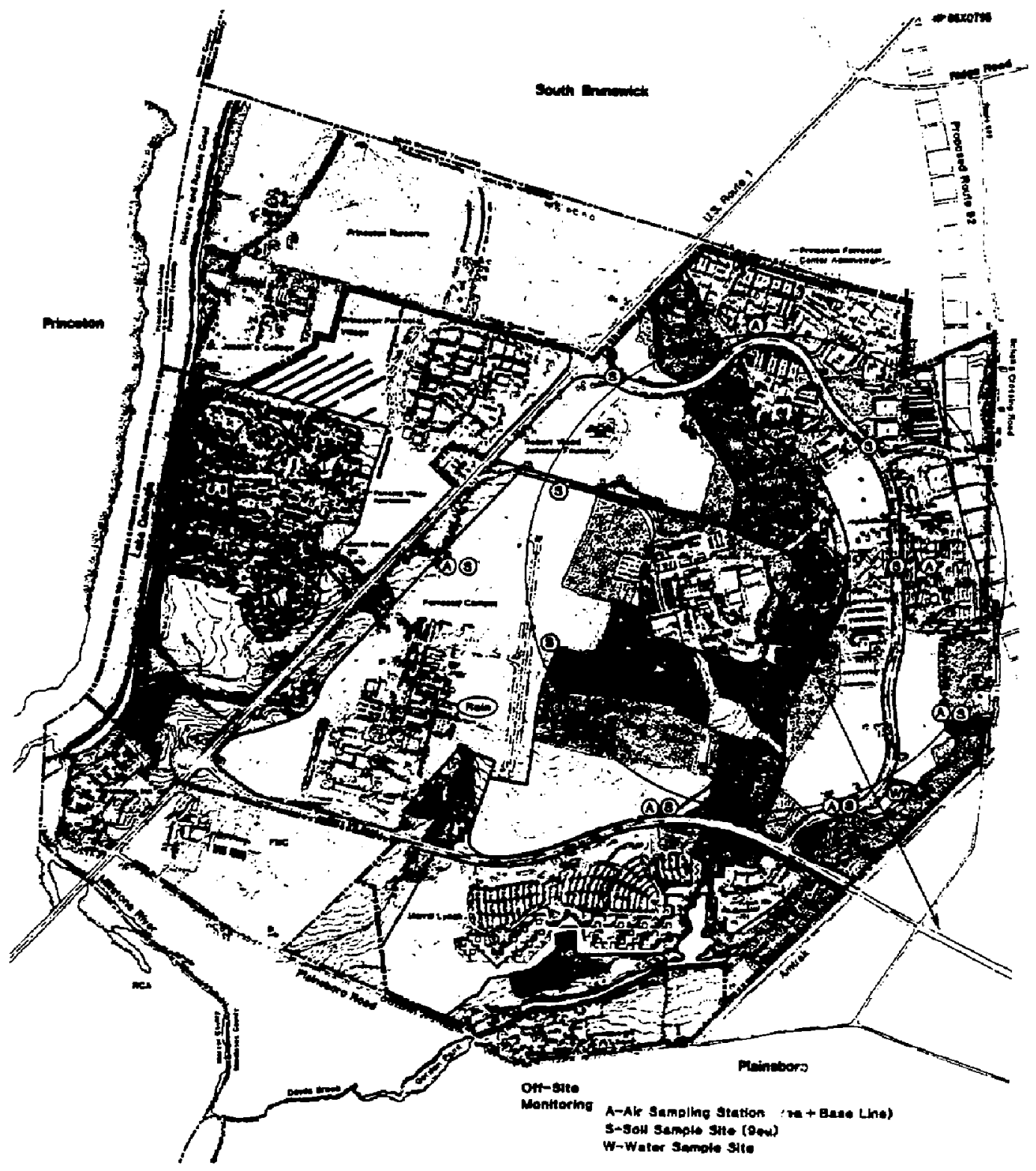

FIG. 15

PLANNEO OFF-SITE MONITORING LOCATIONS 